
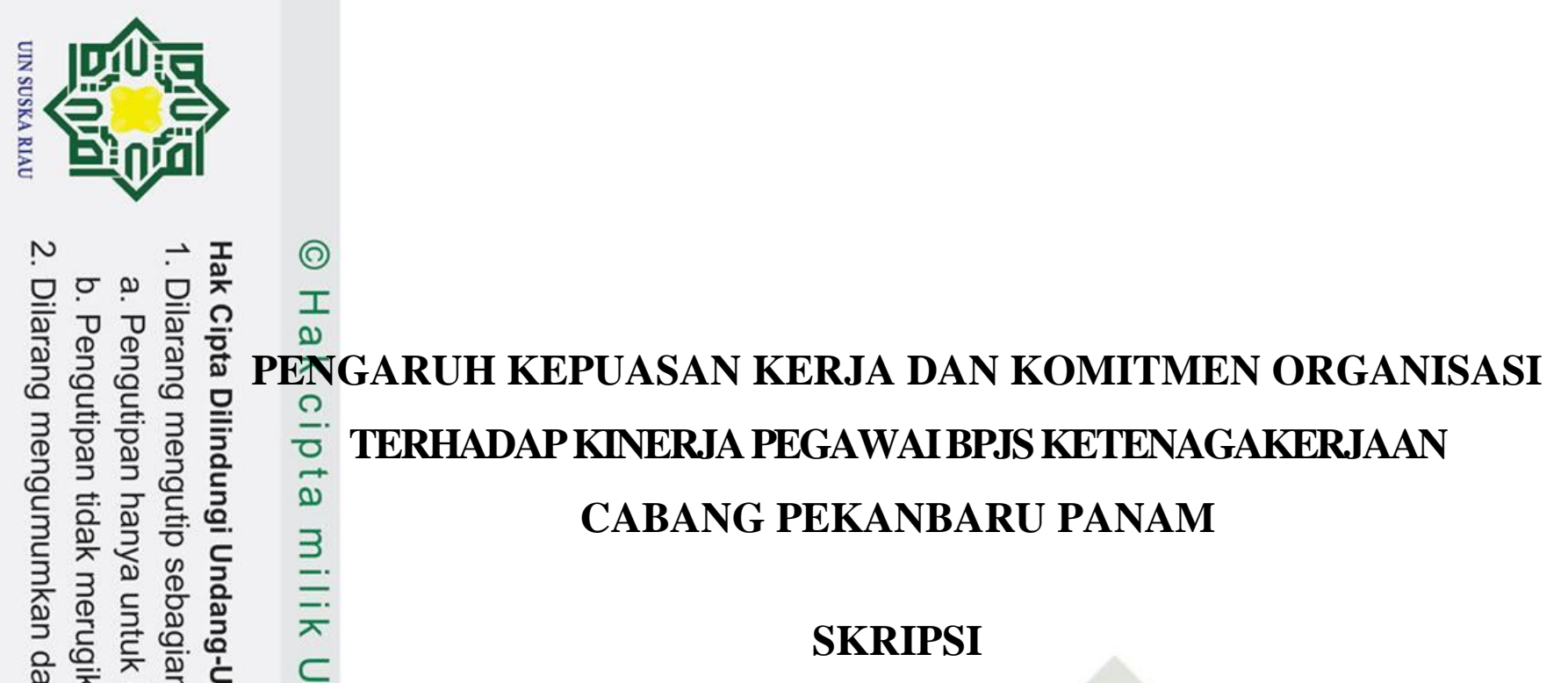

Diajukan Sebagai Salah Satu Syarat Guna Memperoleh Gelar Sarjana Ekonomi Pada Fakultas Ekonomi dan Ilmu Sosial Universitas Islam Negeri Sultan Syarif Kasim Riau

\title{
OLEH
}

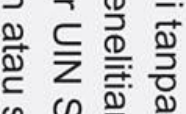

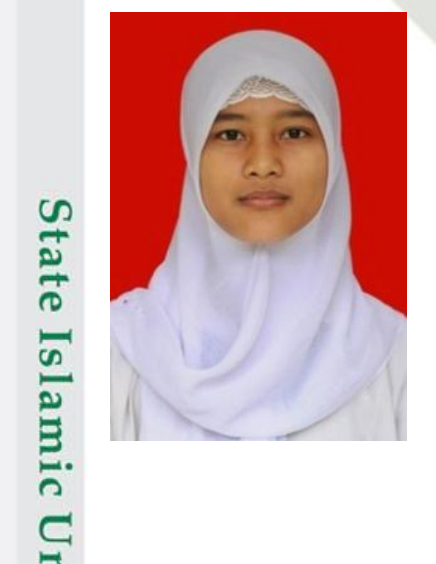

\section{ISNAH MAULINA}

NIM. 11571204777

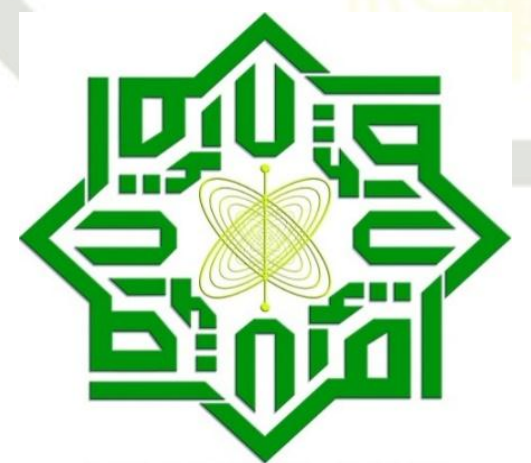

UIN SUSKA RIAU

KONSENTRASI MANAJEMEN SUMBER DAYA MANUSIA क.

PROGRAM STUDI MANAJEMEN S1

$\stackrel{\circ}{\circ}$ 

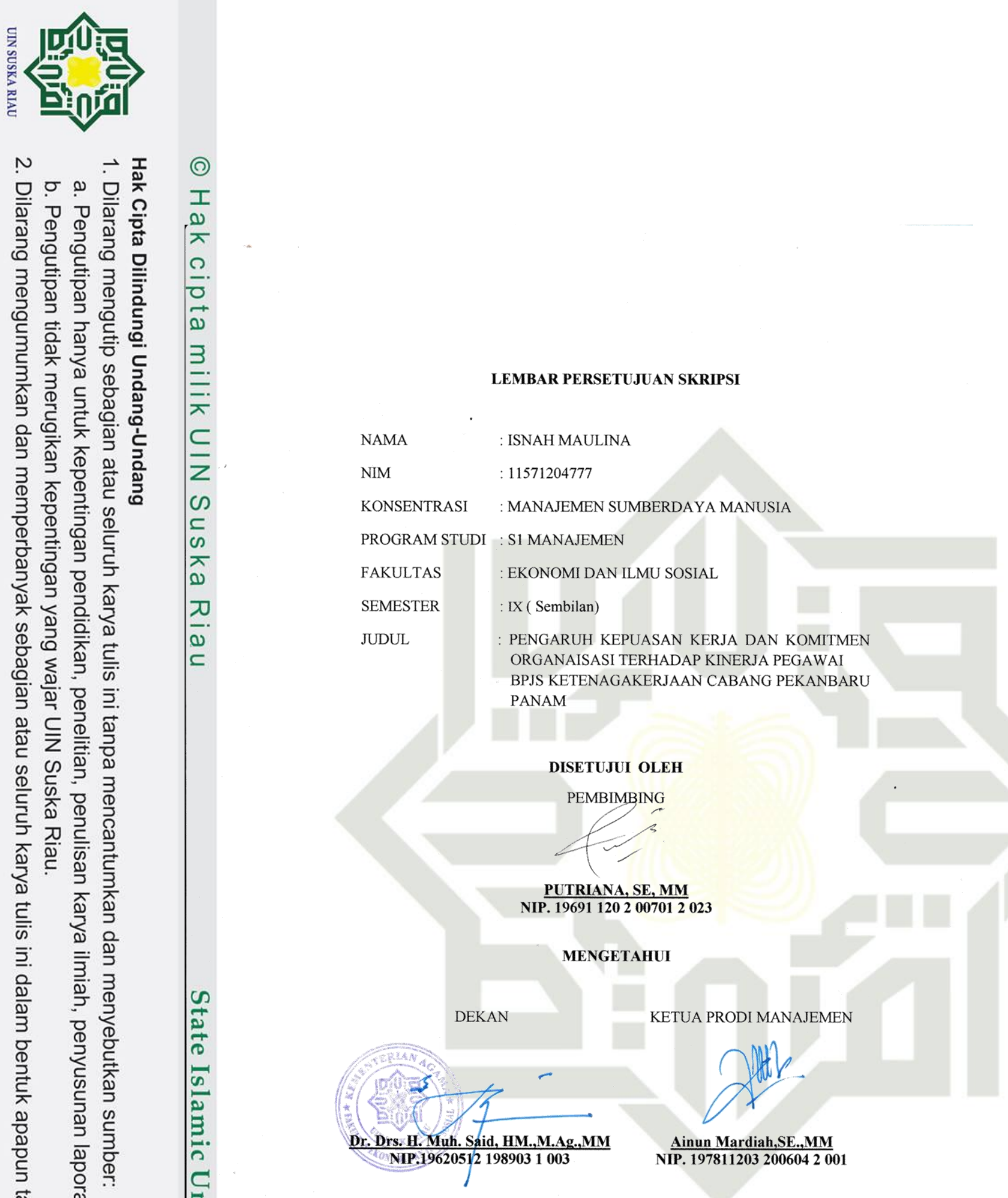

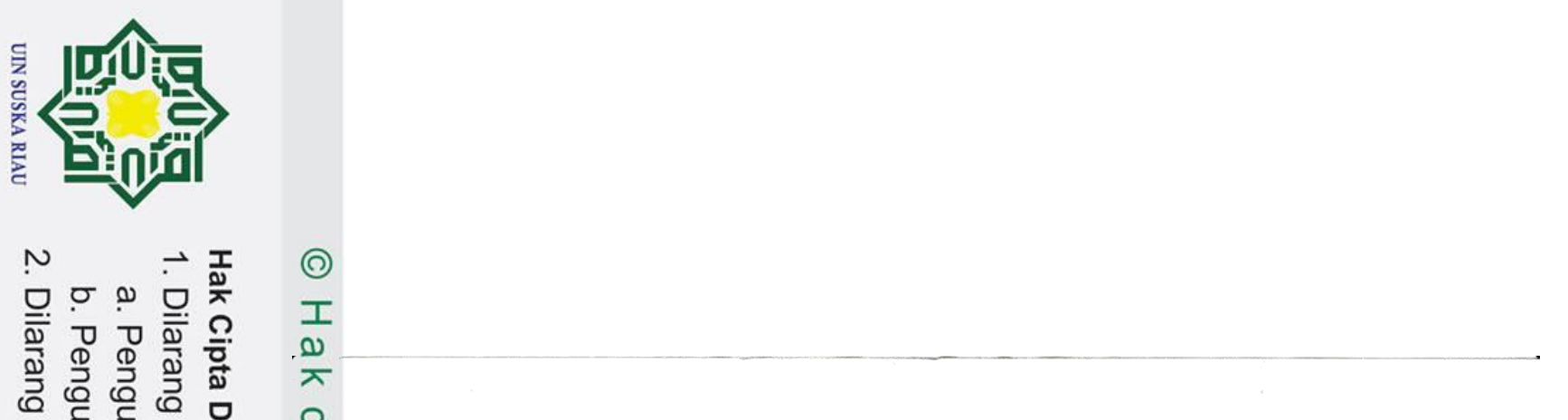

\section{LEMBAR PENGESAHAN SKRIPSI}

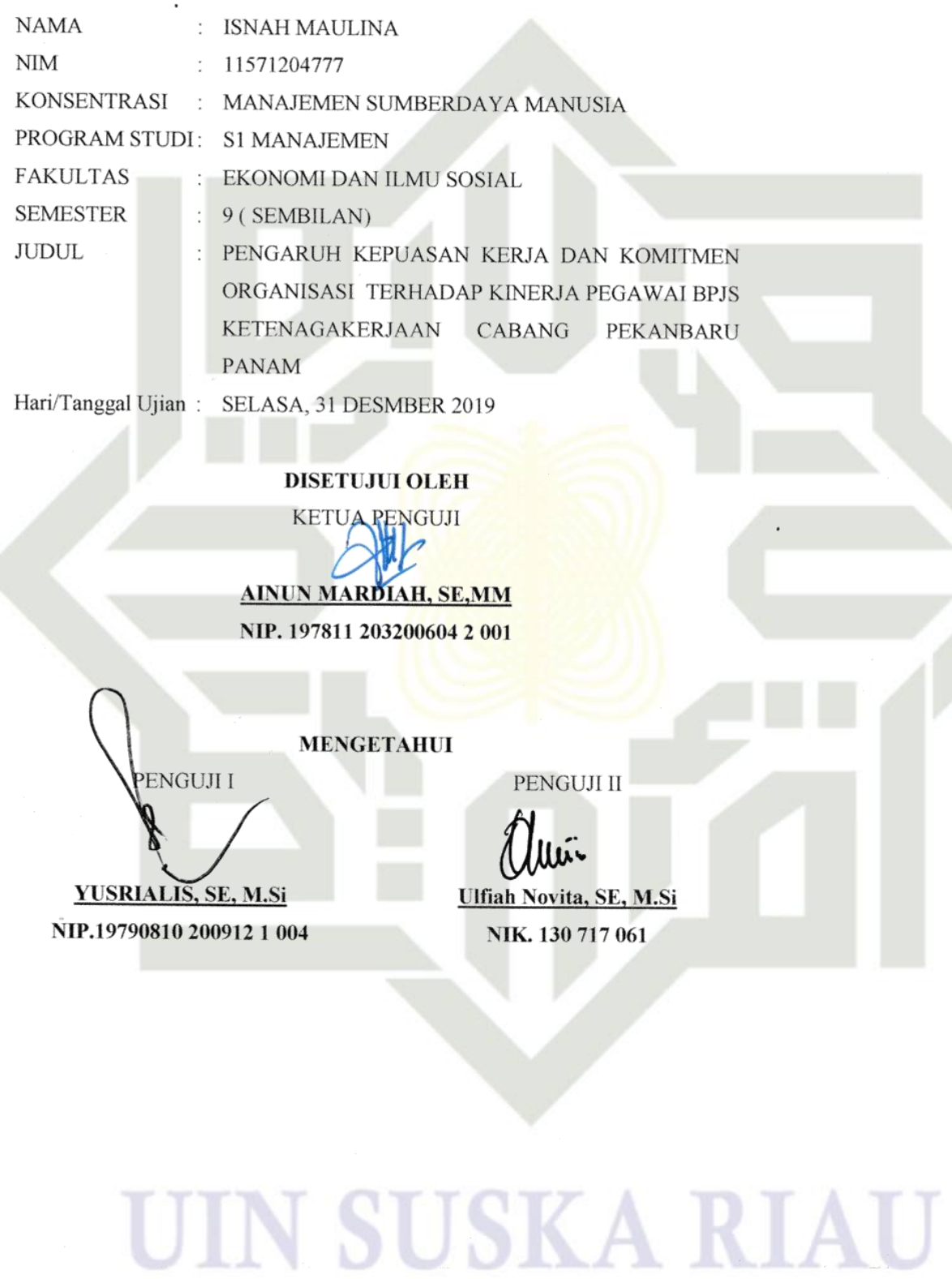




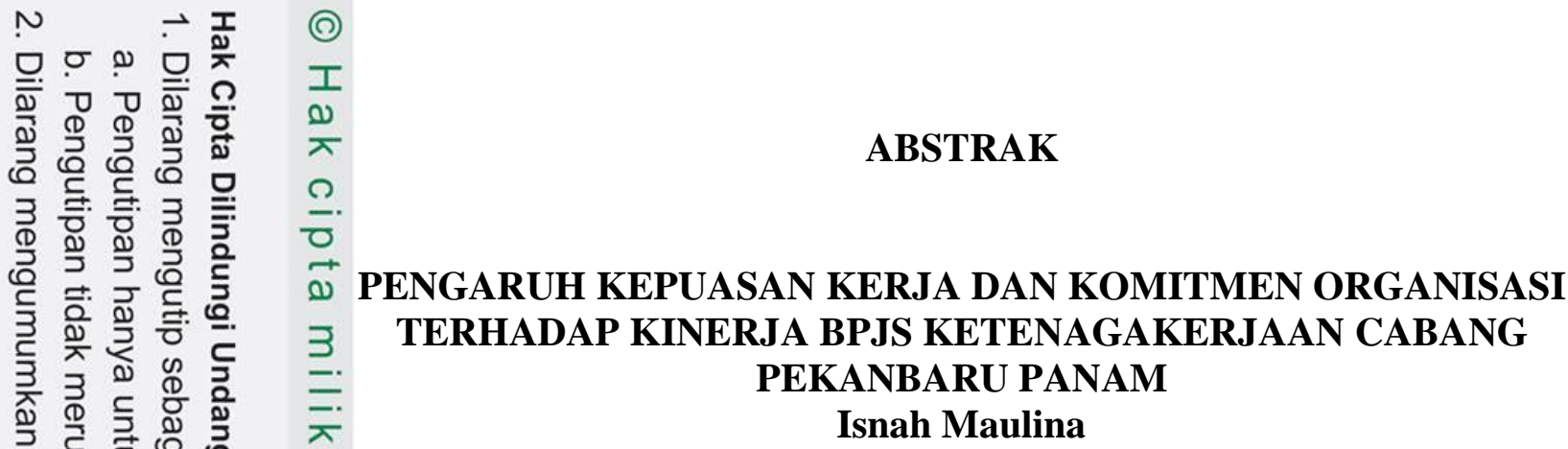

Penelitian ini dilakukan pada BPJS ketenagakerjaan Cabang Pekanbaru Panam. Tujuan penelitian ini adalah untuk mengetahui pengaruh kepuasan kerja dan Somitmen organisasi terhadap kinerja BPJS Ketenagakerjaan Cabang Pekanbaru $\bar{B}$ anam, baik secara parsial maupun simultan. Adapun populasi dalam penelitian i⿱丆贝ুi $i$ adalah seluruh pegawai BPJS Ketenagakerjaan Cabang Pekanbaru Panam sebanyak 25 orang. Metode penentuan sampel dalam penelitian ini menggunakan sampel jenuh atau sensus. Data yang digunakan adalah data primer dan data Sekunder. Metode analisis data yang digunakan adalah metode regresi linear berganda. Hasil penelitian menunjukkan bahwa secara parsial kepuasan kerja berpengaruh terhadap kinerja pegawai BPJS ketenagakerjaan Cabang Pekanbaru Panam. Komitmen organisasi secara parsial berpengaruh terhadap kinerja pegawai BPJS ketenagakerjaan Cabang Pekanbaru Panam. Secara simultan kepuasan kerja dan komitmen organisasi memiliki pengaruh terhadap kinerja pegawai BPJS ketenagakerjaan Cabang Pekanbaru Panam. Besar pengaruh kepuasan kerja dan komitmen organisasi memiliki pengaruh terhadap kinerja pegawai BPJS ketenagakerjaan Cabang Pekanbaru Panam ditunjukkan dengan koefisien determinasi sebesar 0,667. Hal ini menunjukkan bahwa 66,7\% kinerja pegawai di pengaruhi oleh kepuasan kerja dan komitmen organisasi dan sisanya sebesar 0,333 atau 33,3\% dipengaruhi oleh variabel lain yang tidak digunakan dalam penelitian ini. 


\section{KATA PENGANTAR}

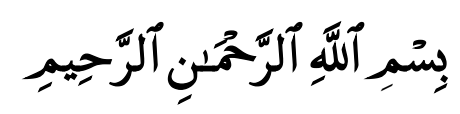

Puji syukur kehadirat Allah SWT yang telah melimpahkan rahmat dan hidayahnya sehingga saya sebagai penulis dapat menyelesikan skripsi yang berjudul "Pengaruh kepuasan kerja dan komitmen organisasi terhadap kinerja () pegawai BPJS ketenagakerjaan cabang pekanbaru panam” yang disusun sebagai त) syarat Akademis dalam penyelesaian Program Studi Manajemen (S1), Fakultas ‥ 鼠onomi dan Ilmu Sosial, Universitas Islam Negeri Sultan Syarif Kasim Riau. Saya sebagai penulis menyadari bahwa skripsi ini tidak mungkin terselesaikan tanpa dukungan, bimbingan, bantuan, serta do'a dari berbagai pihak selama penyusunan skripsi. Pada kesempatan ini saya sebagai penulis dengan segala kerendahan hati mengucapkan terima kasih kepada:

1. Bapak Prof. Dr. H. Akhmad Mujahidin, S.Ag.,M.Ag, sebagai rektor UIN $\omega$ Suska Riau, yang telah memberikan kesempatan penulis untuk menimba ilmu pengetahuan di Universitas tercinta ini.

Bapak Dr. Drs. H. Muh. Said HM, M.Ag, MM selaku dekan Fakultas Ekonomi dan Ilmu Sosial Universitas Islam Negeri Sultan Syarif Kasim Riau. Ibu Ainun Madhiah, SE, MM selaku ketua jurusan Manajemen Fakultas Ekonomi dan Ilmu Sosial Universitas Islam Negeri Sultan Syarif Kasim Riau. Ibu Putriana, SE, MM. selaku pembimbing yang telah bersedia meluangkan $\stackrel{0}{\circ}$

@ waktunya untuk memberikan arahan, bimbingan, perhatian dan saran-saran

kepada penulis sehingga penulis bisa menyelesaikan skripsi ini hingga selesai. 


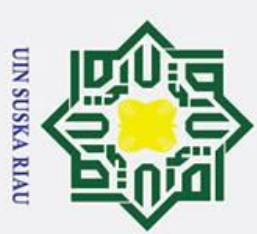

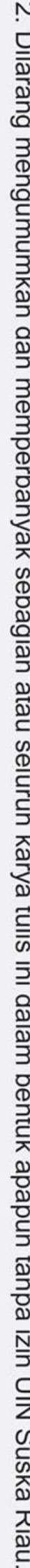

banyak membantu dalam memberikan sumbangan saran dan pemikiran dalam

3 pengembangan ilmu dan pengetahuan saya sebagai mahasiswa Fakultas Ekonomi dan Ilmu Sosial Universitas Islam Negeri Sultan Syarif Kasim Riau. Bapak dan Ibu Dosen Fakultas Ekonomi dan Ilmu Sosial Universitas Islam

Negeri Sultan Syarif Kasim Riau yang telah memberikan ilmu pengetahuannya kepada penulis selama penulis dalam masa perkuliahan.

Seluruh Karyawan Fakultas Ekonomi dan Ilmu Sosial Uiniversitas Islam Negeri Sultan Syarif Kasim Riau yang telah memberikan bantuan selama perkuliahan baik secara langsung maupun tidak langsung.

8. Semua pihak yang tidak dapat penulis sebutkan satu persatu yang telah banyak membantu dalam menyelesaikan skripsi ini.

9. Kepada pimpinan BPJS ketenagakerjaan cabang pekanbaru panam yang telah banyak memberikan bantuan dalam penyusunanskripsi ini terutama bantuan () data primer maupun sekunder.

Penulis 

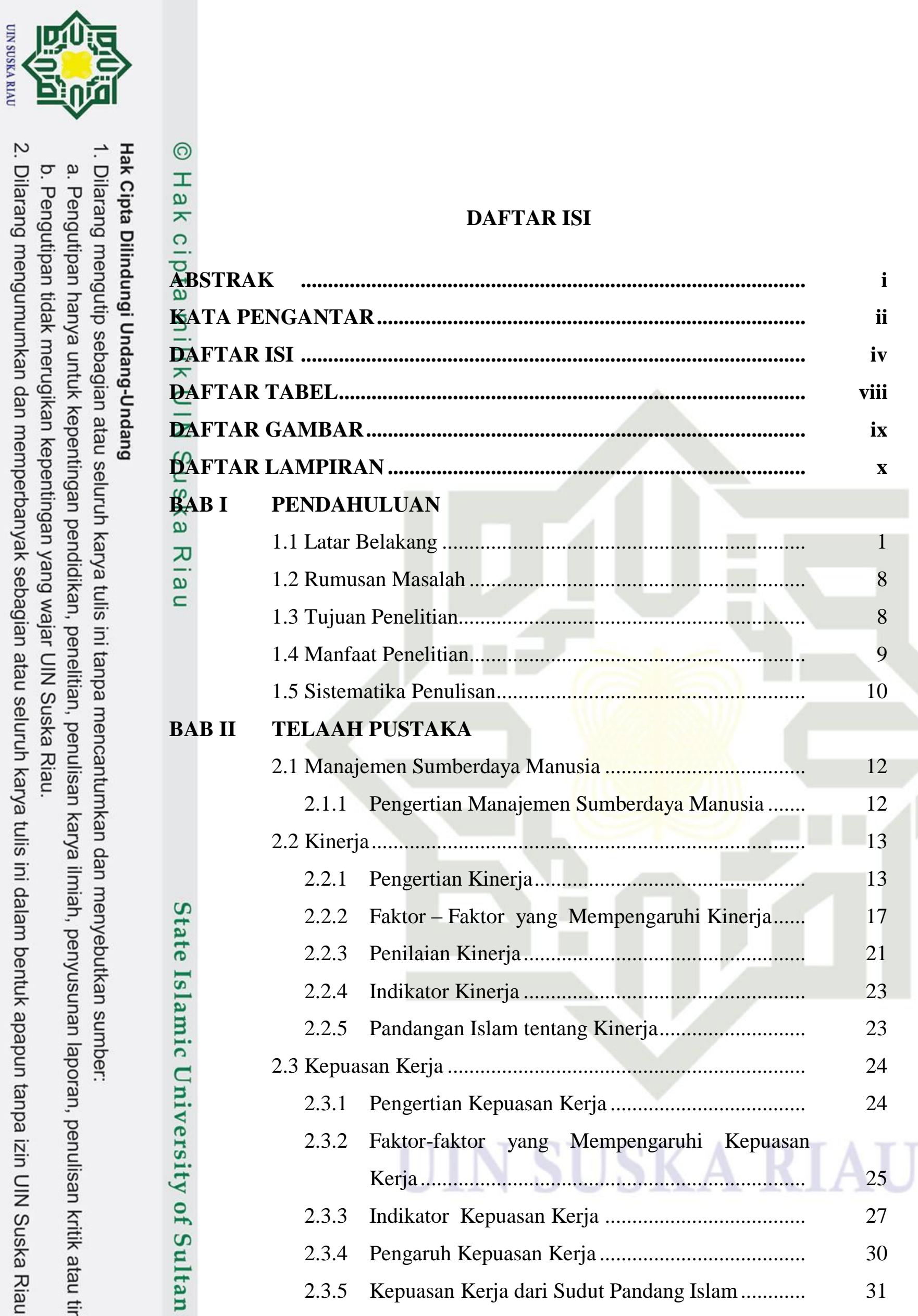


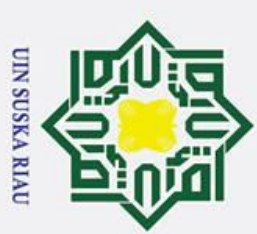

2.4 Komitmen Organisasi

2.4.1 Faktor-faktor yang Mempengaruhi Komitmen

Organisasi

2.4.2 Indikator Komitmen Organisasi

2.4.3 Dampak Komitmen Organisasi

2.4.4 Pedoman untuk Meningkatkan Komitmen Organisasional

2.4.5 Bentuk Komitmen Organisasi

2.4.6 Komitmen Organisasi dari Pandang Sudut Islam 39

2.5 Penelitian Terdahulu 42

2.6 Kerangka Pemikiran 43

2.7 Kerangka Konsep Pemikiran Penelitian..........................

2.8 Hipotesis ................................................................. 45

2.9 Definisi Operasional.................................................. 46

\section{BAB III METODE PENELITIAN}

3.1 Lokasi dan Waktu Penelitian.............................................. 48

3.2 Populasi dan Sample Penelitian .......................................

3.2.1 Populasi ............................................................ 48

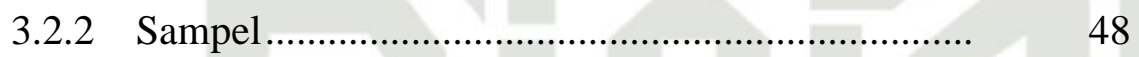

3.3 Jenis dan Sumber Data .....................................................

3.4 Teknik Pengumpulan Data .............................................. 49

3.5 Skala Pengukuran .................................................... $\quad 50$

3.6 Uji Kualitas Data.................................................... $\quad 50$

3.6.1 Uji Validitas ................................................... 51

3.6.2 Uji Reliabilitas................................................. 51

3.7 Teknik Analisis Data........................................... $\quad 51$

3.7.1 Metode analisis Deskriptif ................................ 51

3.7.2 Metode Analisis Kuantitatif ................................ 52

3.8 Uji Asumsi Klasik ................................................... 52

3.8.1 Uji Normalitas ............................................... 52

3.8.2 Uji Multikolinieritas...................................... 53 

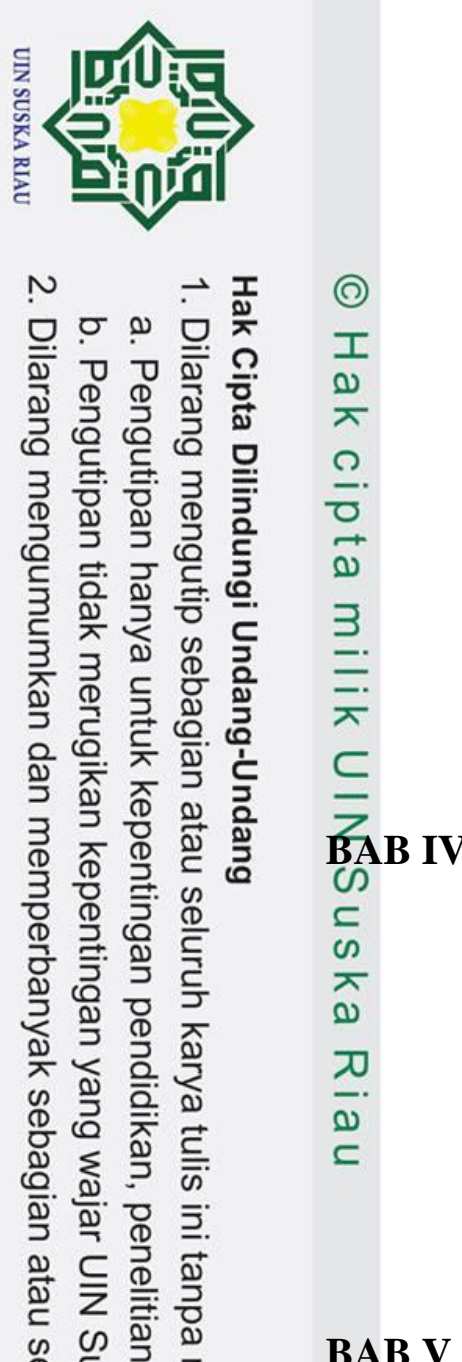

3.8.3 Uji Heteroskedastisitas

3.9 Analisis Regresi Linier Berganda ............................... $\quad 54$

3.10 Uji Hipotesis .......................................................... 55

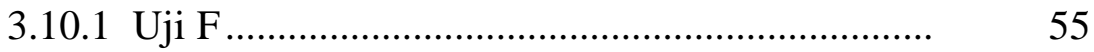

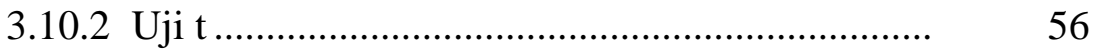

3.10.3 Kofisien Determinasi ...................................... $\quad 56$

GAMBARAN UMUM PERUSAHAAN

4.1 Sejarah Perusahaan.

4.2 Visi, Misi BPJS Ketenaga Kerjaan Cabang Pekanbaru

Panam 62

4.3 Struktur Organisasi. 62

4.4 Aktifitas Perusahaan. 65

4.5 Tugas dan Fungsi

BAB V HASIL PENELITIAN DAN PEMBAHASAN

5.1 Karakteristik Responden .............................................. $\quad 78$

5.1.1 Responden Berdasarkan Jenis Kelamin ................ 78

5.1.2 Responden Berdasarkan Masa Kerja..................... 79

5.1.3 Responden Berdasarkan Usia.............................. $\quad 79$

5.1.4 Responden Berdasarkan Pendidikan Terakhir ...... 80

5.2 Deskriptif Variabel ........................................................... 81

5.2.1 Analisis Deskriptif Variabel Kinerja..................... 81

5.2.2 Analisis Deskriptif Variabel Kepuaan Kerja......... 83

5.2.3 Analisis Deskriptif Variabel Komitmen Organisasi ....................................................... 86

5.3 Uji Kualitas Instrumen Penelitian ..................................... $\quad 88$

5.3.1 Uji Validitas ........................................... $\quad 88$

5.3.2 Uji Reliabilitas............................................. $\quad 90$

5.4 Uji Asumsi Klasik .................................................... $\quad 90$

5.4.1 Uji Normalitas Data ............................................ 91

5.4.2 Uji Multikolinieritas.......................................... 92

5.4.3 Uji Heteroskedastisitas ......................................... 93 
5.5 Analisis Data Penelitian .................................................... 94

5.5.1 Regresi Linier Berganda ....................................... 94

5.5.2 Uji hipotesis......................................................... 96

5.5.2.1 Uji Secara Parsial (Uji T) .......................... 96

5.5.2.2 Uji Secara Simultan (Uji F) ........................ 97

5.5.2.3 Koefisien Determinasi $\left(\mathrm{R}^{2}\right)$...................... $\quad 98$

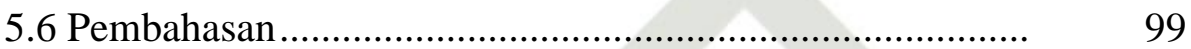

5.6.1 Pengaruh Kepuasan Kerja Terhadap Kinerja

Pegawai BPJS Ketenagakerjaan Cabang

Pekanbaru Panam ................................................... 100

5.6.2 Pengaruh Komitmen Organisasi Terhadap Kinerja

Pegawai BPJS Ketenagakerjaan Cabang

Pekanbaru Panam ................................................... 102

5.6.3 Pengaruh Kepuasan Kerja dan Komitmen

Organisasi Terhadap Kinerja Pegawai BPJS

Ketenagakerjaan Cabang Pekanbaru Panam .......... 104

5.6.4 Variabel yang paling berpengaruh antara

Kepuasan Kerja daan Komitmen Organisasi

Terhadap Kinerja Pegawai BPJS Ketenagakerjaan

Cabang Pekanbaru Panam

BABB VI PENUTUP

6.1 Kesimpulan

6.2 Saran

108

\section{DAFTAR PUSTAKA}

BIOGRAFI PENULIS

के 

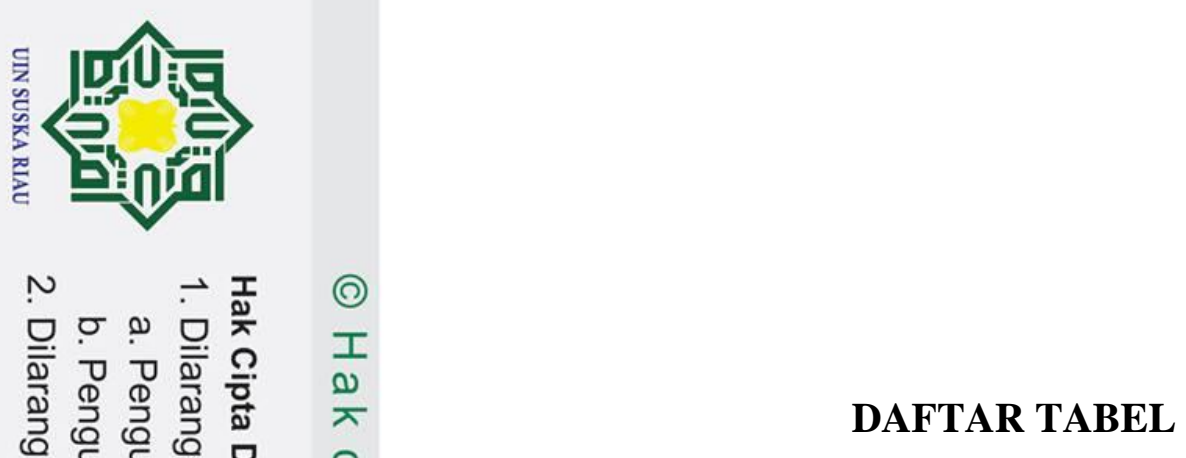

Halaman

a)

Eabel 1.1 Data Target dan Realisasi Kinerja pelayanan BPJS

ב. Ketengakerjaan Cabang Pekanbaru Panam dari Tahun 2015 2018 .

Fa bel 1.2 Data Absensi karyawan BPJS ketengakerjaan Cabang

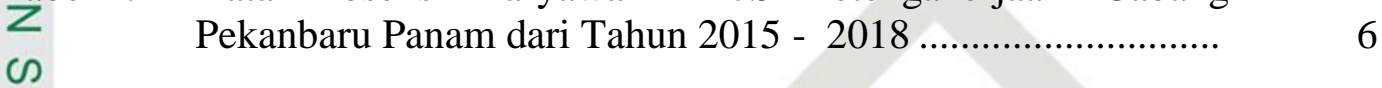

$\omega$

Täbel 2.1 Penelitian Terdahulu ........................................................... 42

Tabel 2.2 Definisi dan Konsep Operasional Variabel............................... 47

70

Täbel 5.1 Jumlah Responden Berdasarkan Jenis Kelamin...................... 78

c

Tabel 5.2 Responden Berdasarkan Masa Kerja................................... $\quad 79$

Tabel 5.3 Jumlah Responden Berdasarkan Usia ................................. 80

Tabel 5.4 Jumlah Responden Berdasarkan Pendidikan Terakhir............ $\quad 80$

Tabel 5.5 Rekapitulasi Tanggapan Responden Variabel Kinerja............ 82

Tabel 5.6 Rekapitulasi Tanggapan Responden Variabel Kepuasan Kerja $\quad 84$

Tabel 5.7 : Rekapitulasi Tanggapan Responden Variabel Komitmen

Organisasi .................................................................. 86

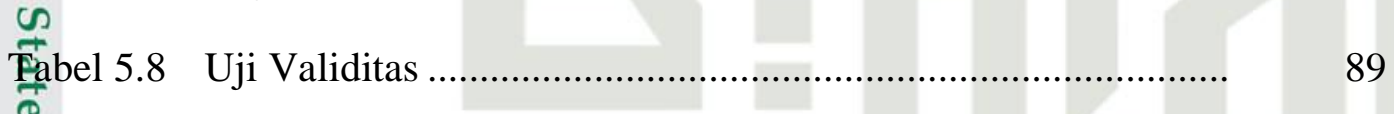

Täbel 5.9 Uji Reliabilitas................................................................ 90

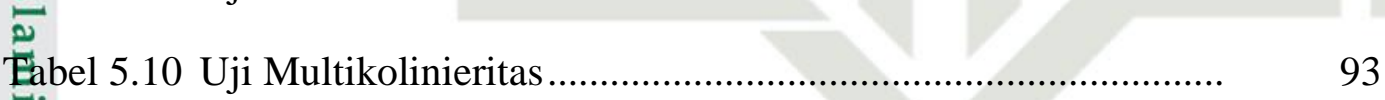

Täbel 5.11 Analisis Regresi Berganda ..................................................... 95

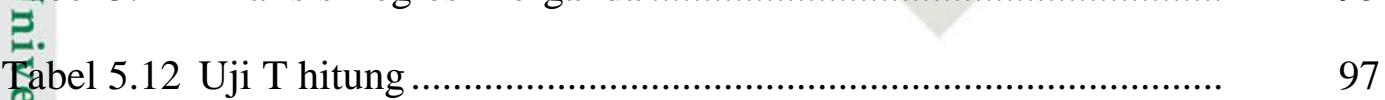

Tabel 5.12 Uji T hitung .................................................................

Fabel 5.13 Uji F hitung .................................................................... 98

Pąbel 5.14 Koefisien Determinasi........................................................ 99 

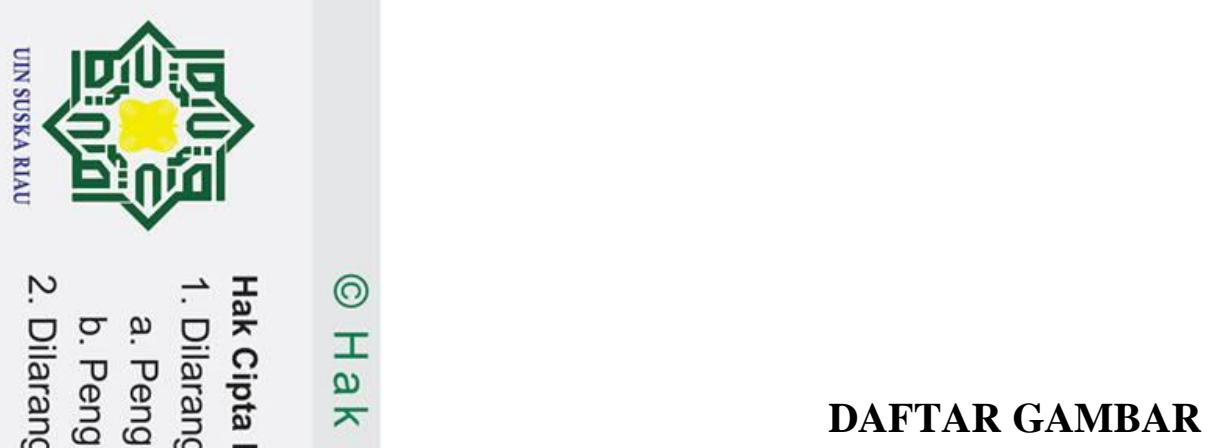

Halaman

$\vec{a}$

Gambar 2.1 Model Kerangka Pemikiran Tentang Pengaruh Kepuasan

三. Kerja (X1) dan Komitmen organisasi (X2) Terhadap

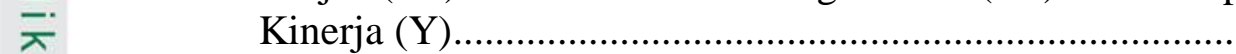

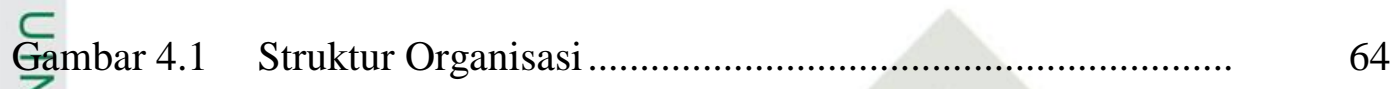

Gambar 5.1 Uji Normalitas Histogram .............................................. 91

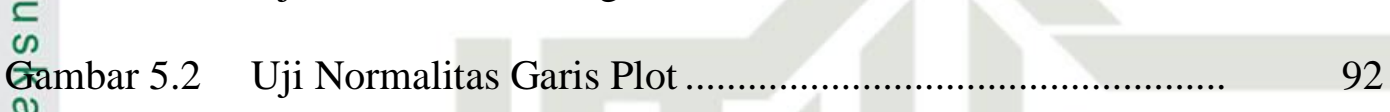

Ğ Gambar 5.3 Uji Heteroskedastisitas ................................................... 94

$\stackrel{0}{(2)}$

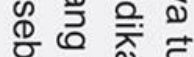

纯

产 욕

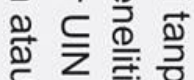

Q

D)

들 क्ष

今 끌

젱 ज

$\subset$ 

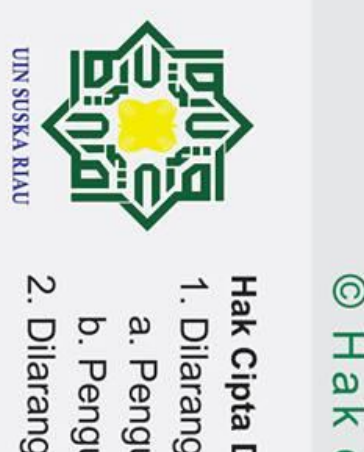

\section{DAFTAR LAMPIRAN}

Halaman

a)

Eampiran 1. Uji Coba Angket

L्ămpiran 2. Data Uji Coba Validitas

Łampiran 3. Uji Reabilitas

Z

Lampiran 4. Angket

Campiran 5. Data Variabel-Variabel Penelitian (1)

நampiran 6. Data SPSS

$\stackrel{-}{\complement}$

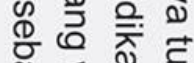

这 结

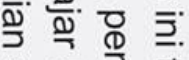

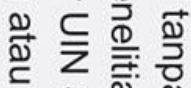

की

足

喜 끌

त

क

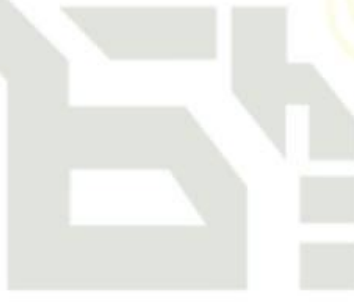



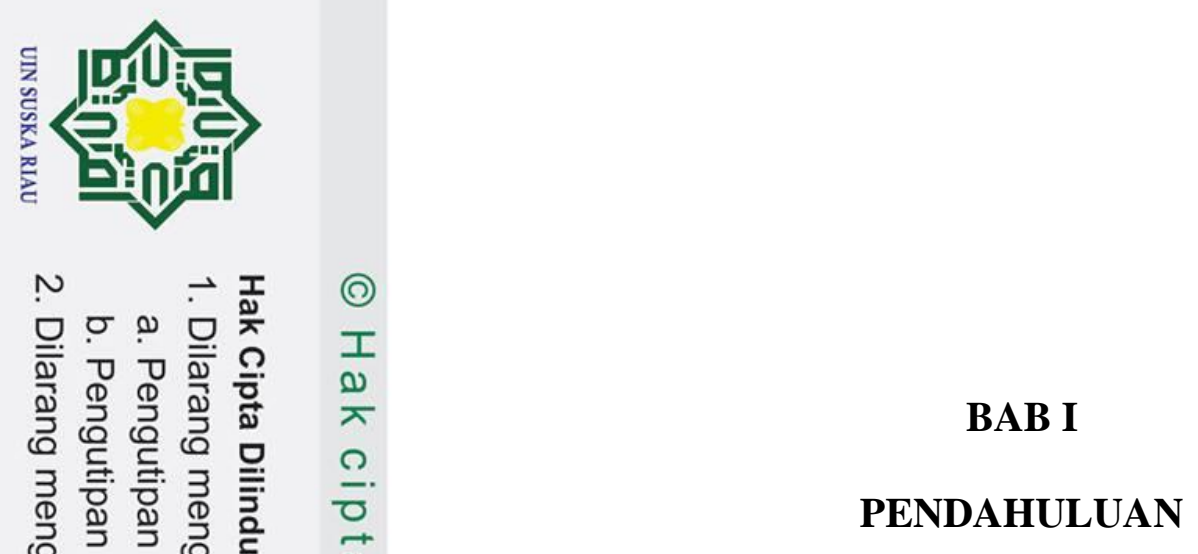

\subsection{Latar Belakang}

$\subset$ Globalisasi telah menyebabkan Indonesia dibanjiri perusahaan-perusahaan asuransi kelas dunia yang memberikan layanan prima bagi para pekerja di क Indonesia. Yang menjadi tantangan utama adalah bagaimana dengan kesiapan $\pi$

perusahaan-perusahaan asuransi nasional ataupun badan pemerintah yang diberi tângngung jawab memberikan layanan bagi seluruh lapisan pekerja di Indonesia.

Bahkan bagi para pekerja yang tidak mungkin ditanggung oleh perusahaan asuransi yang hanya berorientasi keuntungan belaka.

Sumber daya manusia merupakan kekuatan daya pikir dan berkarya manusia yang masi tersimpan dalam diri, yang perlu digali, di bina, dikembangkan untuk dimanfaatkan sebaik - baiknya bagi kesejahteraan kehidupan manusia. Sumber daya manusia merupakan kemampuan potensial yang dimiliki manusia yang a

têّrdiri dari kemampuan berpikir, berkomunikasi, bertindak, dan bermoral untuk to

melaksanakan kegiatan.

Manajemen sumber daya manusia sala satu bagian dari manajemen yang menfokuskan pada unsur sumber daya manusia. Manajemen sumberdaya manusia 送

memiliki tugas mengelola sumberdaya manusia secara efektif dan efisien agar क.

minendapatkan tenaga kerja yang puas atas kerjanya melalui kegiatan perencanan, $\stackrel{\circ}{\rightarrow}$

pênggerakan dan pengendalian semua nilai yang menjadi kekuatan manusia dalam (1)

ติencapai tujuan. Peran manusia sangat penting dalam organisasi, meskipun berbagai faktor itu sudah tersedia, tanpa peran manusia organisasi tidak akan

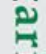




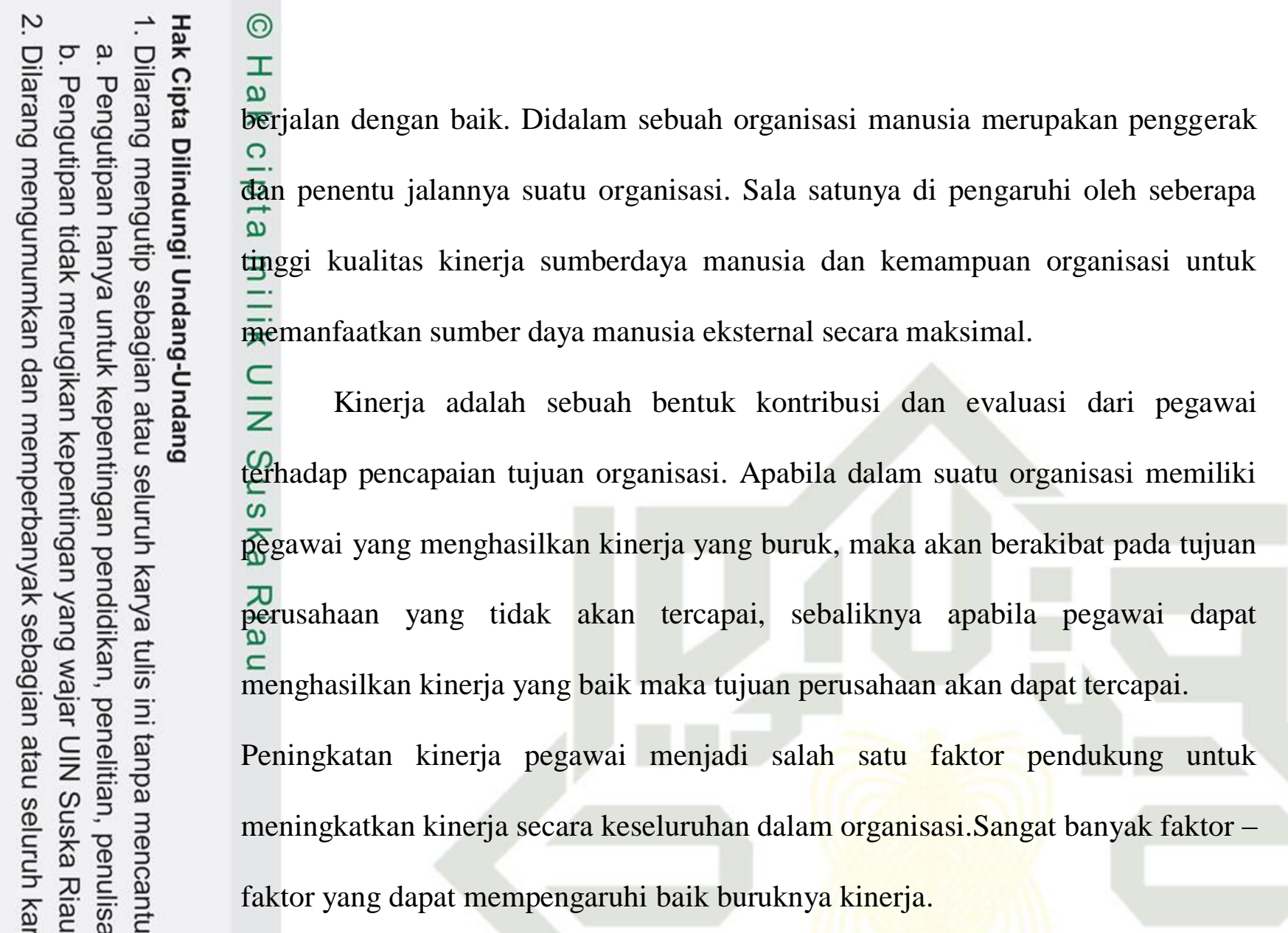

Kasmir (2016:189) mengatakan bahwa kinerja pegawai dipengaruhi oleh faktor - faktor kemampuan dan keahlian, pengetahuan, rancangan kerja,keperibadian,motivasi kerja, kepemimpinan,gaya kepemimpinan, budaya $\stackrel{2}{\circ}$ organisasi, kepuasan kerja, komitmen organisasi,lingkungan kerja,loyalitas dan

ब⿳⺈⿴囗十大

Dengan demikian kepuasan kerja dan komitmen organisasi termasuk dari $\exists$ saliah satu faktor yang mempengaruhi kinerja seorang pegawai kepuasan kerja dan ? komitmen organisasi sangat penting bagi sebuah perusahaan. untuk mengertahui

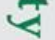

sejauh mana kepuasa kerja dan komitmen ornganisasi seorang pegawai dalam N

bekkerja yang makasimal dan sejauh mana pengaruh terhadap kinerja perusahaan (2) ity sendiri. Hal ini diperkuat oleh penelitian terdahulu yang dilakukan Mardiani 


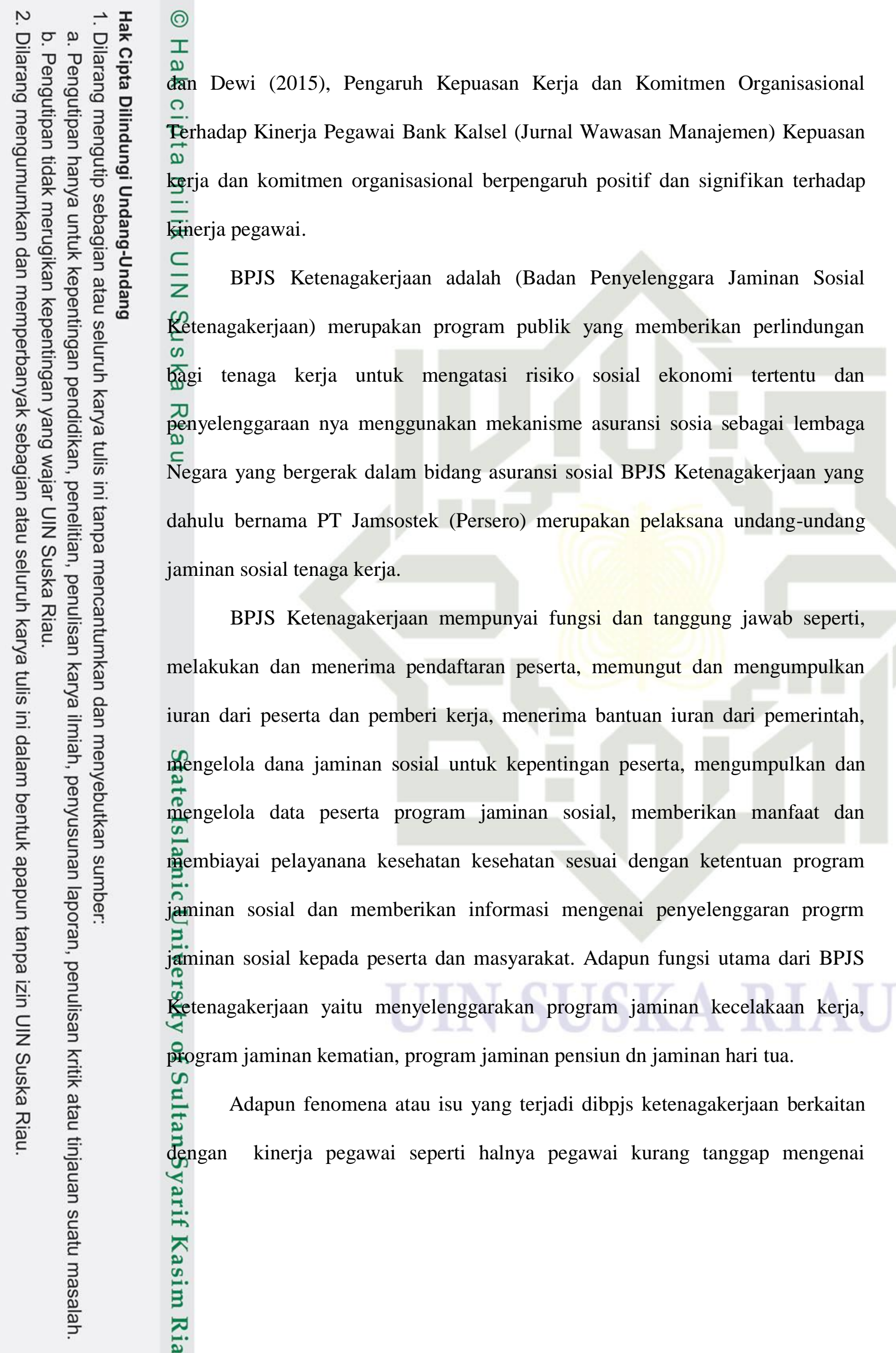


penyampaian informasi pencairan klim dana kepada nasabah dan pelayanan yang ‥

địberikan kepada nasabah kurang baik ini disebabkan karana adanya ketidak $\vec{a}$

lengkapan tugas dalam organisasi, atau pun kemampuan pegawai dalam

berkerja,dan kesediaan untuk menerima tanggung jawab dalam berkerja.

$\bar{\complement}$ Tingkat kepuasan kerja merupakan salah satu faktor yang memengaruhi prestasi kerja, yang pada akhirnya memiliki pengaruh os

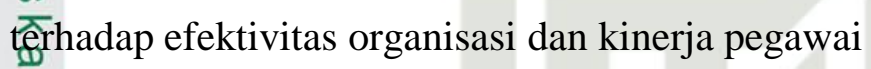

글.

Kepuasan kerja pegawai pada Badan Penyelenggaraan Jaminan Sosial

$\stackrel{ᄃ}{(\mathrm{BPJS})}$ Cabang Pekanbaru Panam adanya tinggkat absensi dan realisai kinerja pelayanan yang menurun disebabkan karena adanya ketidak puasan pegawai dalam bekerja sehingga kinerja seorang pegawai tidak mencapai target.hal ini berpengaruh terhadap kinerja pegawai BPJS ketenagakerjaan cabang pekanbaru panam. Ini terlihat jelas dari data perusahaan mengenai keadaan pegawai dari tahun $2015-2018$ adalah sebagai berikut :

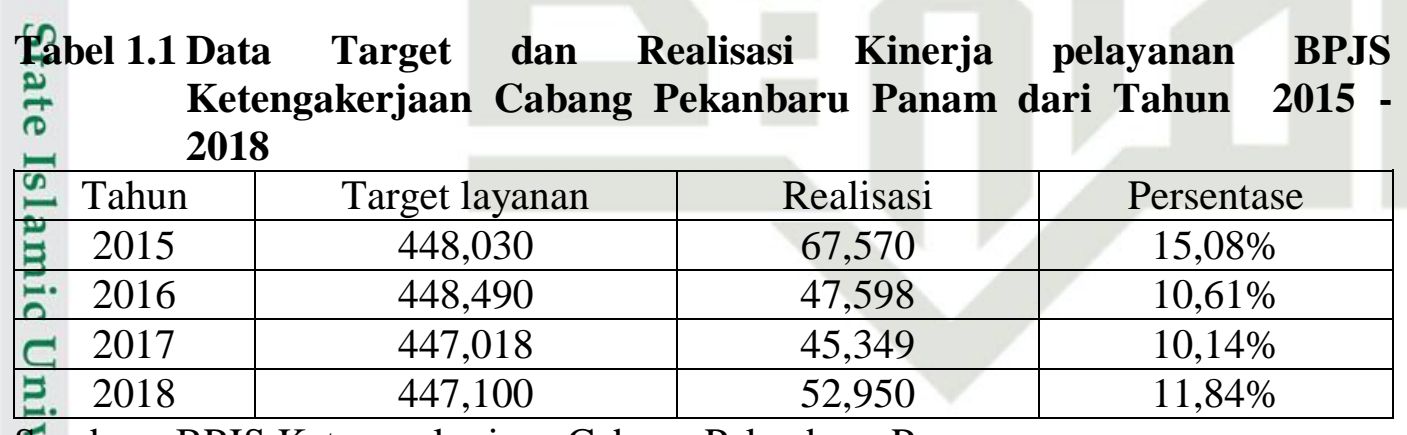

S్gumber : BPJS Ketenagakerjaan Cabang Pekanbaru Panam

Berdasarkan data tabel 1.3 Target layanan realisasi yang terjadi dari tahun

2015 sebesar $15,08 \%$ dan pada tahun 2018 sebesar 11,84\% Target dari tahun क

2015-2018 mengalami penurunan hal ini terjadi karna pada kenyataannya kinerja 킹

yang tinggi tidak semua dimiliki oleh setiap karyawan, ada juga sebagian pegawai

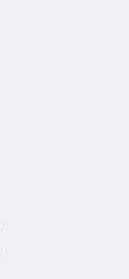




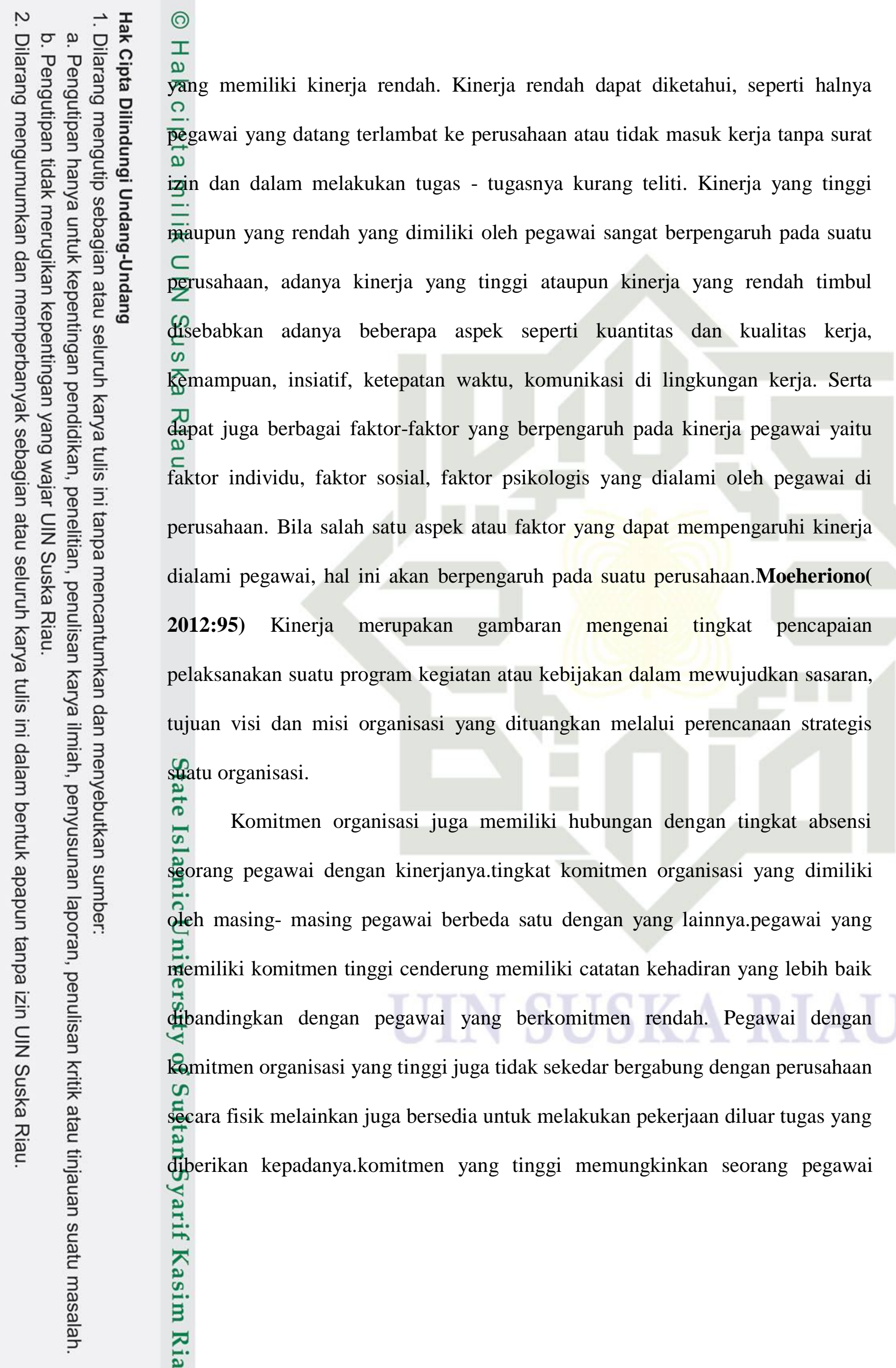




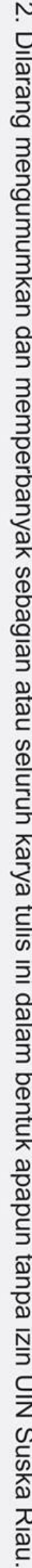

工

a)

üntuk menekan timbulnya stres kerja serta berjuang keras menghadapi ?.

Æৈntangan dan tekanan yang ada. Pegawai yang memiliki komitmen tinggi a)

çnderung memiliki catatan kehadiran yang lebih baik dan masa kerja yang lebih $\overline{\bar{F}}$ 穴na dibandingkan dengan pegawai yang berkomitmen rendah.

Tabel 1.2 Data Absensi karyawan BPJS ketengakerjaan Cabang Pekanbaru Panam dari Tahun 2015 - 2018

\begin{tabular}{|c|c|c|c|c|c|c|}
\hline$\frac{\text { Periode }}{\infty}$ & $\begin{array}{c}\text { Sakit } \\
\text { (orang) }\end{array}$ & $\begin{array}{c}\text { Izin } \\
\text { (orang) }\end{array}$ & $\begin{array}{c}\text { Alfa } \\
\text { (orang) }\end{array}$ & $\begin{array}{l}\text { Jumlah } \\
\text { (orang) }\end{array}$ & $\begin{array}{c}\text { Jumlah } \\
\text { keterlambatan }\end{array}$ & $\%$ \\
\hline त्र 2015 & 37 & 21 & 28 & 86 & 11 & 97 \\
\hline$\chi^{2016}$ & 35 & 25 & 20 & 85 & 7 & 92 \\
\hline-2017 & 30 & 20 & 26 & 76 & 8 & 86 \\
\hline ¿ 2018 & 40 & 25 & 20 & 88 & 10 & 98 \\
\hline
\end{tabular}

Sumber : BPJS Ketenagakerjaan Cabang Pekanbaru Panam

Indikasi yang diperoleh dari gambar 1.2 menunjukkan kehadiran pegawai dari tahun 2015 - 2018 Berdasarkan tabel diatas dapat diketahui tingkat kehadiran pegawai fluktuatif dan mengalami penurunan. kehadiran yang paling rendah terjadi pada 2017 dan pada tahun 2018 tingkat kehadiran sebesar 98\% ini terjadi karna adanya indikasi rendahnya kinerja pegawai yang ditunjukkan dengan meningkatnya angka absensi dan adanya rasa kurang puas terhadap salah satu อ

unsur kepuasan kerja. Jika komitmen organisasi dan kepuasan kerja pegawai क

meningkat, maka kinerja pegawai akan meningkat. Selain itu keduanya memiliki :

keterkaitan dalam menentukan kinerja . pegawai lebih termotivasi untuk bekerja 范.

lębih keras apabila merasakan kepuasan kerja. dan sebaliknya jika pegawai merasa के

kirang puas dengan pekerjaannya maka kinerja pegawai akan mengalami $\circ$

penurunan,seperti meningkatnya angka absensi. Bagaimana pekerjaan pegawai क akan meningkat jika tingkat kehadirannya kurang baik dalam perusahaan?

: 


\section{.}

Selain kepuasan kerja, kesuksesan perusahaan juga dapat dilihat dari Fomitmen pegawai terhadap organisasi. Newstrom dan Davis (Kaswan, 2012: ()

293) menjelaskan bahwa "komitmen organisasi sering kali mencerminkan

Kepercayaan pegawai terhadap misi dan tujuan organisasi”. Komitmen dapat

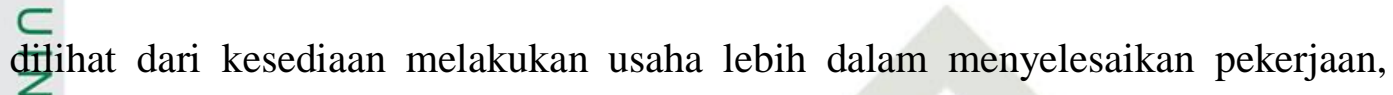
serta keinginan kuat untuk terus bekerja disana.

cs

त) Kinerja yang baik dapat dilihat dari tingkat absensi, serta hasil kerja pegawai. Permasalahan perusahaan ini terkait dengan adanya indikasi rendahnya a)

kinerja pegawai yang ditunjukkan oleh meningkatnya angka absensi serta.kinerja BPJS ketenagakerjaan cabang pekanbaru panam kinerja pegawai dalam melaksanakan tugasnya kurang memuaskan/tidak sesuai harapan karena adanya beberapa hal yang belum dapat tercapai diantaranya kelengkapan tugas dalam organisasi, kemampuan pegawai dalam bekerja, kesediaan untuk menerima tanggung jawab sangat minim informasi terkait proses pengurusan klaim. pelayanan pencairan jaminan hari tua (JHT) bagi karyawan yang berhenti bekerja. $\stackrel{2}{\circ}$

pelayanan yang diberikan tidak memuaskan peserta asuransi sosial karna labatnya क

dึ.

Selain itu masih terdapat perilaku yang tidak baik yang dilakukan pegawai $\exists$ diantaranya yaitu tidak semua pegawai bersedia membantu rekan kerja saat $\stackrel{0}{0}$ mendapat beban kerja lebih, rekan kerja tidak membantu pekerjaan saat pegawai 4 tidak masuk kerja kurangnya partisipasi pegawai dalam kegiatan diluar lapangan, o tidlak bersedia menggantikan rekan kerja saat jam istirahat. Hal tersebut D 


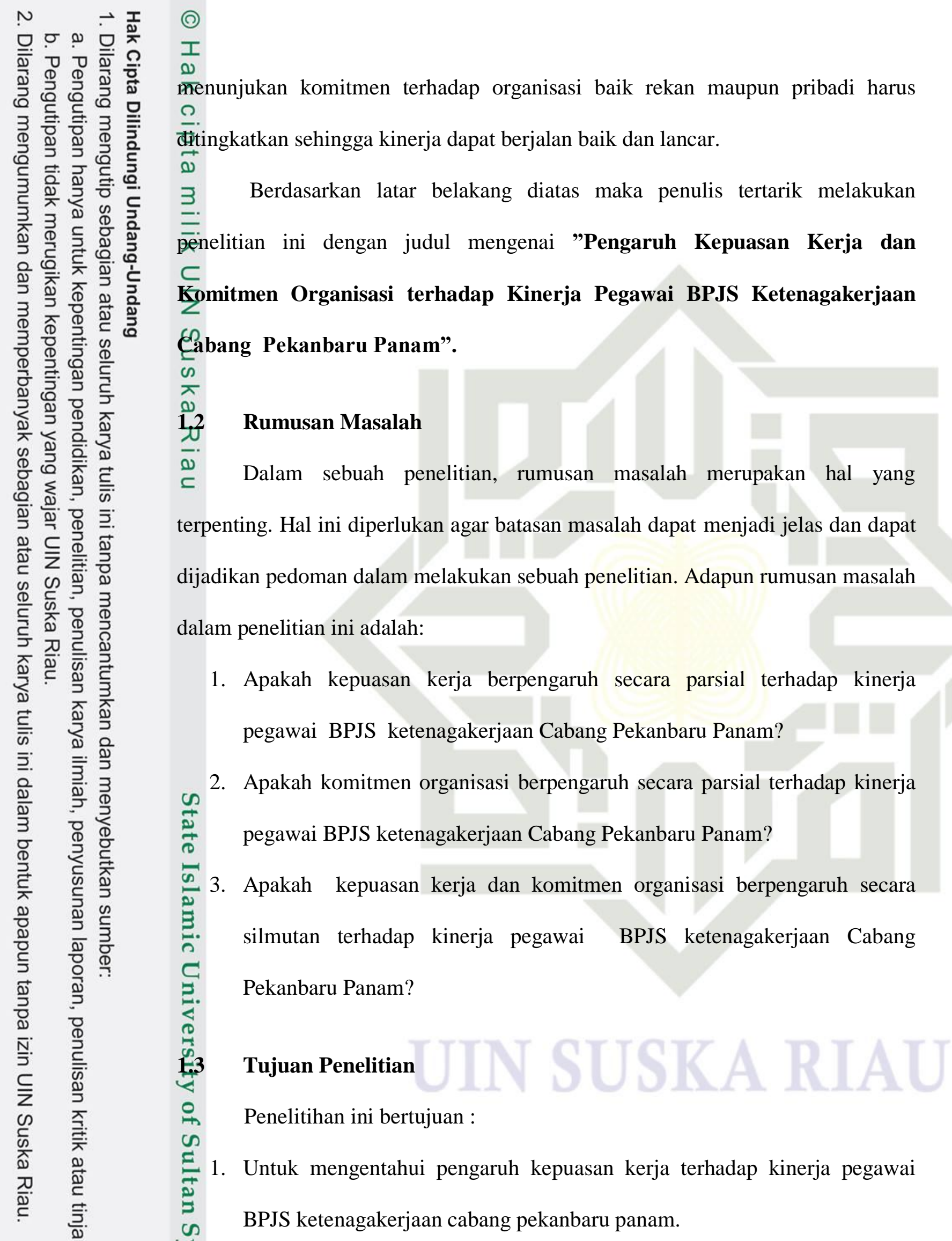




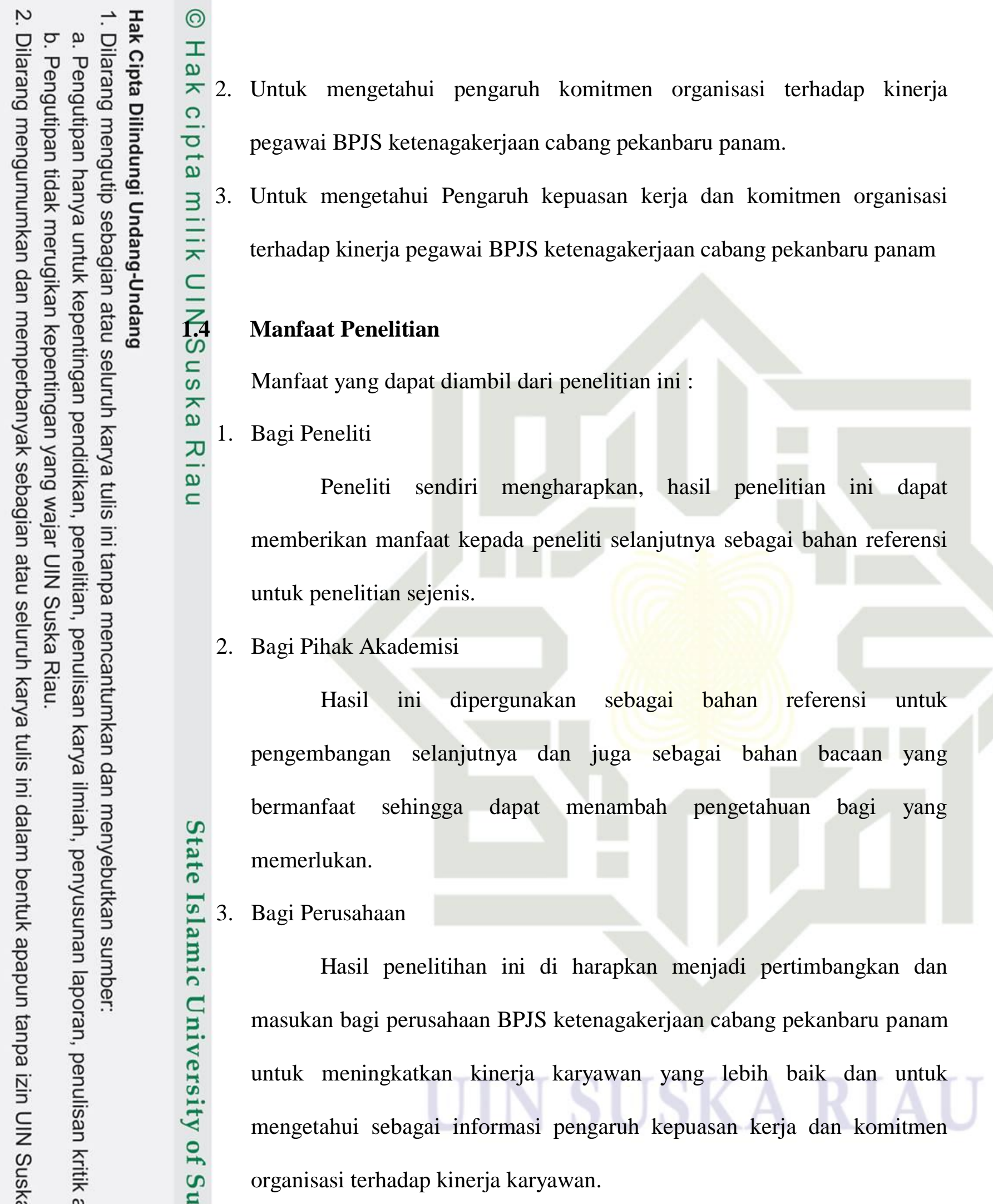


(2)

工

1.5

‥

$\overline{0}$

menyusunnya dalam enam bab, dan setiap babnya akan terdiri dari beberapa sub bäb, kemudian antara bab yang satu dengan yang lainnya akan saling berhubungan dan merupakan satu kesatuan yang tidak dapat dipisahkan.

\section{BAB I : PENDAHULUAN}

ᄃ

is

त)

$\not 0$

ब.

\section{BAB II : TELAH PUSTAKA}

Yakni menguraikan tentang teori yang terkait dengan objek permasalahan antara lain, pengaruh beban kerja dan lingkungan kerja terhadap kinerja.

\section{BAB III : METODE PENELITIAN}

Bab ini memuat tentang lokasi penelitian, populasi dan sampel penelitian, defenisi oprasional variabel, jenis dan sumber data, teknik pengumpulan data serta analisis data.

\section{BAB IV : GAMBARAN UMUM PERUSAHAAN}

Pada bab ini akan diuraikan sejarah singkat lokasi penelitian, sarana dan prasarana

\section{HASIL PENELITIAN DAN PEMBAHASAN}

Yakni merupakan bab pembahasan di mana penulis akan mengemukakan tentang beban kerja dan lingkungan kerja terhadap kinerja karyawan 


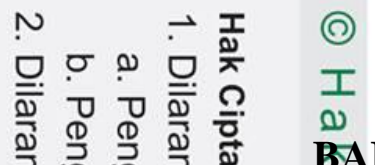

\section{BAB VI : KESIMPULAN DAN SARAN}

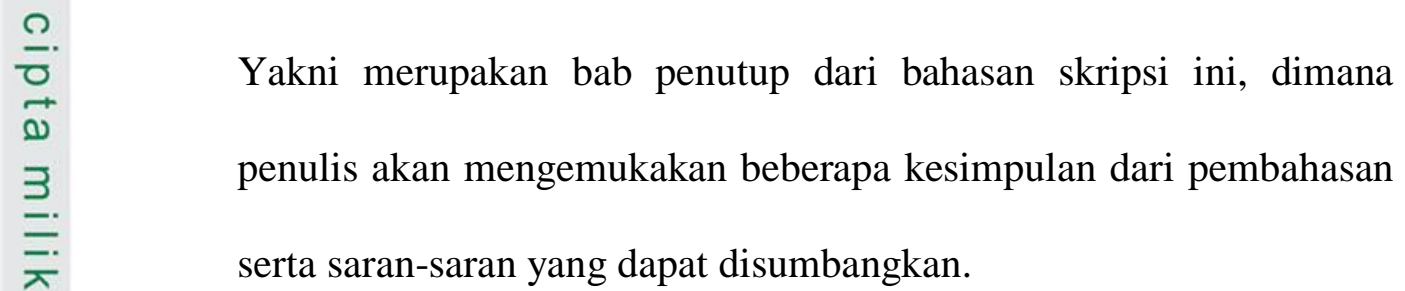



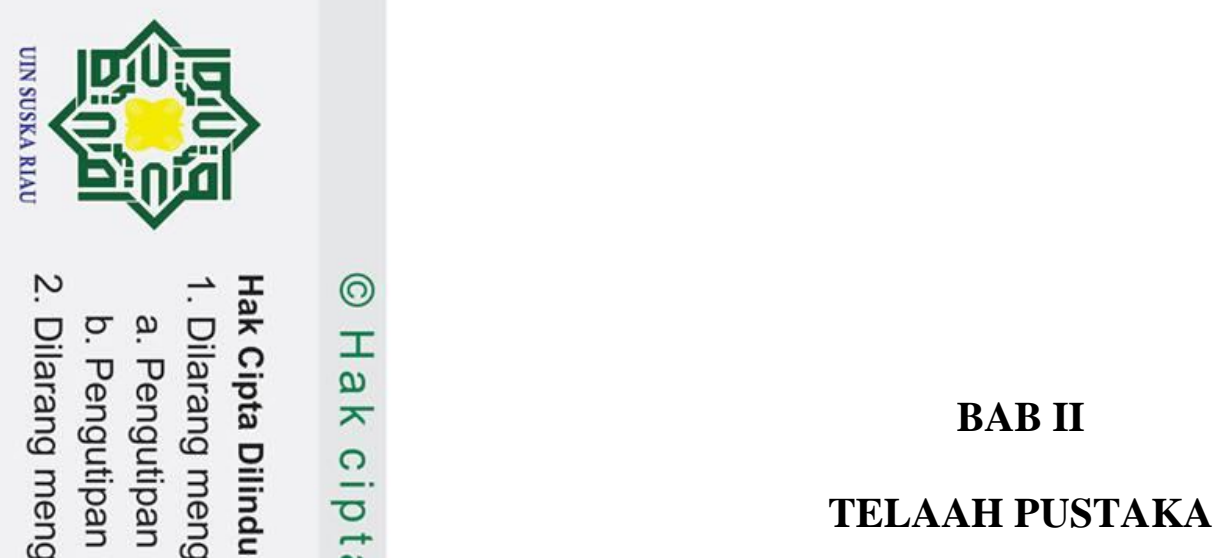

\section{$\underset{3}{3.1}$ Manajemen Sumberdaya Manusia}

\subsubsection{Pengertian Manajemen Sumberdaya Manusia}

Sumber daya manusia merupakan salah satu faktor yang sangat penting dalam suatu perusahaan dibandingkan faktor lainnya seperti modal. Oleh karena $\pi$

ity sumber daya manusia harus dikelola dengan baik untuk meningkatkan ęfektivitas dan efisiensi perusahaan. Manajemen sumber daya manusia (MSDM) sering juga disebut manajemen personalia. Menurut Hasibuan ( 2013 : 10 ) manajemen sumberdaya manusia adalah ilmu dan seni mengatur hubungan dan peranan tenaga kerja agar efektif dan efisien membantu terwujudnya tujuan perusahaan karyawan dan masyarakat. Bohlander (2010 : 4) menyatakan bahwa manajemen sumber daya manusia adalah ilmu yang mempelajari bagaimana memberdayakan pegawai dalam perusahaan, membuat pekerjaan, kelompok kerja,

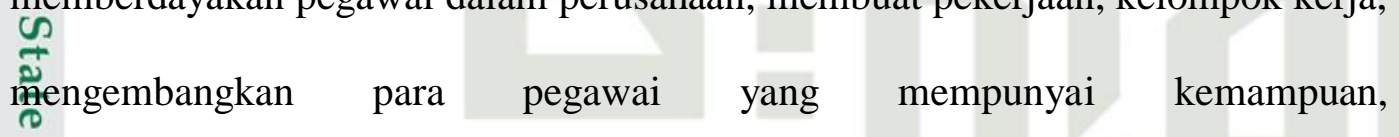
mengidentifikasikan suatu pendekatan untuk dapat mengembangkan kinerja $\stackrel{2}{3}$ pegawai dan memberikan imbalan kepada mereka atas usahanya dalam bekerja.

C. Menurut Kasmir (2016: 6) manajemen sumberdaya manusia adalah proses pengelolahan manusia, melelui perencanaan, pelatihan, pengembangan,

pèmberian kompensasi, karier, keselamatan dan kesehatan serta manjega 옥

Kabungan industrial samapai pemutusan hubungan kerja guna mencapai tujuan $\stackrel{2}{=}$ perusahaan dan peningkatan kesejahteraan stakeholder. 
Rachmawati (2008: 3) mengemukakan Manajemen sumberdaya manusia ‥

aelalah merupakan suatu proses perencanaan, pengorganisasian, pengarahan dan (3)

pengawasan kegiatan - kegiatan pengadaan, pengembangan, pemberian

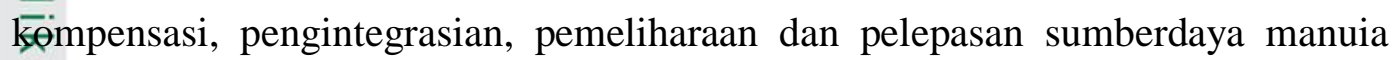

agar tercapi berbagai individu organisasi dan masyarakat.

$\circlearrowleft$ Beberapa pendapat diatas dapat disimpulkan manajemen sumberdaya

œ

דु̆anusia adalah ilmu dan seni mengatur sumberdaya manusia untuk dapat menunjang aktivitas organisasi secara efektif dan efisien dalam mencapai tujuan อง

organiasasi sesuai dengan fungsi - fungsinya.

\subsection{Kinerja}

\subsubsection{Pengertian Kinerja}

Suatu organisasi perusahaan didirikan karena mempunyai tujuan tertentu yang ingin dan harus dicapai. Dalam mencapai tujuannya setiap organisasi di pengaruhi perilaku organisasi. Salah satu kegiatan yang paling lazim di lakukan

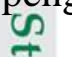
dُălam organisasi adalah kinerja pegawai, yaitu bagaimana ia melakukan segala sésuatu yang berhubungan dengan sesuatu pekerjaan atau peranan dalam : organisasi. Pengertian kinerja atau performance merupakan gambaran mengenai tingkat pencapaian pelaksanaan suatu program kegiatan atau kebijakan dalam 娄 mewujudkan sasaran, tujuan visi dan misi organisasi yang di tuangkan melalui क.

perencanaan strategi suatu organisasi. Arti kata kinerja berasal dari taka-kata job 욕

pêrformance dan di sebut juga actual performance atau prestasi kerja atau prestasi E sècsungguhnya yang telah di capai oleh seseorang pegawai Moeherionto (2012:69) Menurut oxfoord dictionary, kinerja (performance) merupakan suatu 


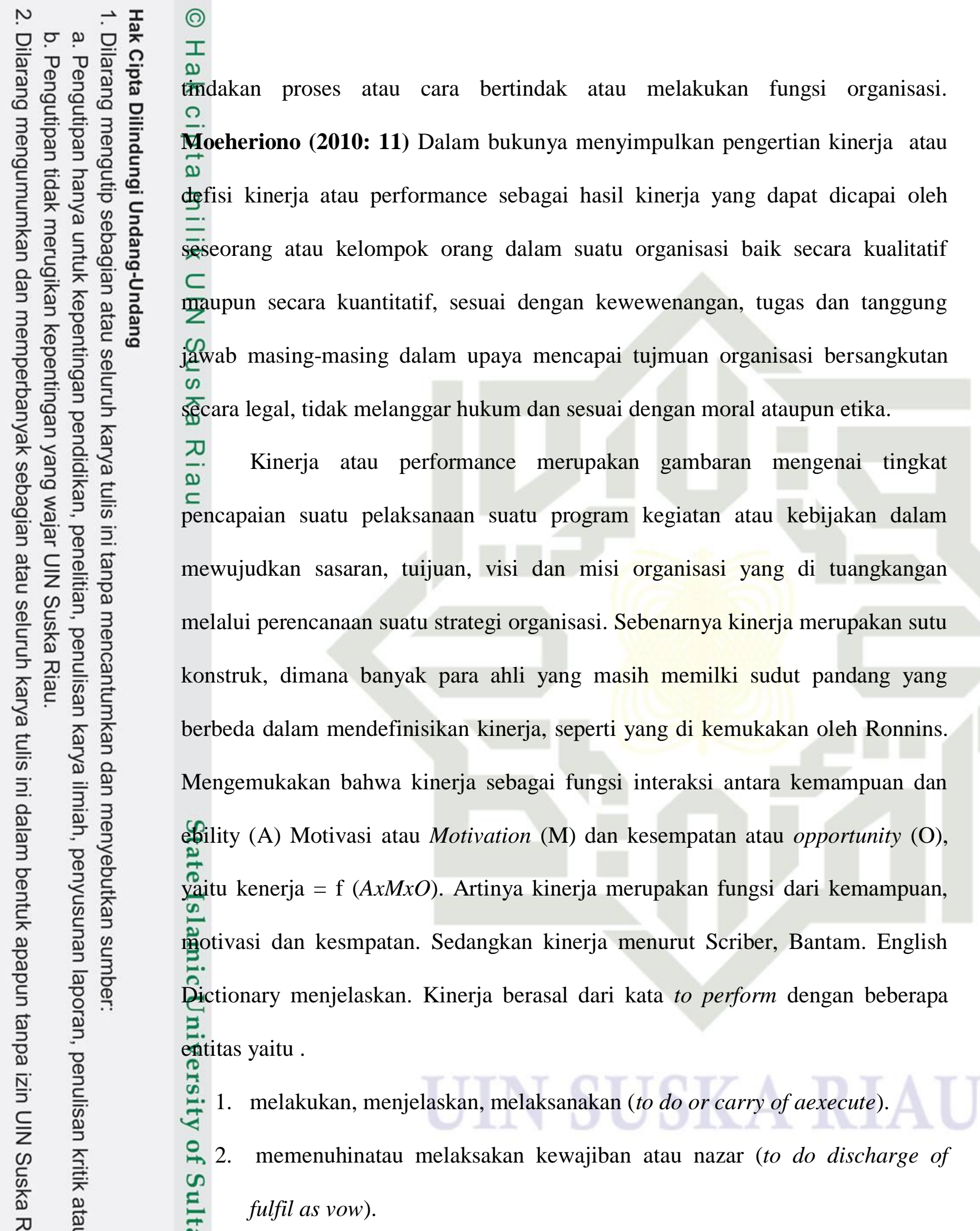




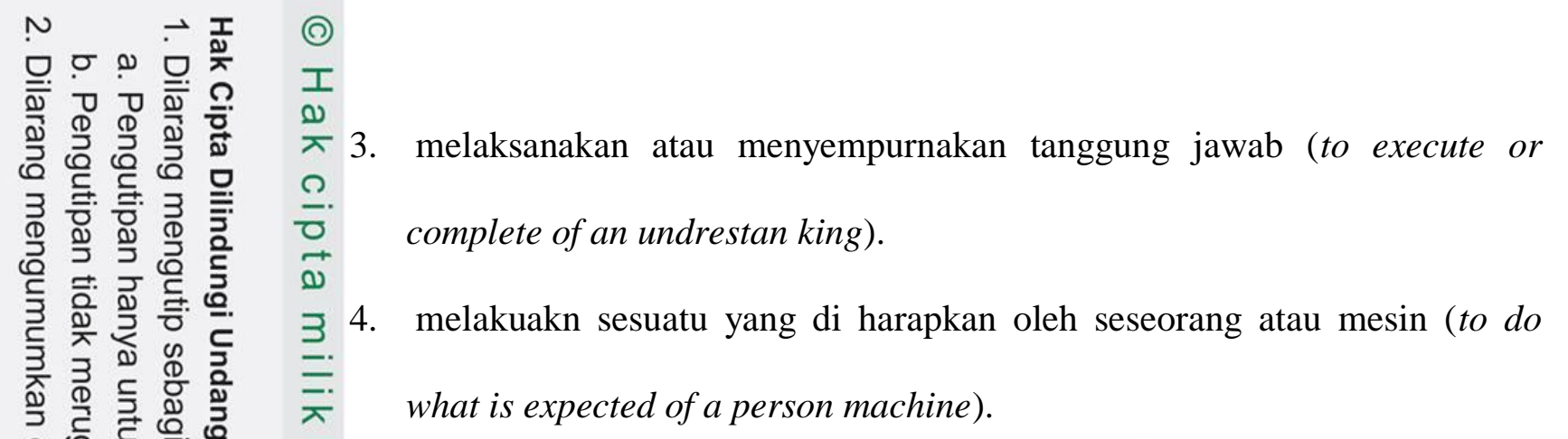

Moeharianto, (2012:95) Kinerja sebagai hasil-hasil fungsi pékerjaan/kegiatan seseorang atau kelompok dalam suatu kegiatan organisasi os Xẩng dipengaruhi oleh berbagai faktor untuk mencapai tujuan organisasi dalam periode tertentu. Fungsi kegiatan atua pekerjaan yang dimaksud disini ialah (1) pelaksanaan hasil pekerjaan atau kegiatan seseorng atau kelompok yang menjadi wewenang dan tanggung jawabnya dalam suatu organisasi. Pelaksanaan hasil pekerjaan/prestasi kerja tersebut diarahkan untuk mencapai tujuan organisasi dalam jangka waktu tertentu.

Edy Sutrisno (2010: 172) menyimpulkan kinerja sebagai hasil kerja pegawai dilihat dari aspek kualitas, kuantitas, waktu kerja, dan kerja sama untuk mencai tujuan yang sudah di tetapkan oleh organisasi. Dari berbagai uraian diatas $\stackrel{2}{\square}$ đapat di tegaskan bahwa kinerja merupakan perbandingan hasil kerja yang क

đ్మేccapai oleh seseorang dengan standar yang telah ditentukan. Kinerja juga berarti *.

hasil yang dicapai oleh seseorang, baik kuantitas maupun kualitas dalam suatu ב ơganisasi sesuai dengan tanggung jawab yang diberikan kepadanya

疍. Menurut Afandi (2018: 83) Kinerja adalah hasil kerja yang dapat diacapi sêsorang atau kelompok orang dalam suatu perusahaan sesuai dengan wewenang os

dân tanggung jawab masing - masing dalam upaya penapaian tujuan perusahaan (2) 


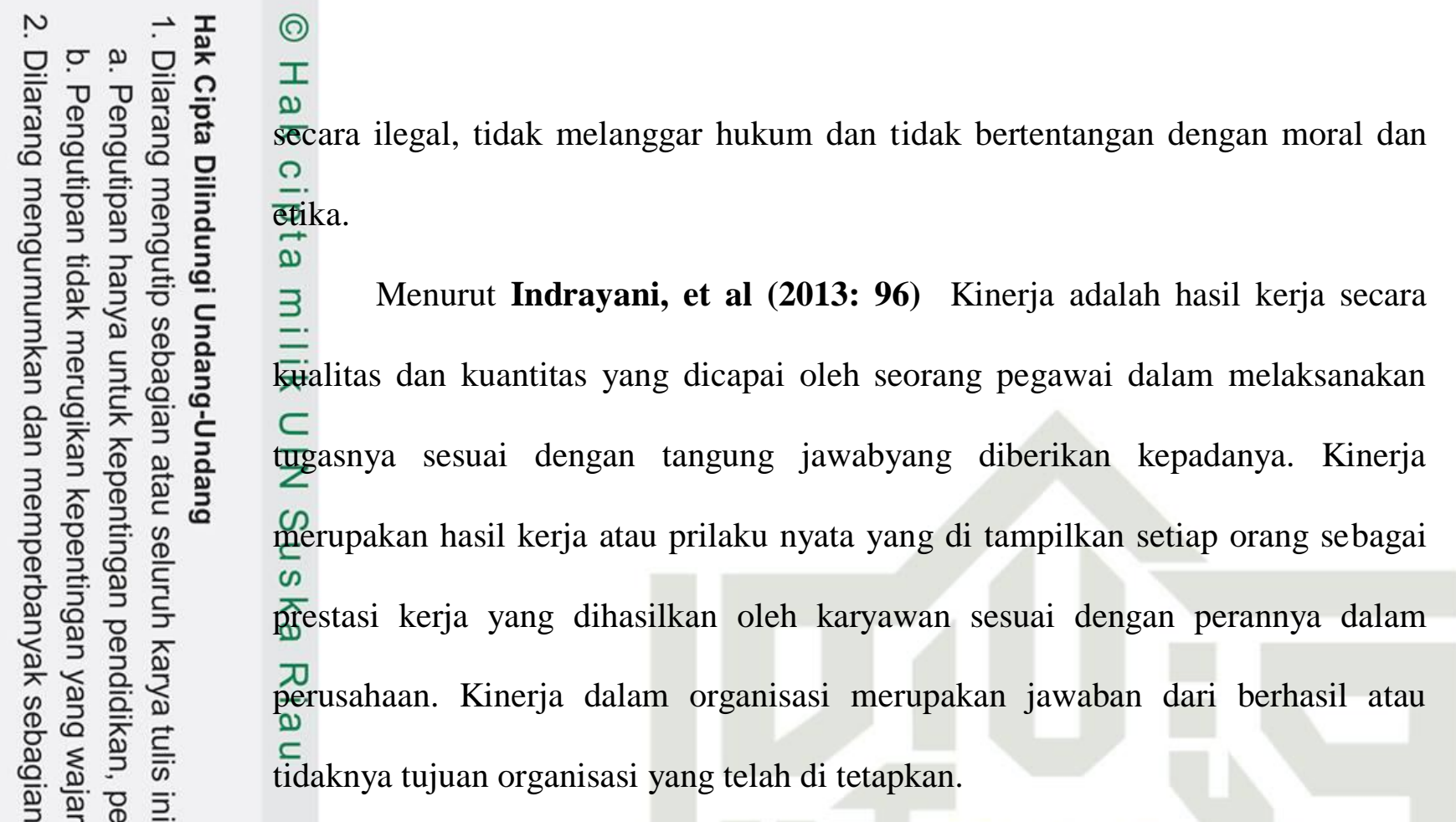

Edison (2016: 190) mengemukan bahwa kinerja adalah hasil dari suatu proses yang mengacu dan diukur selama priode waktu tertentu berdasarkan ketentuan atau kesepakatan yang telah di tetapkan sebelumnya.

Kemudian menurut Kane dan Kane dalam Suhendi dan Anggara

(2010: 186) Kinerja adalah catatan mengenai akibat yang dihasilkan pada sebuah fangsi pekerjaan ata aktivitas selama priode tententu yang berhubungan dengan $\stackrel{2}{+}$ tüjuan organisasi. Kinerja seseorang merupakan gabungan dari kemampuan, usaha क

đaำ kesempatan, yang dapat di uku dari akibat yang dihasilkan. Oleh karena itu •.

kinerja bukan menyangkut karasteristik pribadi yang ditunjukkan oleh sesorang $\exists$

melali hasil kerja yang telah atau dilakukan sesorang. Kinerja dapat pulak diart diartikan sebagai kesuksesan individu dalam melakukan pekerjaannya. Ukuran kesuksesan masing - masing karyawan bergantung pada fungsi dari pekerjaan o yäng spesifik dalam bentuk aktivitas selama kurun waktu tertentu. Dengan kata ? 
läin ukuran kesuksesan kinerja tersebut didasarkan pada ukuran yang berlaku dan ก. đisesuaikan dengan jenis pekerjaanya.

ब)

$3 \quad$ Menurut Kasmir (2016: 182) kinerja adalah hasil kerja dan prilaku kerja Fang telah dicapai dalam menyelesaikan tugas - tugas dan tanggung jawab yang $\underset{\text { di }}{\subset}$ berikan dalam suatu priode tertentu.kinerja juga diaartikan sebagai suatu pelaksananaan fungsi - fungsi yang di tuntut dari sesorang. Kinerja juga dikatakan os S్థbagai suatu perbuatan, suatu prestasi, suatu unujk keterampilan sesorang dalam

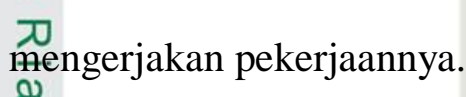

()

Pengertian Kinerja yang di kemukahkan oleh parah ahli manajemen sumberdaya manusia, kinerja dapat di didefinsikan, kinerja adalah hasil kerja dan prilaku kerja dari pelaksanan tugas yang telah dicapai dalam menyelesaikan tugas - tugas dan tanggung jawab yang mengacu dan di ukur selama priode tertentu.

\subsubsection{Faktor - Faktor yang Mempengaruhi Kinerja}

Banyak hal faktor - faktor yang mempenagruhi kinerja sala satunya dikemukakan oleh Wirawan (2012: 6) Kinerja dapat di pengaruhi dari 3 faktor yaitu :

1. Faktor Internal Pegawai yaitu faktor - faktor dari dalam diri pegawai yang merupakan faktor bawaan lahir yang diperoleh ketika dia berkembang. Yaitu terdiri dari bakat dan sifat pibadi, kreativitas, pengetahuan dan keterampilan, kompetensi, pengalaman kerja, keadaan fisik, keadaan psikologi dan prilaku kerja karyawan yaitu terdiri dari: etos kerja, disiplin kerja, motivasi kerja, semangat kerja, sikap kerja, stress kerja, keterlibatan kerja, kepemimpinan, kepuasan kerja, keloyalan. 


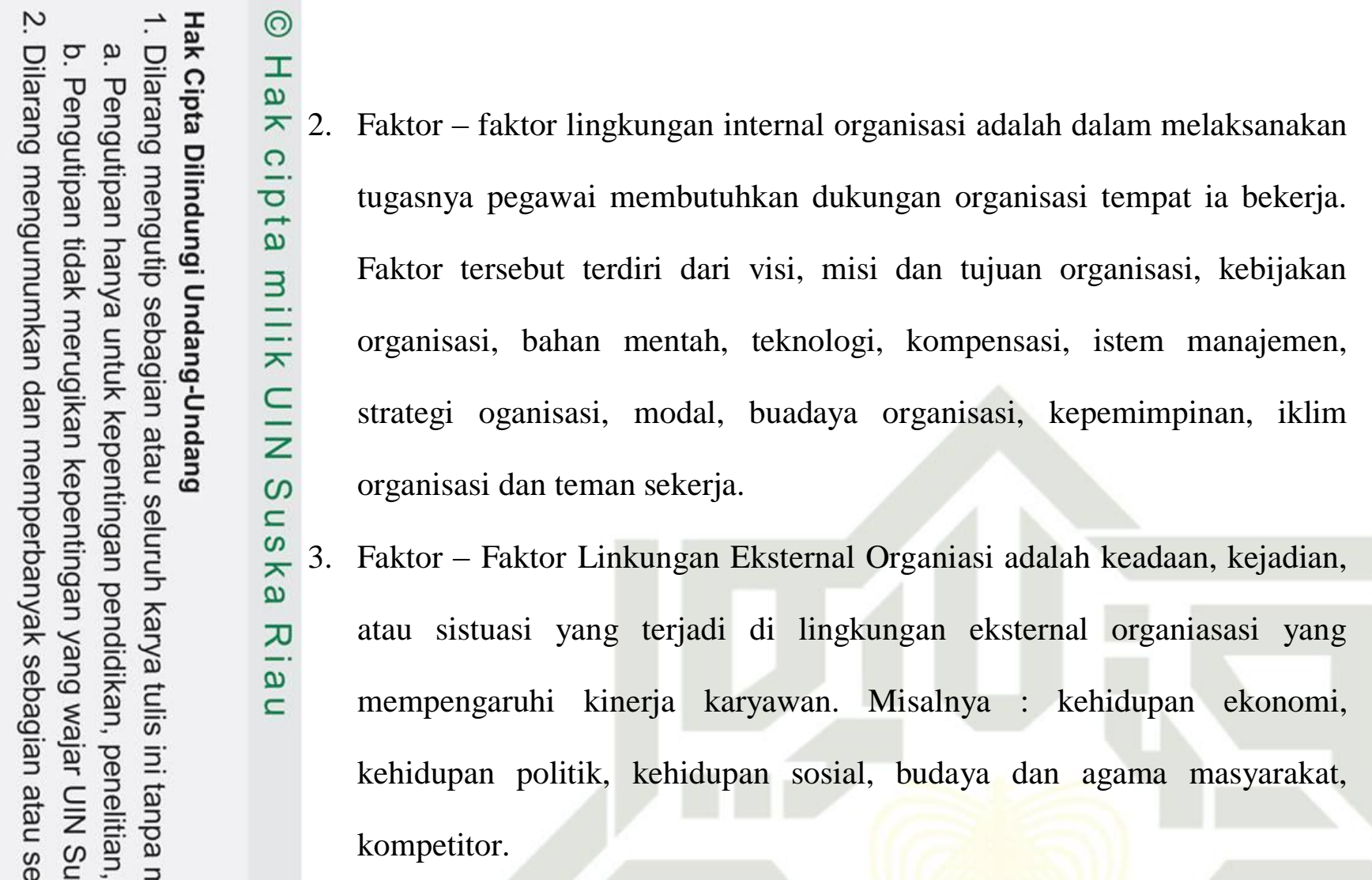

Menurut Kasmir (2016: 189) Faktor - faktor yang mempengaruhi kinerja adalah sebagai berikut :

1. Kemampuan dan keahlian

Merupakan kemampuan atau skill yang dimiliki seseorang dalam mealkukan suatu pekerjaan. Semakin memiliki kemampuan dan keahlian maka akan dapat menyelesaikan pekerjaan secara benar sesuai dengan yang di tetapkan.

2. Pengetahuan

Maksudnya adalah pengetahuan tentang pekerjaan. Sesorang yang memiliki pengetahuan tentang pekerjaan secara baik akan memberikan hasil pekerjan yang baik, demikian pulak sebaliknya. 
ㅈ. Rancangan kerja

Merupakan rancanga pekerjaan yang akan memudahkan karyawan

4. Keperibadian

Yaitu kepribadian seseorang atau karakter yang di miliki sesorang.

Setiap orang memiliki kepribadian atau krakter yang berbeda satu sama lainnya. Sesorang yang memiliki kepribadian atau krakter yang baik akan dapat melakukan pekerjaan secara sungguh - sungguh penuh tanggung jawabsehingga hasil pekerjaannya juga baik.

5. Motivasi kerja

Motivasi merupakan dorongan bagi seseorang untuk melakukan pekerjaan. Jika karyawan memiliki dorongan yang kuat dari dalam dirinya atau dorongan dari luar dirinya maka karyawan akan terangsasng atau terdorong untuk melakukan sesuatu dengan baik.

Kepemimpinan

Kepemimpinan merupakan prilaku seseorang pemimpin dalam mengatur dan mengelolah dalam memerintah bawahannya untuk mengerjakan sesuatu tugas dan tanggung jawab yang di berikannya

7. Gaya kepemimpinan

Merupakan gaya atau sikap seorang pemimpin dalam mengatur, mengelola dan memerintah bawahannya untuk mengerjakan sesuatu tugas dan tanggung jawab yang di berikannya. 


\section{.}

8. Budaya organisasi

Merupakan kebiasaan - kebiasaan atau norma - norma yang berlaku dan yang dimiliki oleh suatu organisasi atau perusahaan. Kebiasaan - kebiasaan atau norma - norma ini mngatur hal - hal yang berlaku dan di terima seacara umum serta harus di patuhi oleh segenap anggota suatu perusahaan atau organisasi.

9. Kepuasan kerja

Suatu perasaan senag atau gembira atau perasaan suka sesorang sebelum dan setelah melakukan suatu pekerjaan. Jika karyawan merasa senang atau gembira atau suka untuk bekerja, maka hasil pekerjaannya punakan berhasil baik.

10. Lingkungan kerja

Merupakan suasana atau kondisi disekitasr lokasi tempat bekerja. Lingkungan kerja dapat berupa ruangan, layout, sarana, dan prasarana serta hubunga kerja denga sesama rekan kerja. Jika lingkungan kerja dapat membuat suasana nyaman dn memberikan ketenangan maka akan dapat membuat suasana kerja menjadi kondusif sehingga dapat meningkatkan hasil kerja sesorang menjadi lebih baik karena bekerja tanpa ganguan.

\section{Loyalitas}

Merupakan kesetiaan karyawan untuk tetap bekerja dan membela perusahaan dimana tempatnya bekerja. Kesetiaan ini di tunjk kan terus bekerja sungguh - sungguh sekalipun perusahan nya dalam kondisi kurang baik. 
Meruakan kepatuhan karyawan untuk menjalankan kebijakan atau peraturan perusahan dalam bekerja. Komitmen juga diartikan kepatuhan karyawan kepada janji - janji yang telah di buatnya.

13. Disiplin kerja

Merupakan usaha karyawan untuk menjalankan aktivitas aktivitas kerjanya secara sungguh - sungguh. Disiplin kerja dalam hal ini dapat berupa wakt, misalnya masuk kerja selalu tepat waktu.

Mangkuprawira dan Hubeis (2007:160) di dalam Anggereni (2017) menyebutkan bahwa kinerja karyawan dipengaruhi oleh faktor intrinsik dan ektrinsik pegawai. Faktor-faktor intrinsik yang mempengaruhi kinerja pegawai terdiri dari pendidikan, pengalaman, motivasi, kesehatan, usia, keterampilan, emosi dan spiritual. Sedangkan faktor ekstrinsik yang mempengaruhi kinerja pegawai terdiri dari lingkungan fisik dan non fisik, kepemimpinan, komunikasi Lertikal dan horizontal, kompensasi, kontrol berupa penyeliaan, fasilitas, $\stackrel{5}{4}$ pelatihan, beban kerja, prosedur kerja, system hukuman dan sebagainya.

\subsubsection{Penilaian Kinerja}

Penilaian Kinerja merupakan suatu proses organisasi dalam menilai 공

kinerja pegawai. Secara umum tujuan dari penilaian kinerja adalah memberikan $\stackrel{0}{\rightarrow}$ timbal balik kepada pegawai dalam upaya memperbaiki kerja pegawai, dan untuk $\varangle$

meningkatkan produktivitas organisasi. Secara khusus tujuan penilaian kerja $\omega$

ădalah sebagai pertimbangan keputusan organisasi terhadap pegawai nya mengenai promosi, mutasi, kenaikan gaji, pendidikan dan pelatihan ataupun 


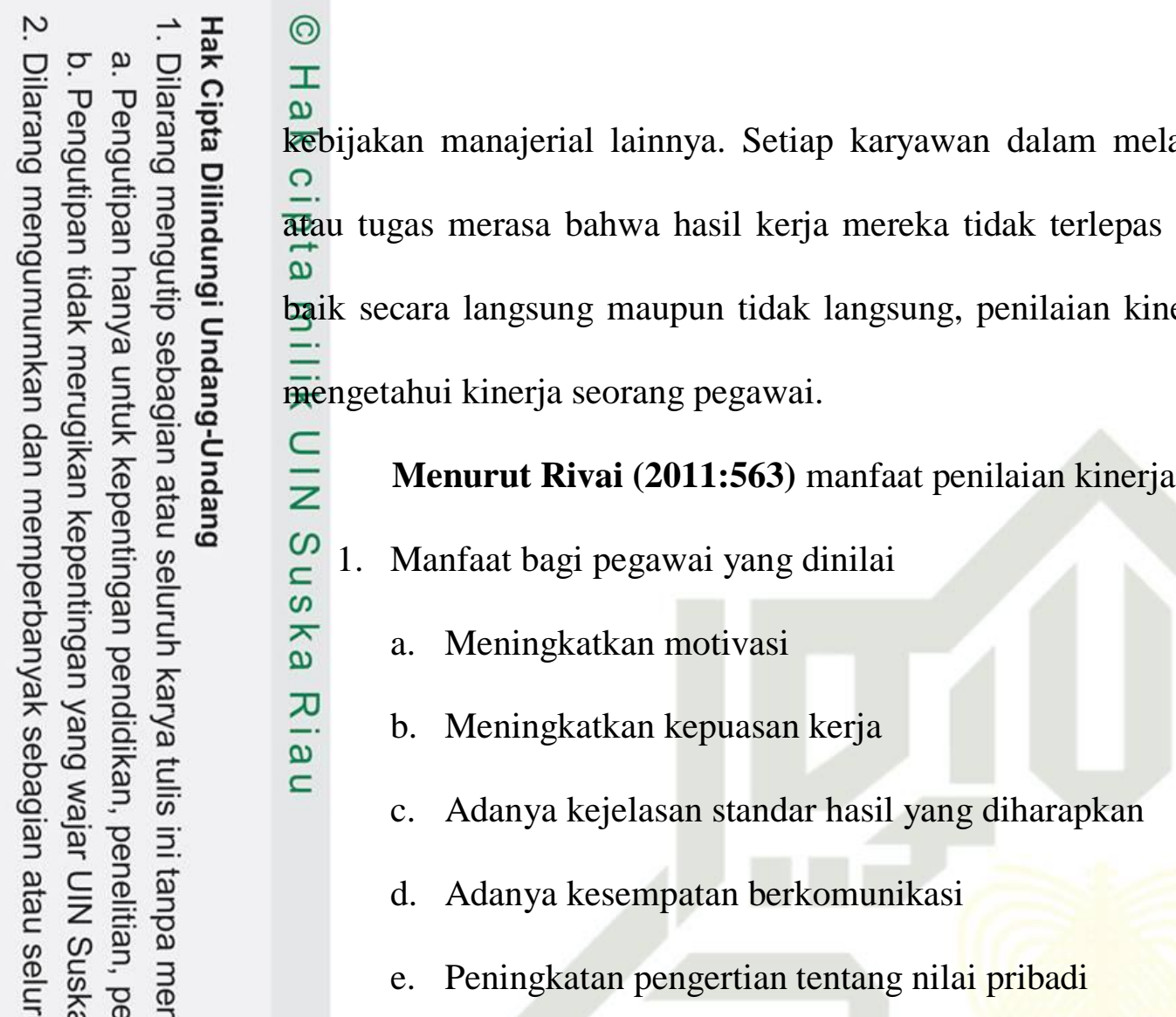

2. Manfaat bagi penilai

a. Meningkatkan kepuasan kerja

b. Kesempatan untuk mengukur dan mengidentifikasikan kecendrungan kinerja pegawai.

c. Meningkatkan kepuasan kerja baik dari para manajer ataupun pegawai.

d. Sebagai sarana meningkatkan motivasi pegawai.

e. Bisa mengidentifikasikan kesempatan untuk rotasi karyawan.

3. Manfaat bagi perusahaan

a. Perbaiki seluruh simpul unit-unit/ komitmen organisasi yangada dalam perusahaan.

b. Meningkatkan kualitas komunikasi

c. Meningkatkan motivasi karyawan secara keseluruhan. 


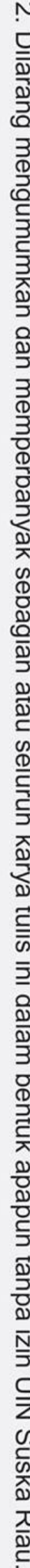

(?)

工

Q

ㄱ.

$\underset{7}{\overline{0}}$

\subsection{Indikator Kinerja}

Mangkunegara (2012: 67) dalam indikator kinerja adalah:

1. Kualitas kerja. adalah menunjukan hasil kerja yang dicapai dari segi ketepatan, ketelitian dan keterampilan

2. Kuantitas kerja adalah seberapa lama seorang pegawai bekerja dalam satu harinya. Kuantitas kerja ini dapat dilihat dari kecepatan kerja setiap pegawai itu masing-masing.

3. Pelaksanaan tugas adalah seberapa jauh karyawan mampu melakukan pekerjaannya dengan akurat atau tidak ada kesalahan.

4. Tanggung jawab Tanggung jawab terhadap pekerjaan adalah kesadaran akan kewajiban karyawan untuk melaksanakan pekerjaan yang diberikan perusahaan.

\subsubsection{Pandangan Islam tentang Kinerja}

के क

Manusia adalah makluk tuhan paling sempurna yang diciptakan Allah SîWT. Dengan segala akal dan pikirannya, manusia harus berusaha mencari solusi 邹 hidup yaitu dengan bekerja keras mengharapkan Ridho Allah SWT. Dengan $\exists$ bekerja kita akan mendaptkan balasan yang akan kita terima apabila seseorang $\stackrel{0}{3}$ memposisikan pekerjaannya dalam dua konteks yaitu kebaikan dunia dan

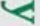

Rębaikan akhirat. Maka hal itu disebut rezeki dan berkah dan hasil pekerjaan yang $\omega$

baik adalah yang di kerjakan dengan penuh tanggung jawab dan sesuai dengan

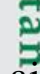
ajaran - ajaran Rasulullah SAW. 


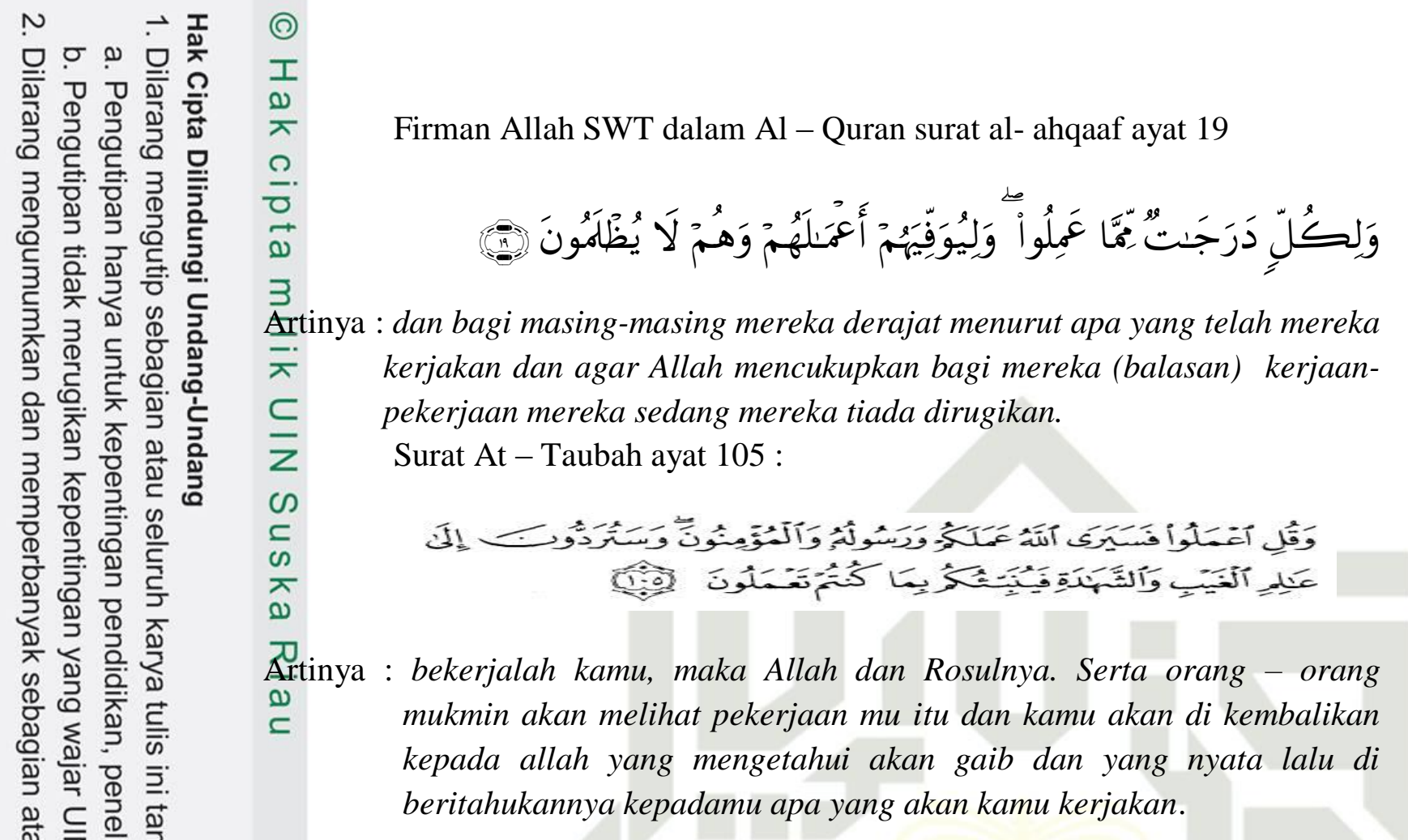

\subsection{Kepuasan Kerja}

\subsubsection{Pengertian Kepuasan Kerja}

Menurut Kamus Besar Bahasa Indonesia, kepuasan adalah perasaan senang, gembira, dan lega karena sudah terpenuhi hasrat hatinya. Sementara, kepuasan kerja didefinisikan sebagai keadaan psikis yang menyenangkan yang क्ष đị̆rasakan oleh pekerja di suatu lingkungan pekerjaan karena terpenuhinya semua क

kẹtebutuhan secara memadai. Dengan kata lain, kepuasan kerja merupakan respon B

seseorang terhadap suatu pekerjaan. Setiap manusia mempunyai kebutuhan dalam फ़่dupnya. Adanya keinginan untuk memenuhi kebutuhan itulah yang mendorong $\stackrel{9}{=}$ ṇ̃anusia melakukan berbagai aktivitas. Kebutuhan yang dimiliki manusia $\overline{4}$

sangatlah beragam. Kepuasan seseorang antara satu dengan yang lainnya akan os

bẹrbeda-beda. Jadi, kepuasan itu bersifat individual. 
Wilson Bangun (2012 ; 327) menyatakan bahwa dengan kepuasan kerja ‥

séorang pegawai dapat merasakan pekerjaannya apakah menyenangkan atau tidak () menyenangkan untuk dikerjakan.

Menurut Siagian (2013 : 295) kepuasan kerja merupakan suatu cara pandang seseorang baik yang positif maupun negatif tentang pekerjaannya. Repuasan kerja menurut Dadang (2013:15) adalah keadaan emosional yang os 页enyenangkan atau tidak menyenangkan terhadap pekerjaan, kepuasan kerja mencerminkan perasaan seeorang terhadap terhadap pekerjaannya. (2) Ricahard,(2012:312,337) menegaskan bahwa kepuasan kerja berhubungan dengan perasaan atau sikap seseorang mengenai pekerjaan itu sendiri, gaji, kesempatan promosi atau pendidikan, pengawasan, rekan kerja, beban kerja dan lain-lain.

\subsubsection{Faktor-faktor yang Mempengaruhi Kepuasan Kerja}

Menurut Edy Sutrisno (2014 : 77), faktor-fakto yang mempengaruhi kepuasan kerja adalah :

1. Kesempatan untuk maju.

Dalam hal ini ada tidaknya kesempatan untuk memperoleh pengalaman dan peningkatan kemampuan selama kerja.

2. Kemauan kerja.

Faktor ini disebut sebagai penunjang kepuasan kerja bagi pegawai. Keadaan yang aman sangat memengaruhi perasaan pegawai selama kerja. 


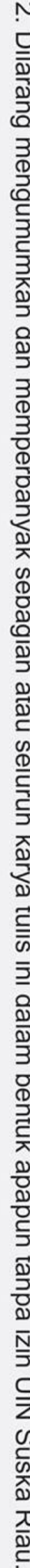

․ Gaji

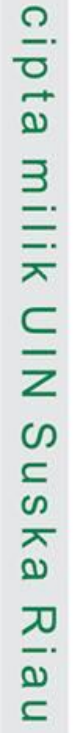

4. Perusahaan dan manajemen.

mengekspresikan kepuasan kerjanya dengan sejumlah uang yang diperolehnya.

lebih banyak menyebabkan ketidakpuasan dan jarang orang

5. Pengawasan.

Perusahaan dan manajemen yang baik adalah yang mampu memberikan situasi dan kondisi kerja yang stabil. Faktor ini yang menentukan kepuasan kerja karyawan.

Sekaligus atasannya. Supervisi yang buruk dapat berakibat absensi dan turn over

6. Faktor Instrinsik dan pekerjaan.

Atribut yang ada dalam pekerjaan mensyaratkan keterampilan tertentu. Sukar dan mudahnya serta kebanggaan akan tugas dapat meningkatkan atau mengurangi kepuasan.

7. Kondisi kerja.

Termasuk di sini kondisi tempat, ventilasi, penyiaran, kantin, dan tempat parkir.

8. Aspek sosial dalam pekerjaan.

Merupakan salah satu sikap yang sulit digambarkan tetapi dipandang sebagai faktor yang menunjang puas atau tidak puas dalam kerja. 


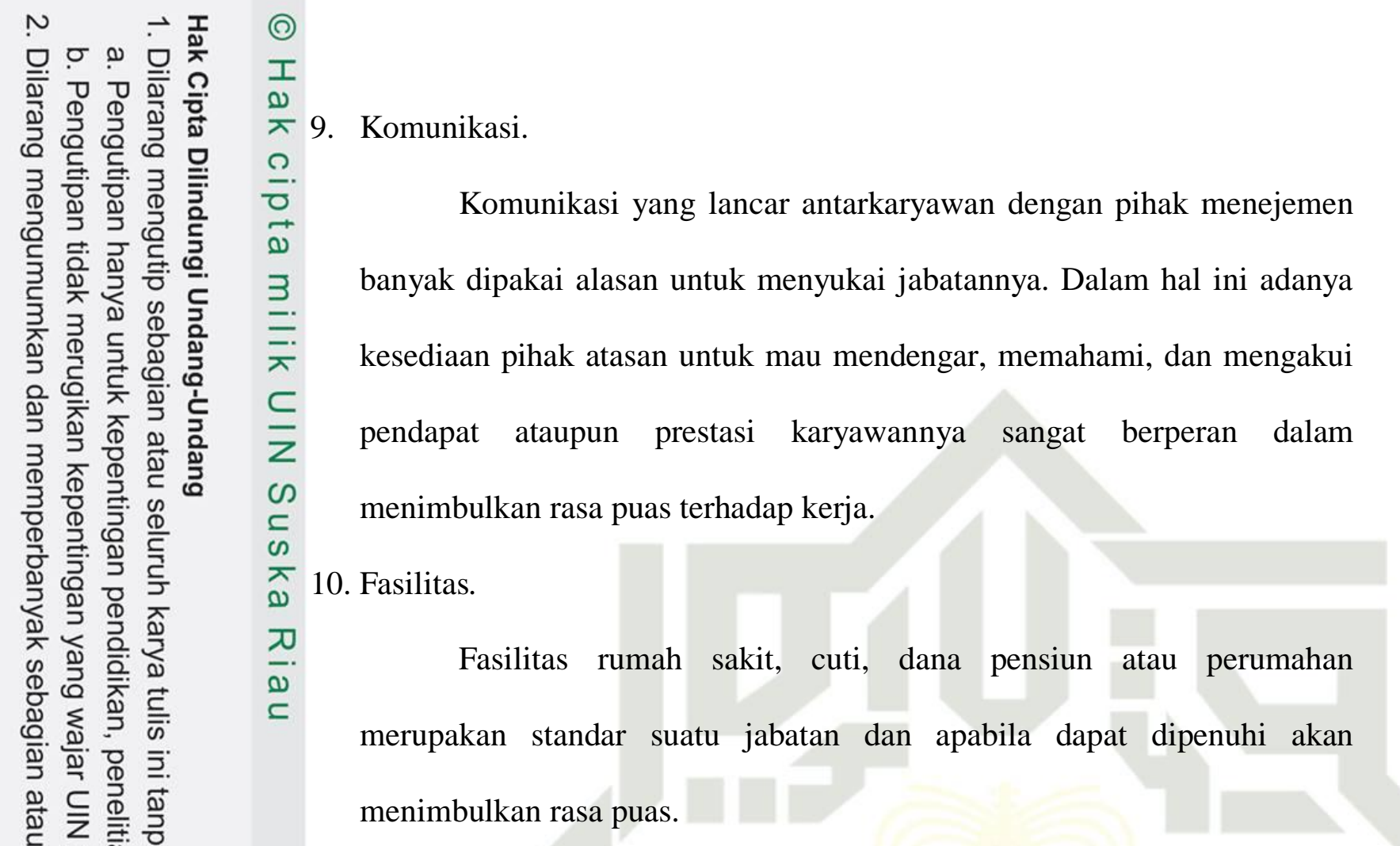

\subsubsection{Indikator Kepuasan Kerja}

Priansa, (2016:292) ia menyatakan bahwa kepuasan kerja berkaitan dengan bagaimana perasaan pegawai terhadap pekerjaannya dan terhadap berbagai macam aspek dari pekerjaan tersebut, sehingga kepuasan kerja sangat berkaitan dengan sejauh mana pegawai puas atau tidak puas dengan pekerjaannya. $\stackrel{2}{\circ}$ Dan ia dapat mengidentifikasikan indikator kepuasan kerja dari sembilan aspek क ỹaitu: 1. Gaji

Aspek ini mengukur kepuasan pegawai sehubungan dengan gaji yang diterimanya dan adanya kenaikan gaji, yaitu besarnya gaji yang diterima sesuai dengan tingkat yang dianggap sepadan. Upah dan gaji memang mempunyai pengaruh terhadap kepuasan kerja. Upah dan gaji juga menggambarkan berbagai dimensi dari kepuasan kerja. Pegawai 


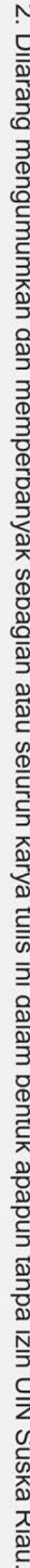

(?)

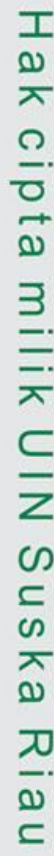

memandang gaji sebagai hak yang harus diterimanya atas kewajiban yang sudah dilaksanakannya.

2. Promosi

Aspek ini mengukur sejauh mana kepuasan pegawai sehubungan dengan kebijaksanaan promosi dan kesempatan untuk mendapatkan promosi. Promosi atau kesempatan untuk meningkatkan karier juga memberikan pengaruh terhadap kepuasan kerja pegawai.

Pegawai akan melihat apakah organisasi memberikan kesempatan yang sama kepada setiap pegawainya untuk mendapatkan kenaikan jabatan ataukah hanya diperuntukkan bagi sebagian orang saja. Kebijkasanaan promosi ini harus dilakukan secara adil, yaitu setiap pegawai yang melakukan pekerjaan dengan baik mempunyai kesempatan yang sama untuk promosi.

3. Supervisi (hubungan dengan atasan)

Aspek ini mengukur kepuasan kerja seseorang terhadap atasannya. Pegawai lebih menyukai bekerja dengan atasan yang bersikap mendukung, penuh perhatian, hangat dan bersahabat, memberi pujian atas kinerja yang baik dari bawahan, mendengar pendapat dari bawahan, dan memusatkan perhatian kepada pegawai (employed centered) dari pada bekerja dengan pimpinan yang bersifat acuh tak acuh, kasar, dan memusatkan dirinya kepada pekerjaan (job centered). 


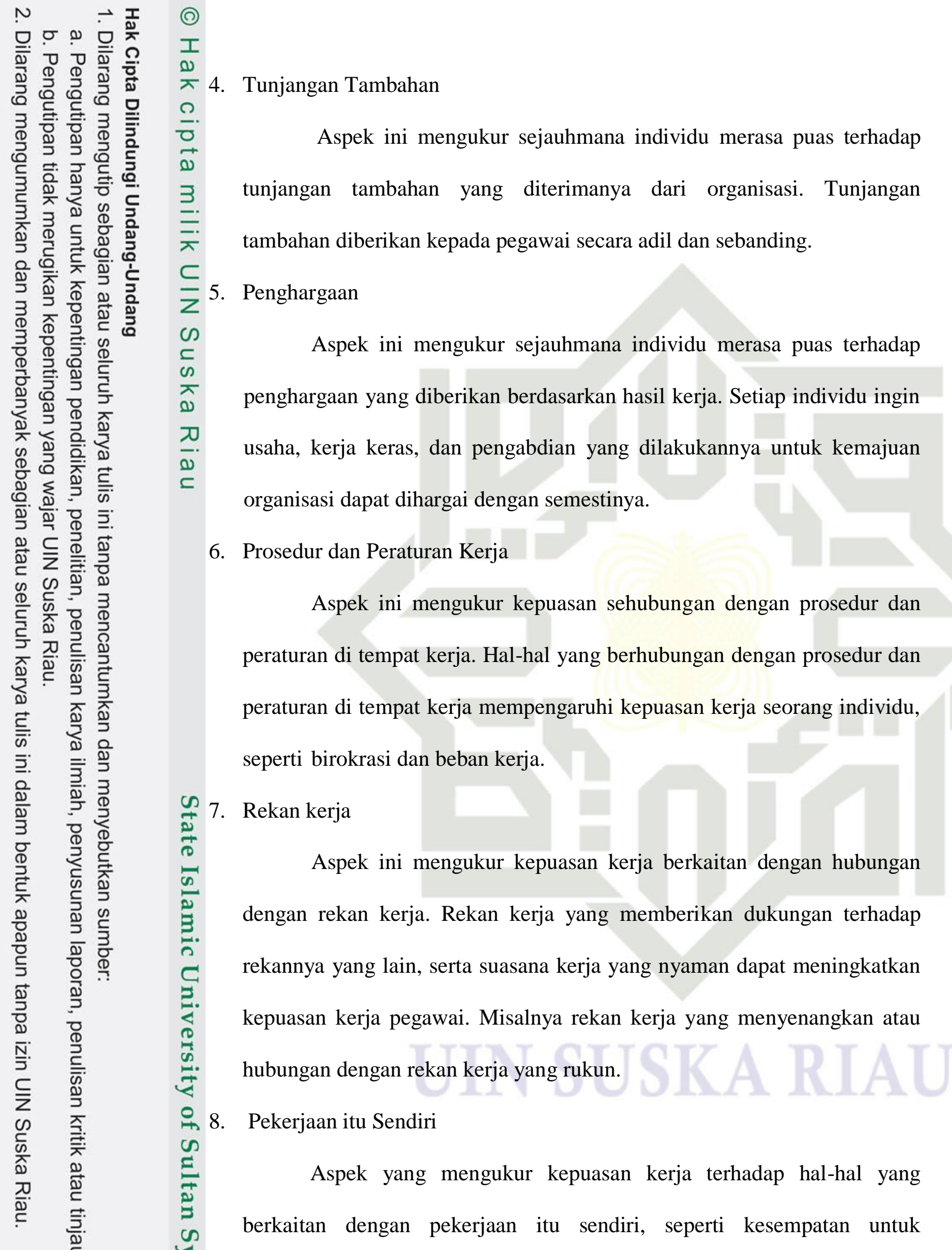




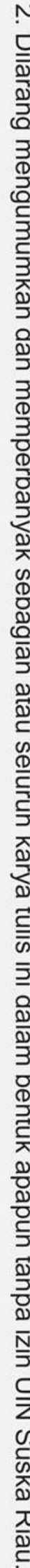

()

正

$\frac{\pi}{2}$

ㄱ.

$\frac{7}{0}$

()

ב.

둣 9. Komunikasi

Aspek ini mengukur kepuasan yang berhubungan dengan komunikasi yang berlangsung dalam pekerjaan. Dengan komunikasi yang berlangsung lancar dalam organisasi, pegawai dapat lebih memahami tugas-tugasnya dan segala sesuatu yang terjadi di dalam organisasi.

berekreasi dan variasi dari tugas, kesempatan untuk menyibukkan diri, peningkatan pengetahuan, tanggung jawab, otonomi, pemerkayaan pekerjaan, dan kompleksitas pekerjaan.

\section{$\subset$}

2. Menyuarakan (Voice)

Ketidakpuasan kerja diungkapkan dengan meninggalkan pekerjaan, termasuk mencari pekerjaan lain (turnover)

Ketidak puasan kerja diungkapkan melalui usaha aktif dan konstruktif untuk memperbaiki kondisi, termasuk memberikan saran perbaikan, mendiskusikan masalah dengan atasannya.

3. Mengabaikan (Neglect)

Ketidakpuasan kerja diungkapkan melalui sikap membiarkan keadaan menjadi lebih buruk, misalnya, sering absen, datang terlambat, malas dan kinerja yang menurun. 


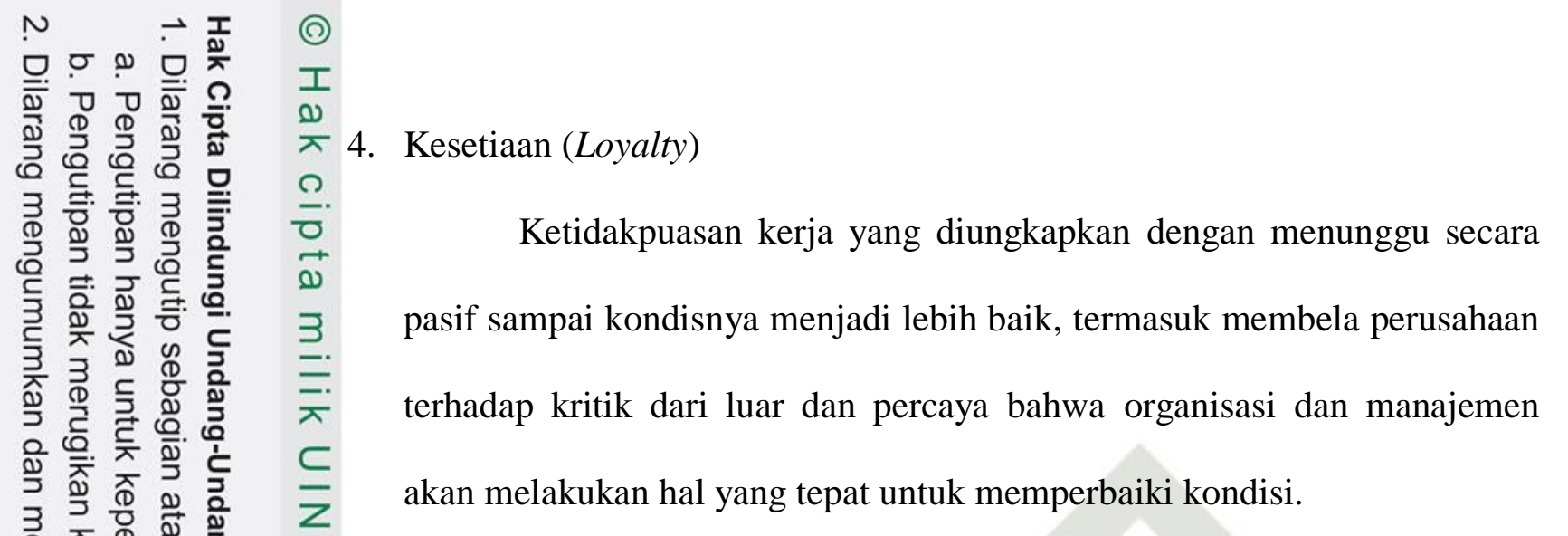

\subsubsection{Kepuasan Kerja dari Sudut Pandang Islam}

Jika kepuasan kerja dikaitkan dengan ajaran Islam maka yang muncul adalah tentang ikhlas, sabar, dan syukur. Ketiga hal tersebut dalam kehidupan kita a)

sehari-hari sangat berkaitan dengan permasalahan yang muncul dalam bekerja terutama kepuasan kerja. Bekerja dengan ikhlas, sabar dan syukur kadang-kadang memang tidak menjamin menaikkan output. Tapi sebagai proses, bekerja dengan ketiga aspek tersebut memberikan nilai tersendiri. Dengan bekerja secara ikhlas yang disertai dengan sabar dan syukur maka ada nilai satisfaction tertentu yang diperoleh, yang tidak hanya sekedar output. Ketika pekerjaan selesai, maka ada kepuasan yang tidak serta merta berkaitan langsung dengan output yang diperoleh. $\stackrel{2}{2}$

Hal ini sesuai dengan firman Allah dalam surat Ibrahim ayat 7

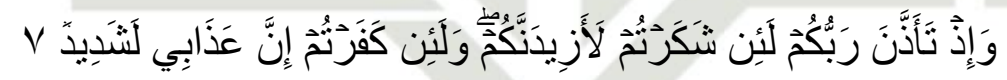

yang artinya, "Sesungguhnya jika kamu bersyukur, pasti Kami akan măenambah (nikmat) kepadamu, dan jika kamu mengingkari (nikmat-Ku), maka क. se.sungguhnya azab-Ku sangat pedih".

Bekerja dengan tidak disertai ikhlas, sabar dan syukur bisa menjadikan

OFang bermuka cemberut menyelesaikan tugas. Pekerjaan memang selesai, output $\stackrel{2}{3}$

ada, dan target bisa diperoleh. Tapi keberhasilan yang diperoleh bila bekerja tidak 


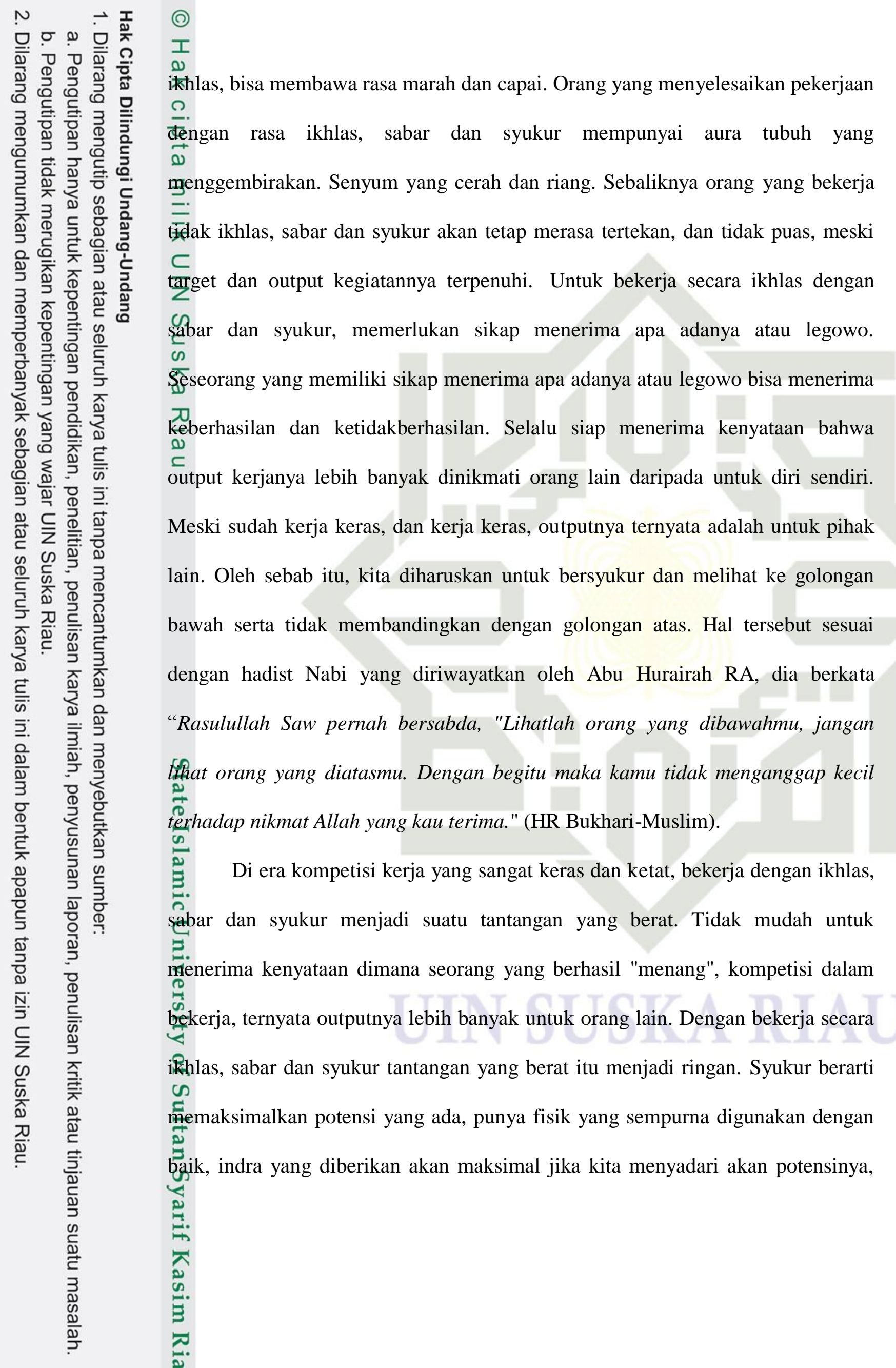


K̄ndisi sadar atas kepemilikan diri adalah konsep syukur, begitu juga kita diberi ‥

ㅍำur, kesehatan digunakan dengan baik, harta yang cukup digunakan seefektif ()

dan seefisien mungkin. Jika tidak mendapatkan itu selanjutnya adalah sabar dan i乔hlas dengan tetap memperhatikan potensi diri, memahami kondisinya, tetap

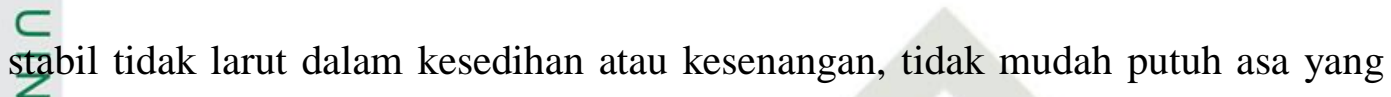
mূnengakibatkan stres atau depresi yang akan menimbulkan prilaku negatif, os

页erugikan diri sendir bahkan orang lain, jadi bukan sabar yang 'bodoh' tetapi

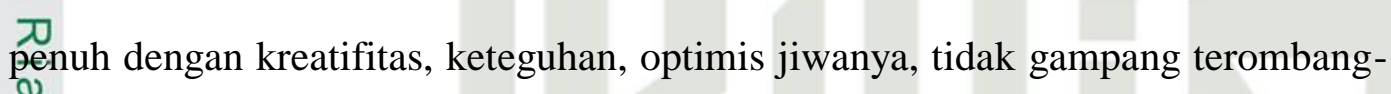
$\stackrel{1}{c}$ ambing keadaan, Itulah kesadaran kita tetap terjaga dan terbaharui yang memungkinkan untuk mengambil keputusan dan tindakan secara bijaksana walaupun dalam situasi yang sulit sekalipun.

\subsection{Komitmen Organisasi}

Komitmen organisasional bisa tumbuh disebabkan karena individu memiliki ikatan emosional terhadap perusahaan yang meliputi dukungan moral dan menerima nilai yang ada di dalam perusahaan serta tekad dari dalam diri $\stackrel{2}{\frac{0}{2}}$

üntuk mengabdi pada perusahaan.

Menurut Sutrisno (2010:292) komitmen organisasi merupakan kemauan

usaha yang tinggi untuk organisasi dan suatu keyakinan tertentu dalam ᄅ.

pénerimaan terhadap nilai-nilai organisasi. Komitmen pada organisasi tersebut jug

jugga membahas kedekatan pegawai merefleksikan kekuatan keterlibatan dan

kesetiaan pegawai pada organisasi. Komitmen organisasional dipandang sebagai w

sషّatu orientasi nilai terhadap organisasi yang menunjukan individu sangat 2.

memikirkan dan mengutamakan pekerjaan dan organisasinya. Individu akan 


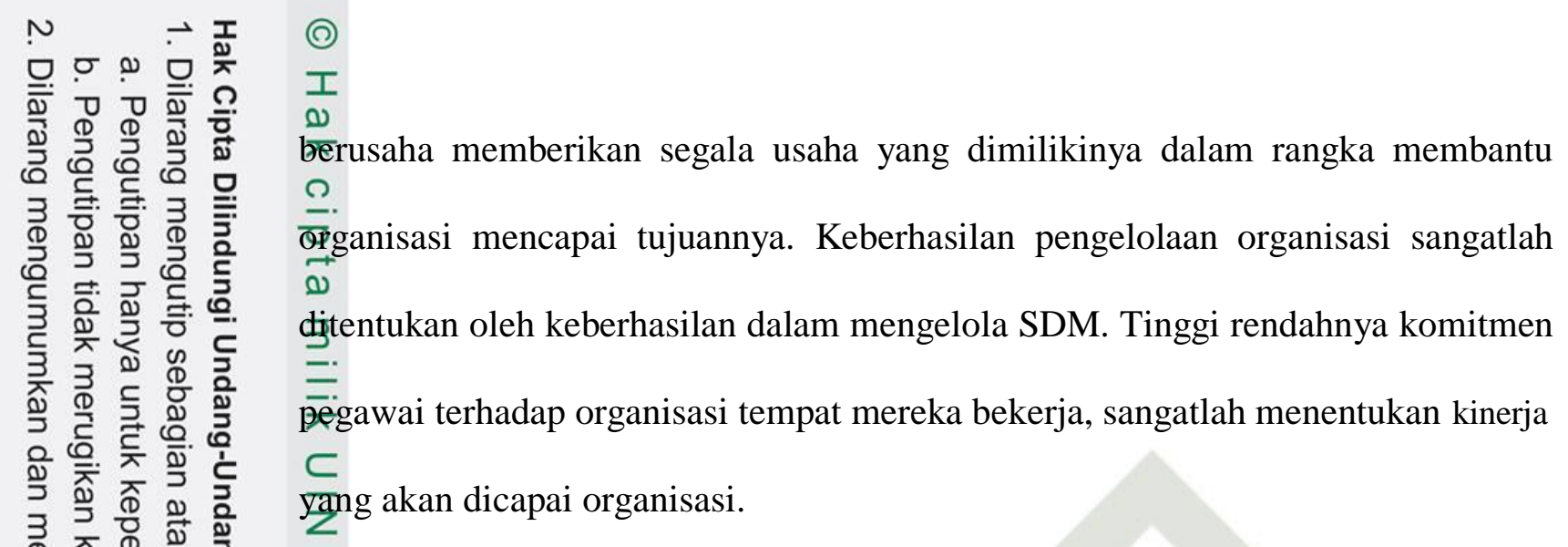

œ Kreitner (2014:165) mendefinsikan komitmen organisasi sebagai D Gkatan dimana seseorang mengenali sebuah organisasi dan terikat pada 깡 a memiliki komitmen diharapkan bisa menunjukkan kesediaan untuk bekerja lebih keras demi mencapai tujuan organisasi dan memiliki hasrat yang lebih besar untuk tetap bekerja di suatu perusahaan.

Robbins (2012:100) mengemukan komitmen organisasi adalah : "Tingkat sampai mana seseorang memihak sebuah organisasi serta tujuan-tujuan dan keinginannya untuk mempertahankan keanggotaan dalam organisasi tersebut"

() Komitmen terhadap organisasi artinya lebih dari sekedar keanggotaan formal, karena meliputi sikap menyukai organisasi dan kesediaan untuk क månengusahakan tingkat upaya yang tinggi bagi kepentingan organisasi demi :. pencapaian tujuan. Berdasarkan definisi ini, dalam komitmen organisasi tercakup כ. thinsur loyalitas terhadap organisasi, keterlibatan dalam pekerjaan, dan identifikasi क. terrhadap nilai-nilai dan tujuan organisasi.

Rendahnya komitmen mencerminkan kurangnya tanggung jawab a sëseorang dalam menjalankan tugasnya. Mempersoalkan komitmen sama dengan D mempersoalkan tanggung jawab. Kepuasaan kerja dan komitmen organisasional 


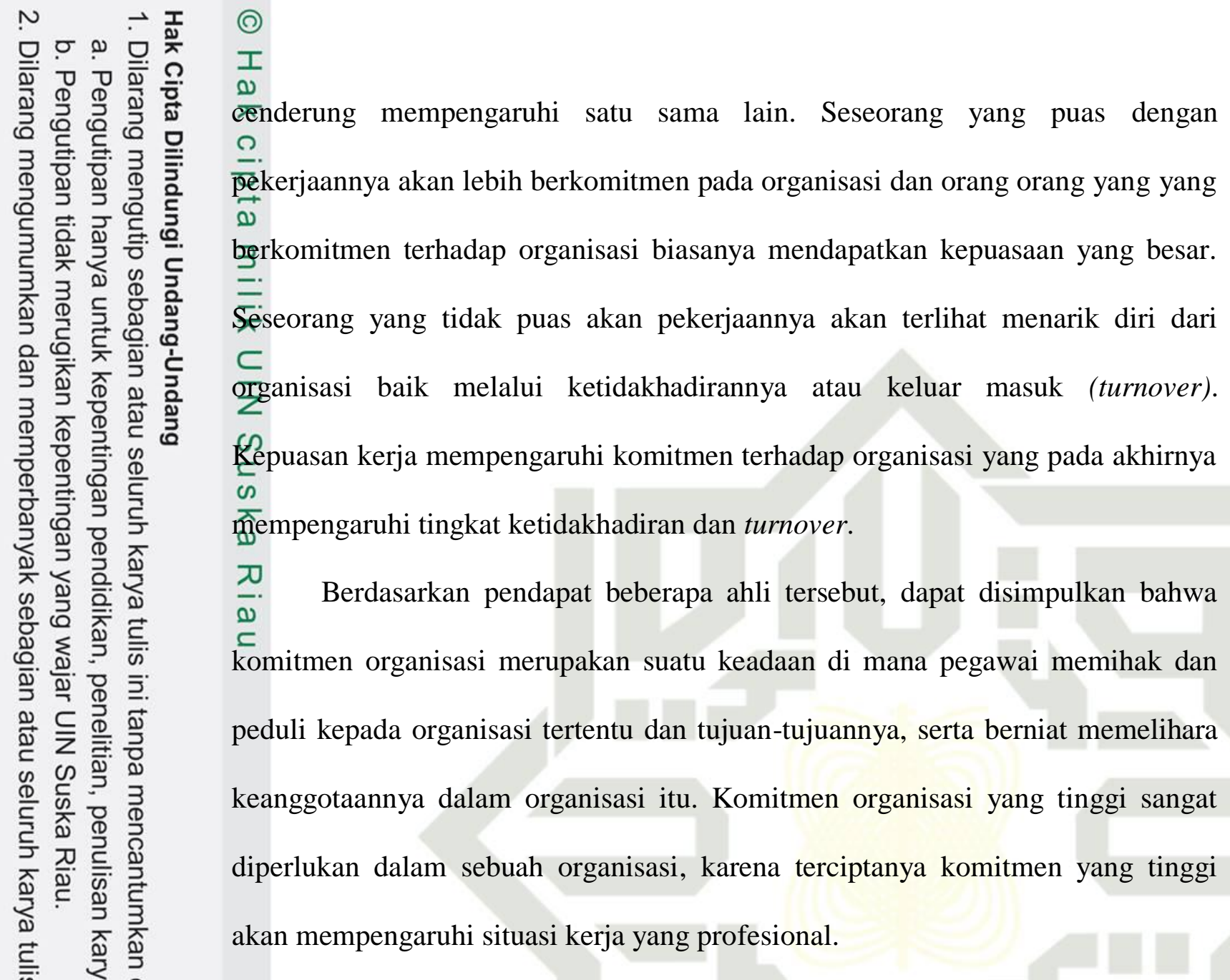

\subsubsection{Faktor-faktor yang Mempengaruhi Komitmen Organisasi}

( Menurut Lincoln (2010:156) penyebab dari komitmen organisasi ada tiga yaitu:

1. Kemauan karyawan, dilihat dari antusias dan kemauan diri pribadi sendiri. Dengan melakukan inisiatif tindakan untuk perusahaan tanpa ada perindah dari atasan.

2. Kesetiaan karyawan, sejauh mana tiap individu mempunyai komit dalam hal kesetiaan terhadap organisasi dengan tidak ada rasa pindah atau menduakan organisasi itu. 


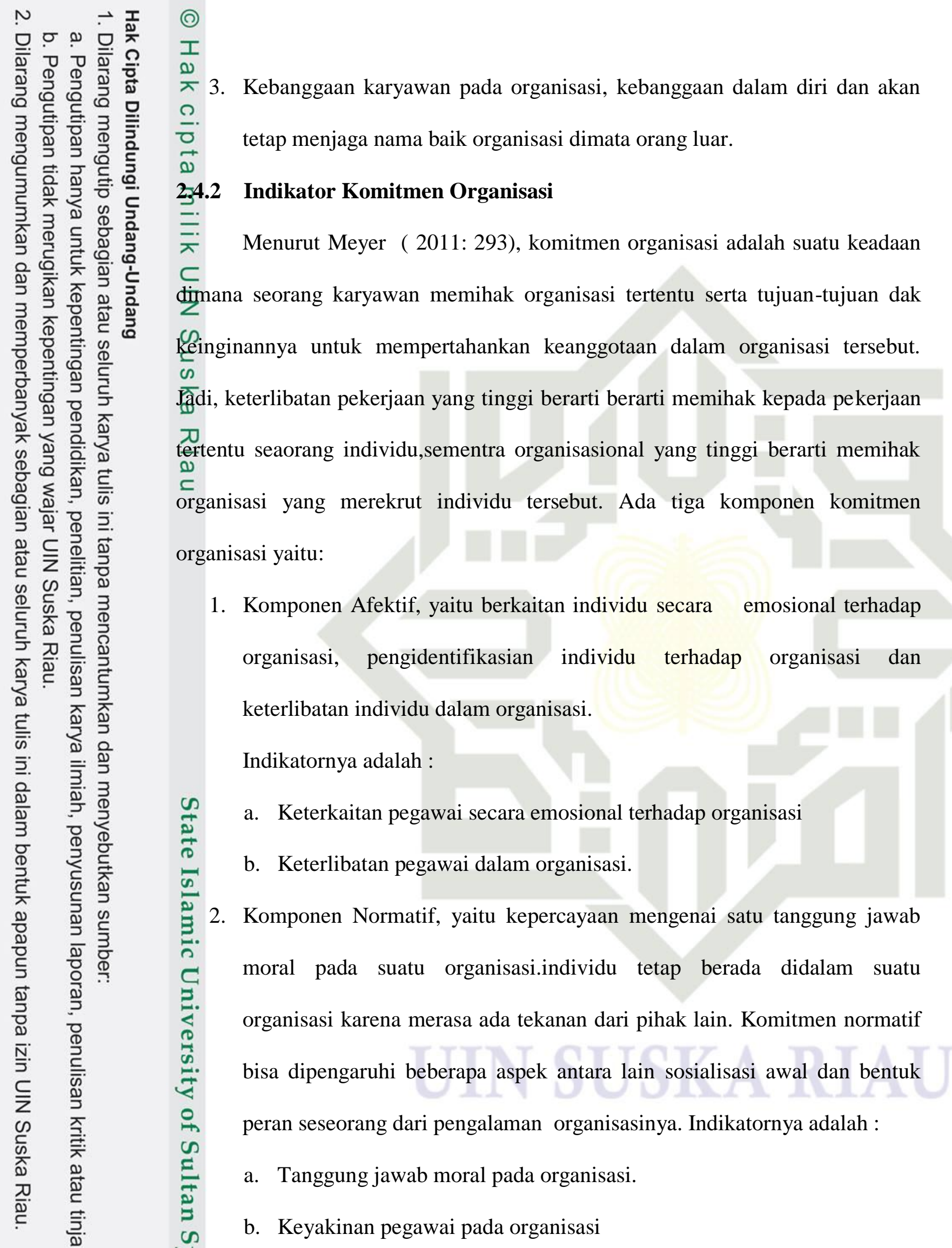


3. Komponen Continuance, yaitu kecenderungan untuk melakukan aktivitas yang sama secara konsisten berdasarkan kesadaran akan biaya atau pengorbanan yang dikeluarkan sehubungan dengan menghentikan aktivitas tersebut atau dengan kata lain merupakan komitmen yang berdasarkan kepada biaya yang ditanggung individu karena keluar dari organisasi. Komitmen continuance merujuk pada kekuatan kecenderungan seseorang untuk tetap bekerja di suatu organisasi karena tidak ada alternatif pekerjaan lain. Indikatornya adalah :

a. Kecenderungan pegawai untuk melakukan aktivitas yang sama secara konsisten

b. Kesadaran akan biaya atau pengorbanan yang dikeluarkan

\subsubsection{Dampak Komitmen Organisasi}

Menurut Sopiah (2010:166) komitmen, baik yang tinggi maupun yang rendah, akan berdampak pada:

(f) 1. Pegawai itu sendiri, misalnya terhadap perkembangan karier pegawai itu di के organisasi atau perusahaan.

2. Organisasi. yang berkomitmen tinggi pada organisasi akan menimbulkan kinerja organisasi yang tinggi, tingkat absensi berkurang, loyalitas karyawan, dan lain-lain.

Pedoman untuk Meningkatkan Komitmen Organisasional

Dessler (Luthans, 2011:148) memberikan beberapa pedoman untuk 心 meningkatkan komitmen organisasional : 


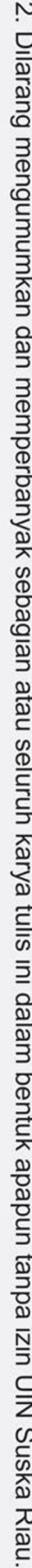

1. Commit to people-first values. Organisasi mempunyai komitmen pada nilai - nilai yang mengutamakan pada orangnya.

2. Clarify and communicate your mission. Organisasi mengklarifikasi dan mengomunikasikan misi dan ideologi, dilakukan secara kharismatik menggunakan praktik perekrutan berbasis niali; penekanan pada orientasi berbasis niali dan pelatihan; serta membangun tradisi.

Guarantee organizational justice. Organisasi menjamin keadilan organisasional. Untuk itu, organiasi mempunyai prosedur keluhan yang komprehensif dan menyelenggarakan komunikasi dua arah secara ekstensif.

3. Create a sense of community. Organisasi membangun perasaan sebagai komunitas dengan membangun homogenitas berbaisis nilai; saling berbagi; saling memanfaatkan dan kerja sama; serta hidup bersama-sama.

4. Support employee development. Organisasi mendukung pengembangan pekerja. Organisasi mempunyai komitmen untuk 32 aktualisasi mengusahakan tantangan kerja tahun pertama; memperkaya dan memberdayakan.

\section{2,4.5 Bentuk Komitmen Organisasi}

Menurut Kanter dalam Sopiah (2010:158) mengemukakan adanya tiga bentuk komitmen organisasi, yaitu:

1. Komitmen berkesinambungan (continuance commitment)

Yaitu komitmen yang berhubungan dengan dedikasi anggota dalam melangsungkan kehidupan organisasi dan menghasilkan orang yang berkorban dan berinvestasi pada organisasi. 
(2)

a)

(1)

2. Komitmen terpadu (cohesion commitment)

Yaitu komitmen anggota terhadap organisasi sebagai akibat adanya hubungan sosial dengan anggota lain di dalam organisasi. Ini terjadi karena karyawan percaya bahwa norma-norma yang dianut organisasi merupakan norma-norma yang bermanfaat.

3. Komitmen terkontrol (control commitment)

Yaitu komitmen anggota pada norma organisasi yang memberikan perilaku kearah yang diinginkannya. Norma-norma yang dimiliki organisasi sesuai dan mampu memberikan sumbangan terhadap perilaku yang diinginkan.

\subsubsection{Komitmen Organisasi dari Pandang Sudut Islam}

Terdapat dua kata bantu yang terdapat dalam al-Qur'an untuk mempelajari pengorganisasian ini. Kata tersebut adalah ( Shaff) dan ( ummat ). Penulis akan membahas dua kata tersebut satu per satu. Penulis mengidentikkan kata ( shaff ) inj dengan organisasi. Jadi organisasi menurut analisis kata ini adalah suatu क perkumpulan atau jamaah yang mempunyai sistem yang teratur dan tertib untuk $\stackrel{\infty}{m e n c a p a i ~ t u j u a n ~ b e r s a m a . ~ D a l a m ~ s u r a h ~ a l-S h a f f ~ a y a t ~} 4$ dikemukakan:

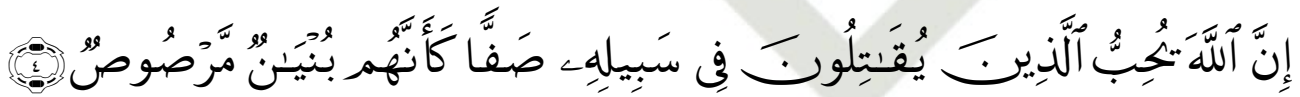

Airtinya: Sesungguhnya Allah menyukai orang yang berperang dijalan-Nya dalam - barisan yang teratur seakan-akan mereka seperti suatu bangunan yang क. tersusun kokoh.

Maksud dari shaff disitu menurut al-Qurtubi adalah menyuruh masuk os

đạlam sebuah barisan (organisasi) supaya terdapat keteraturan untuk mencapai

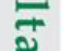

ttijuan.Dalam sebuah hadits diterangkan: Artinya: "Sesungguhnya Allah क

mencintai orang yang jika melakukan suatu pekerjaan dilakukan dengan "tepat, 政. 
(1)

terarah dan tuntas“. Suatu pekerjaan apabila dilakukan dengan teratur dan terarah, $\Omega$

M̄aka hasilnya juga akan baik. Maka dalam suatu organisasi yang baik, proses $\overrightarrow{0}$

jugga dilakukan secara terarah dan teratur atau. Menurut al-Baghawi maksud dari 产at di atas adalah manusia tetap pada tempatnya dan tidak bergoyah dari tempat

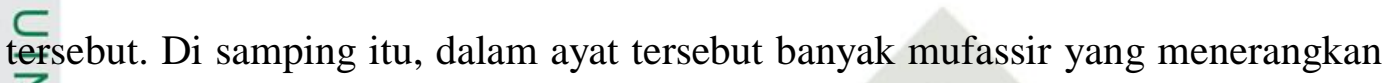
Z

6ahwa ayat tersebut adalah barisan dalam perang. Maka ayat tersebut C mengindikasikan adanya tujuan dari barisan perang yaitu berupaya untuk a)

melaksanakan kewajiban yaitu jihad di jalan allah dan memperoleh kemenangan. a)

Đalam penafsiran versi lain, dikemukakan bahwa ayat tersebut menunjukkan barisan dalam shalat yang memiliki keteraturan.

Dalam sebuah hadits diterangkan bahwa apabila seseorang hanya mementingkan kepentingan sepihak dan melakukan tugas serta tanggung jawabnya dengan asal-asalan. Hadits yang menerangkan tentang kekalahan umat Islam dalam perang Uhud menunjukkan bahwa apabila seseorang tidak melaksanakan anggotanya sebagai bagian dari organisasi perang, maka akibatnya $+$

adalah organisasi tersebut mengalami kekalahan. Jadi dalam sebuah organisasi

hărus terjadi koordinasi yang baik dan tidak boleh terjadi penyalahgunaan క Wewenang.

Dalam ayat lain diterangkan:

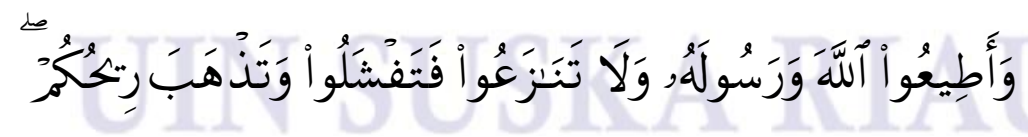

Artinya : Dan taatlah kepada Allah dan Rasul-Nya dan janganlah kamu berbantah-bantahan, yang menyebabkan kamu menjadi gentar dan hilang kekuatanmu dan bersabarlah. Sesungguhnya Allah beserta orang-orang yang sabar. (Q.S. al-Anfal: 46) 


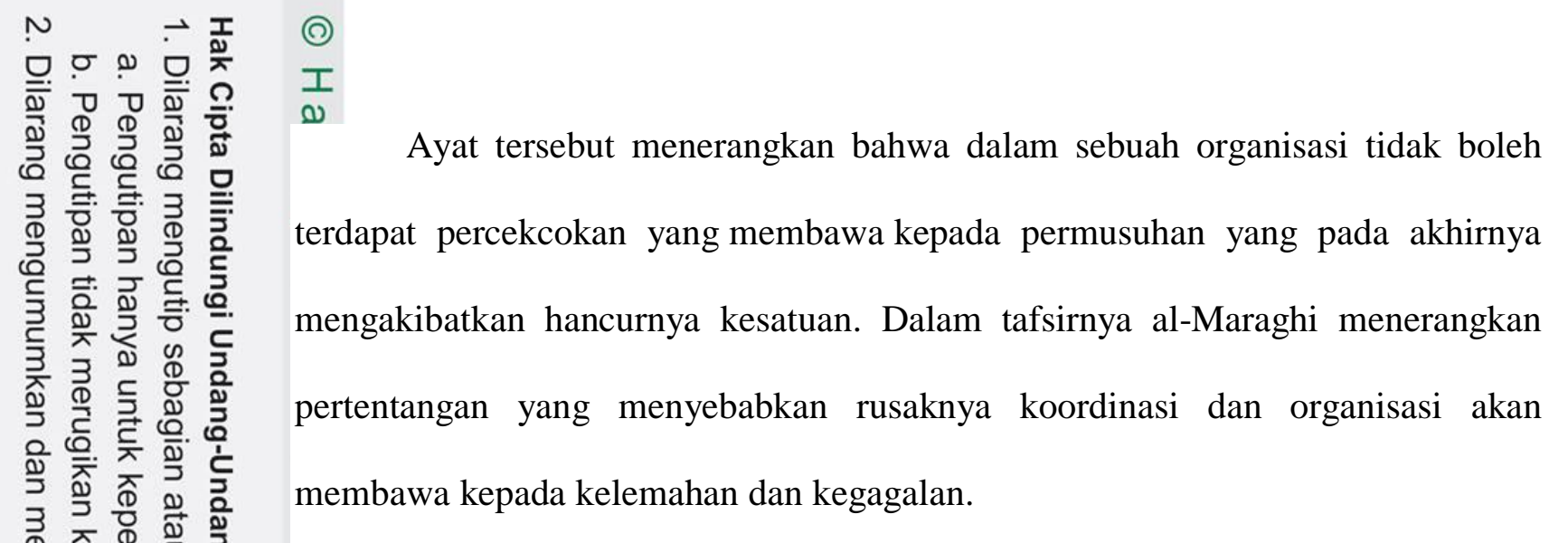

Berorganisasi sangat penting dan merupakan hal yang pokok untuk menjalankan sebuah manajemen. Al-Qur'an menjelaskan:

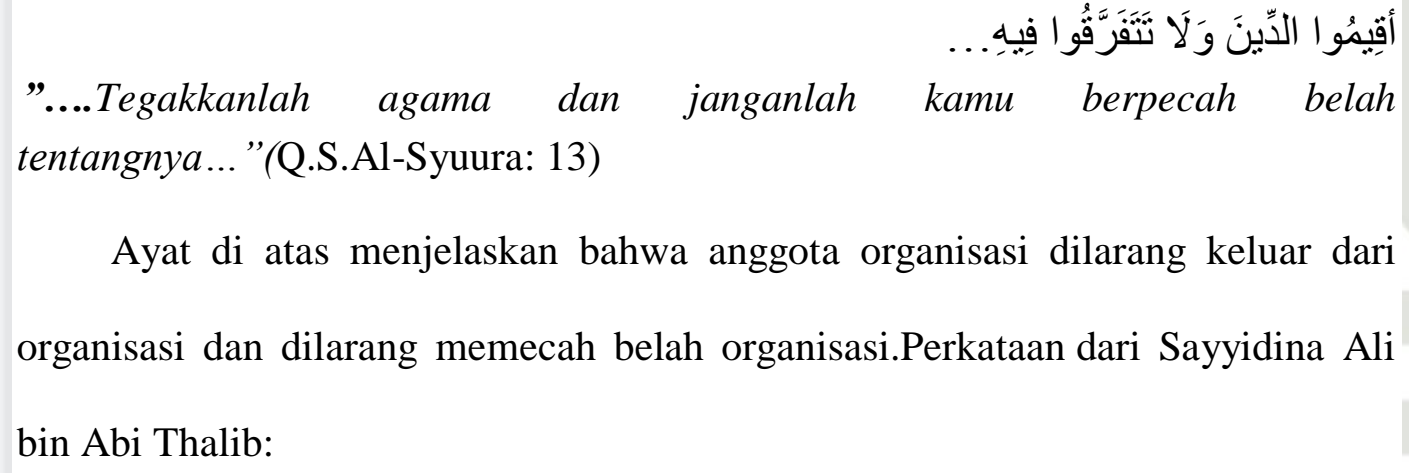

Ayat di atas menjelaskan bahwa anggota organisasi dilarang keluar dari organisasi dan dilarang memecah belah organisasi.Perkataan dari Sayyidina Ali bin Abi Thalib:

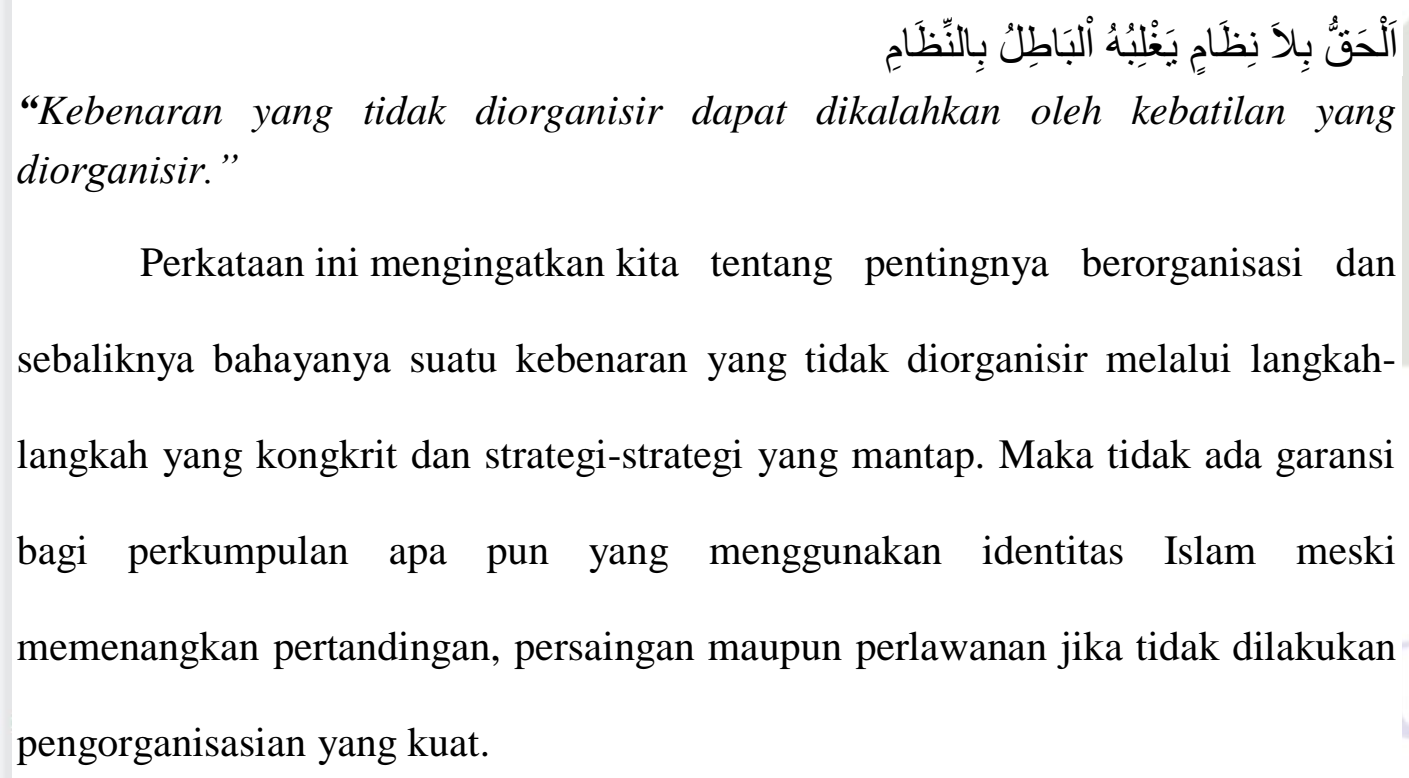
diorganisir."

Perkataan ini mengingatkan kita tentang pentingnya berorganisasi dan sebaliknya bahayanya suatu kebenaran yang tidak diorganisir melalui langkahlangkah yang kongkrit dan strategi-strategi yang mantap. Maka tidak ada garansi bagi perkumpulan apa pun yang menggunakan identitas Islam meski memenangkan pertandingan, persaingan maupun perlawanan jika tidak dilakukan pengorganisasian yang kuat. 


\section{Penelitian Terdahulu}

?.

Penelitian terdahulu yang digunakan penulis adalah sebagai dasar dalam ()

penyusunan penelitian. Tujuannya adalah untuk mengetahui hasil yang telah 二.

Filakukan oleh peneliti terdahulu, sekaligus sebagai perbandingan dan gambaran yang dapat mendukung kegiatan penelitian berikutnya yang sejenis. Kajian yang đIgunakan yaitu mengenai kepuasan kerja, komitmen organisasi, yang os

bु్ renengaruh terhadap kinerja pegawai. Berikut ini adalah tabel perbandingan pen penelitian terdahulu yang mendukung penelitian penulis.

\section{(}

Tabel 2.1 Penelitian Terdahulu

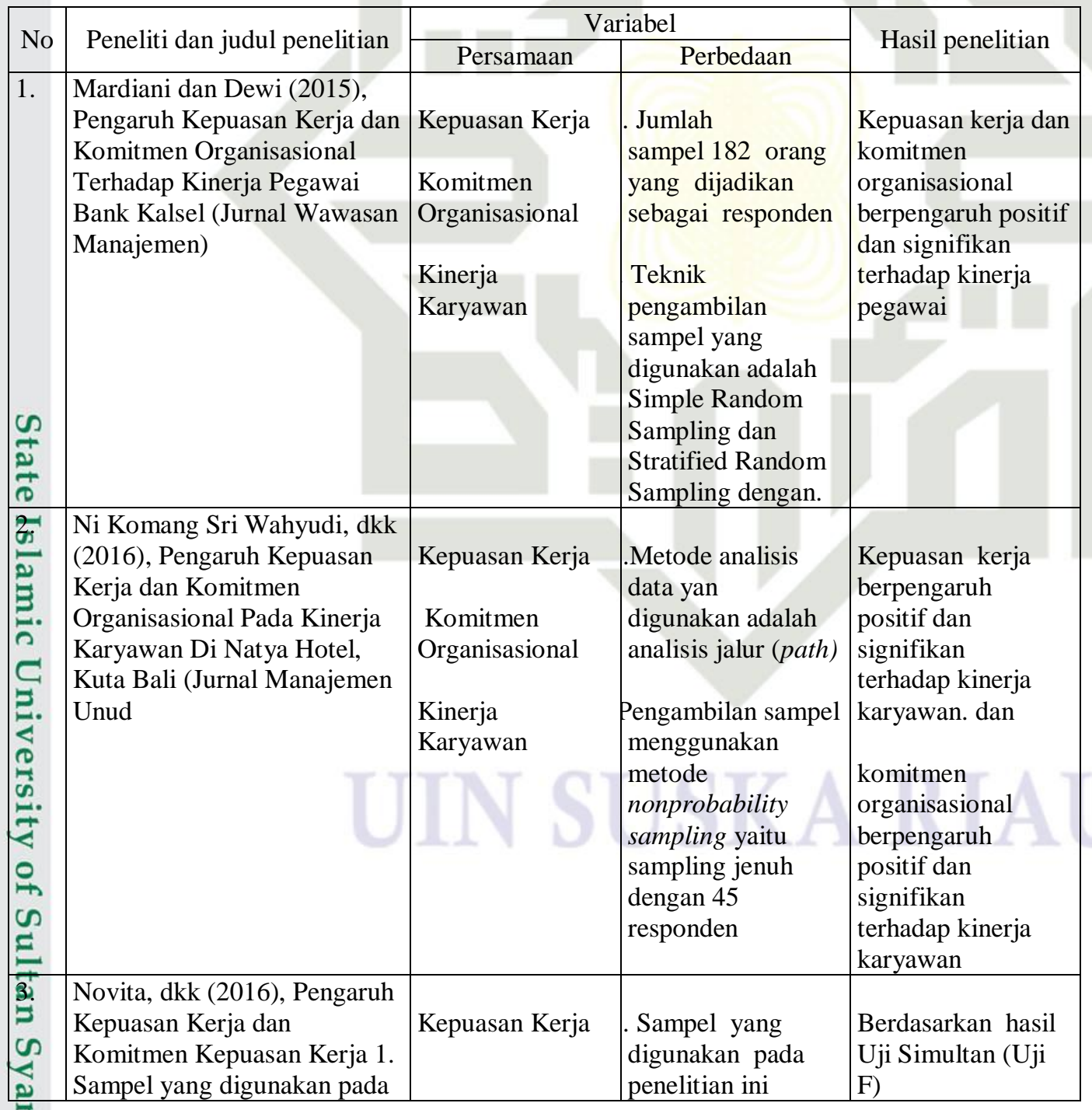


\begin{tabular}{|l|r} 
Peneliti dan judul penelitian & Variabe \\
\cline { 2 - 2 } &
\end{tabular}

penelitian ini Berdasarkan

$\rightarrow$ hasil Uji Simultan (Uji F)

\% Organisasional

Terhadap

Kinerja Karyawan (Studi pada Komitmen

PT.

Telekomunikasi Organisasional

Indonesia, Tbk Witel Jatim

Selatan, Malang) (Jurnal Kinerja

Administrasi Bisnis)

Karyawan

74. Ranty

\begin{tabular}{c|l} 
sapitri & Komitnen \\
mitmen & organisasi
\end{tabular}

(2016),penagaruh komitmen
organisasi terhadap kinerja

karyawan perusahaan listrik Kinerja karyawan

ᄃ negara area pekanbaru

\begin{tabular}{|l|r|}
\hline & Pebanyak \\
karyawa
\end{tabular}

sampel yang

digunakan dalam

penelitian ini

adalah

proportional

random sampling

Jumlah sampel Komitmen

76 orang yang organisasin

dijadikan sebagai memiliki pengaruh

responden

positif

signifikan terhadap

metode yang kinerja karyawan

digunakan

penelitian

mengunakan teknik

sensus

5. Iwan kurnia wijaya (2018), Kepuasan kerja pengaruh kepuasan kerja

terhadap kinerja karyawan cv Kinerja karyawan

jumlah sampel 73

orang yang

bukit sanomas

responden

lam

ini

kepuasan

komitmen

organisasional

berpengaruh

signifikan terhadap

variabel kinerja

bukit sanomas

metode yang

digunakan dalam

penelitian ini

mengunakan

\subsection{Kerangka Pemikiran}

Kerangka pemikiran merupakan model konseptual tentang bagaimana teori

berhubungan dengan berbagai faktor yang telah di identifikasi sebagai masalah ¿

penting.

(⿻).

Robbins \& Judge (2012:99) menerangkan bahwa seseorang dengan $\stackrel{\circ}{\circ}$

tingkat kepuasan kerja yang tinggi memiliki perasaan-perasaan positif tentang E

pekerjaan tersebut, sementara seseorang yang tidak puas memiliki perasaan-

perasaan yang negative tentang pekerjaannya.

일 


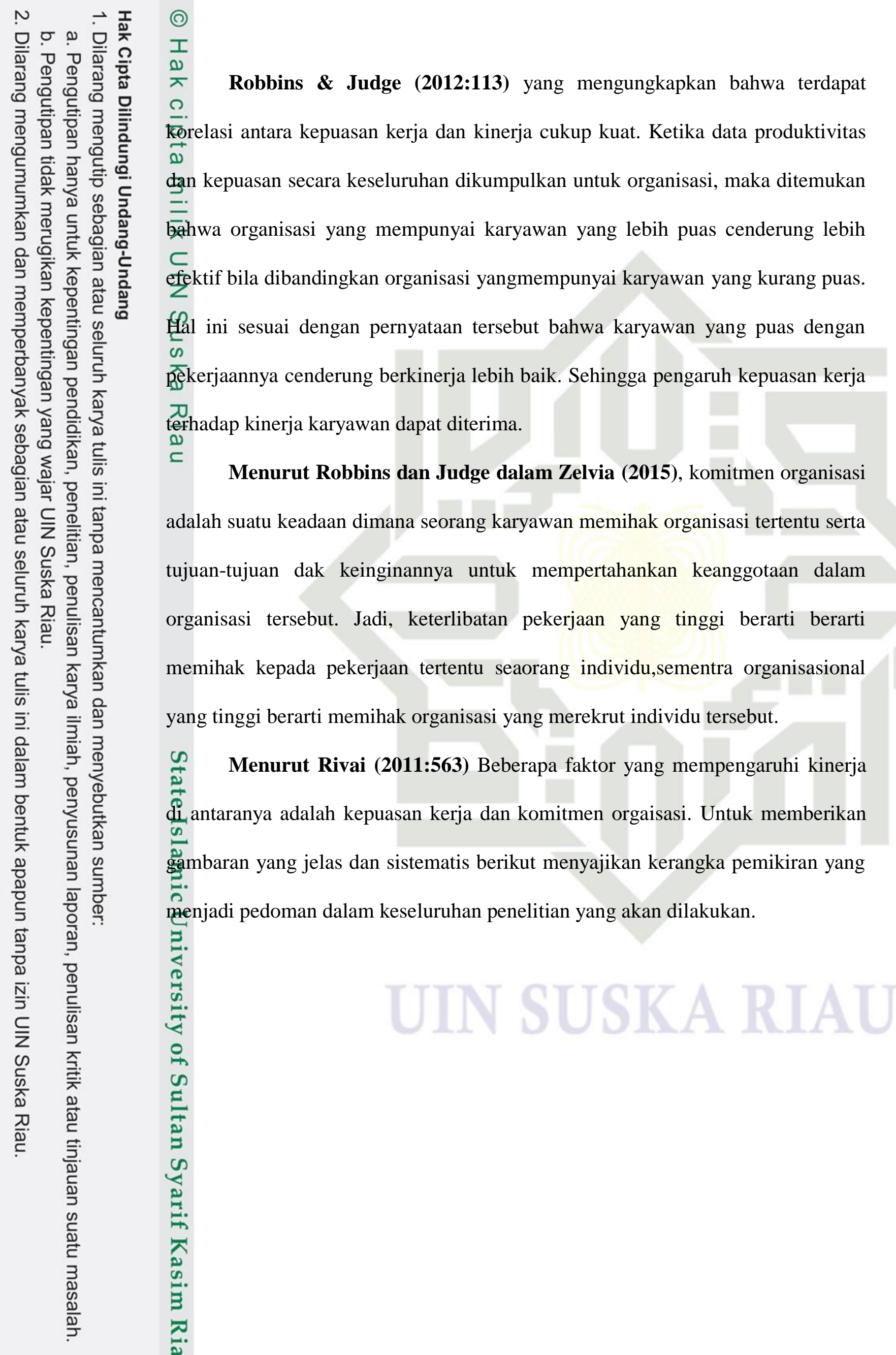




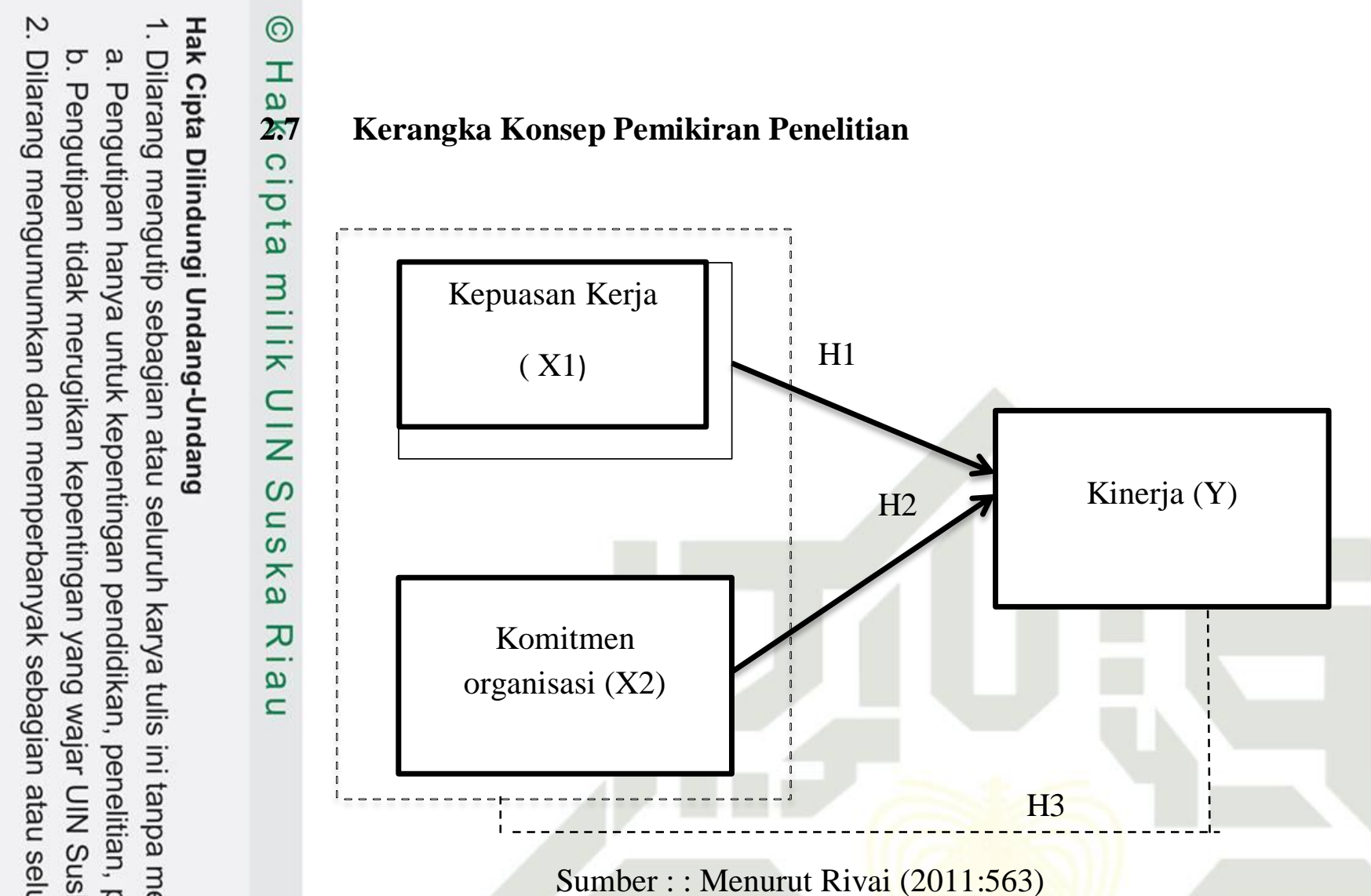

\section{Gambar 2.1 : Model Kerangka Pemikiran Tentang Pengaruh Kepuasan Kerja (X1) dan Komitmen organisasi (X2) Terhadap Kinerja (Y)}

Keterangan:

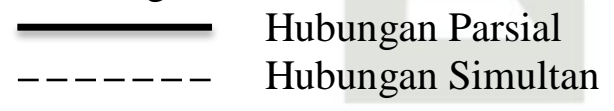

\section{Hipotesis}

Hipotesis merupakan jawaban sementara terhadap rumusan masalah penelitian. Hipotesis juga dapat dinyatakan sebagai jawaban teoritis terhadap क rumusan masalah penelitian, belum jawaban yang empirik Sugiyono,(2014:93). 4

Berdasarkan identifikasi masalah dan kerangka penelitian yang telah di uraikan, ( maka dapat dirumuskan hipotesis dalam penelitian ini sebagai berikut: 


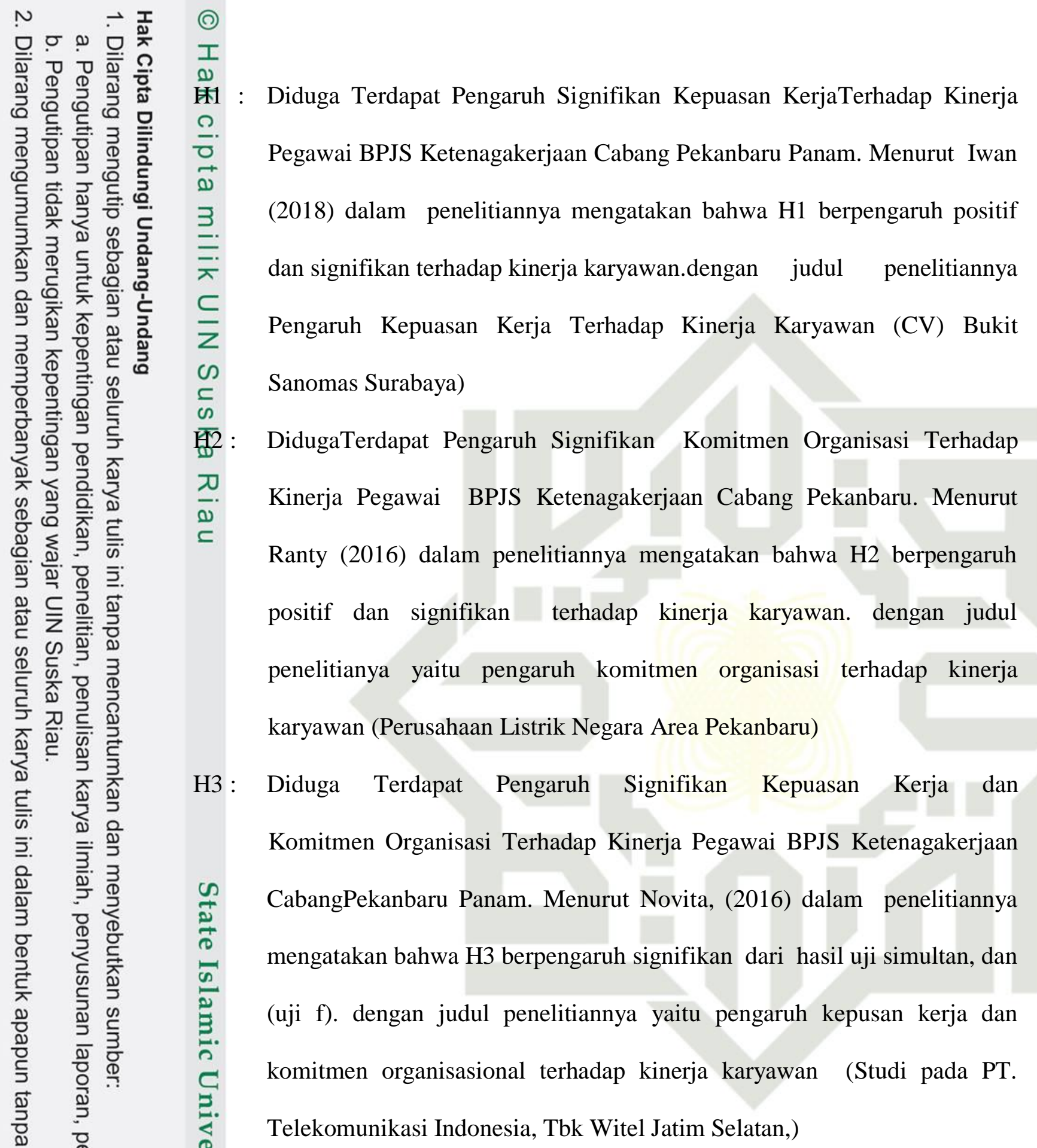

\section{Definisi Operasional}

Adapun devinisi operational dalam penelitian ini adalah variabel bebas merupakan variabel yang tidak dipengaruhi variabel lain variabel yang 
(1)

öganisasi (X2) sedangkan variabel terikat Kinerja pegawai (Y) merupakan ?.

₹ăriabel yang dipengaruhi v ariabel lain dibawah ini (1)

\section{Tabel 2.2: Definisi dan Konsep Operasional Variabel}

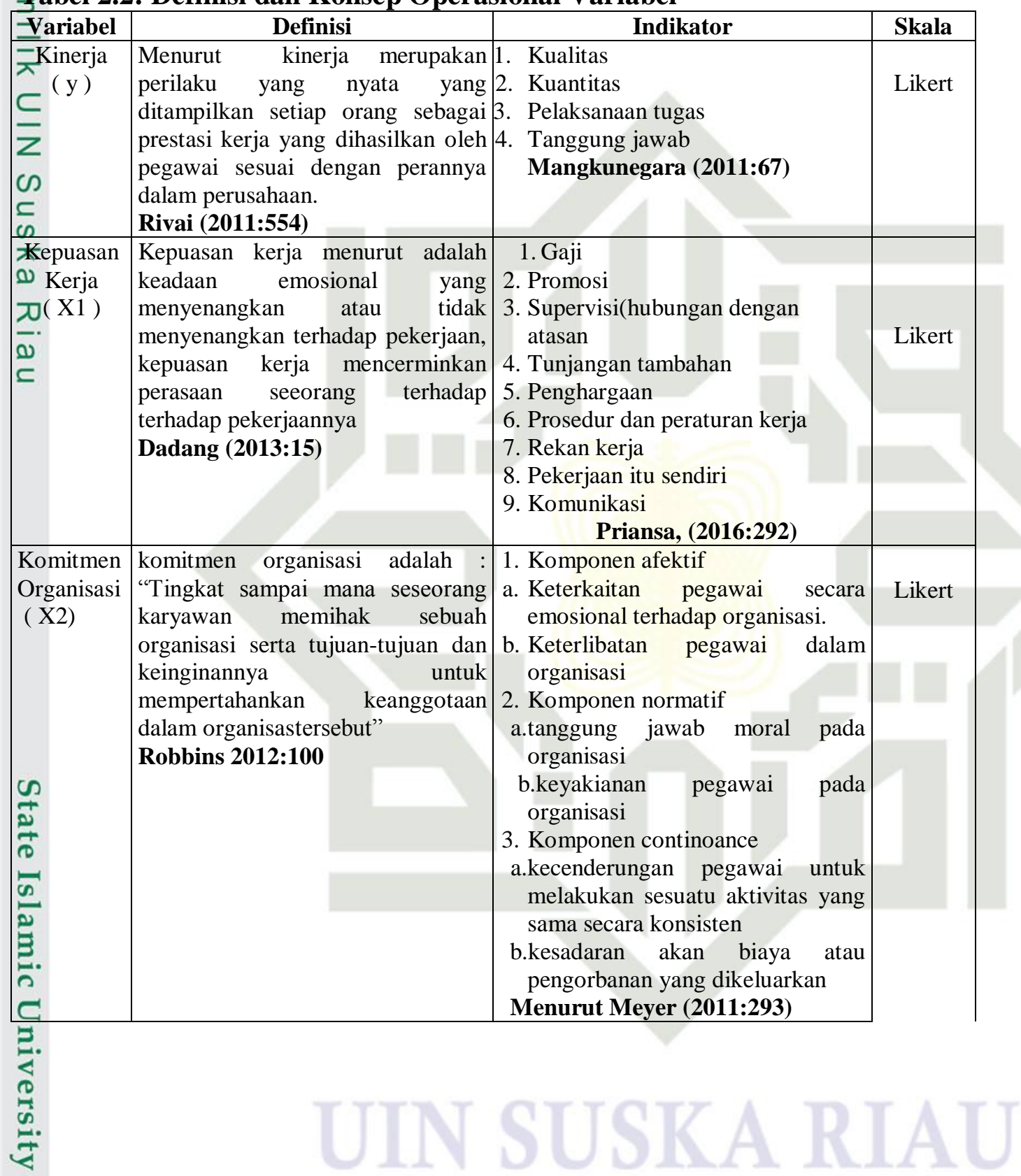



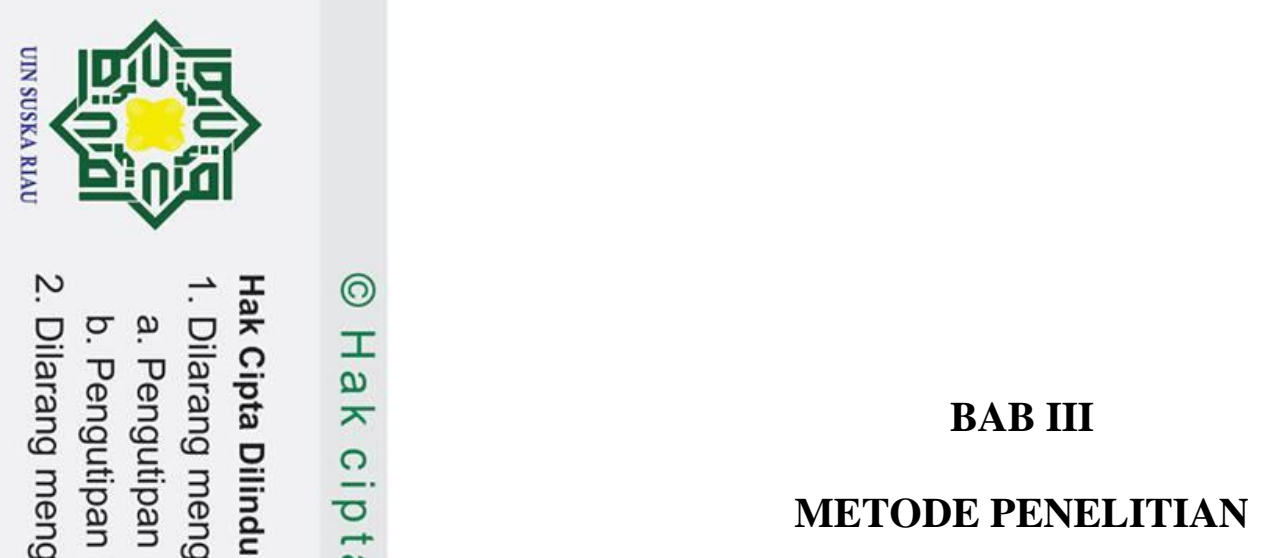

3.1 Lokasi dan Waktu Penelitian

Lokasi penelitian dilaksanakan di BPJS Ketenagakerjaan cabang Pekanbaru panam jalan HR. Soebrantas,no 8 a - b Kota Pekanbaru, Riau dan (

WWaktu penelitihan ini direncanakan selama 3 bulan terhitung sejak proposal त

penelitihan ini diseminarkan dan dilanjutkan dengan penulisan skripsi sampai đ̣̊ngan ujian sarjana.

\subsection{Populasi dan Sample Penelitian}

\subsubsection{Populasi}

Populasi adalah wilayah generalisasi yang terdiri dari objek atau subjek yang memiliki kuantitas dan karasteristik tertentu yang di tetapkan oleh peneliti untuk di pelajari dan kemudian ditarik kesimpulannya Supryanto dan Maharan, (2013: 35). Adapun populasi pada penelitian ini adalah seluruh Pegawai BPJS $\stackrel{2}{2}$

Ketenagakerjaan Cabang Pekanbaru Panam Sebanyak 25 Pegawai.

\subsubsection{Sampel}

Sebagaimana di kemukan oleh Sugiyono (2016 : 81) sampel adalah bagian

dari jumlah karastristik yang dimiiki oleh populasi tersebut. Menurut sugiyono ( 2016: 85) Teknik penarikan sampel dilakukan dengan teknik sampling jenuh

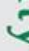
adalah apabila kurang dari 100 orang maka lebih baik diambil semua. Hal ini sêring dilakukan bila jumlah populasi relatif kecil. Adapun sampel yang di F tễ tapkan dalam penelitihan ini adalah seluru pegawai Bpjs Ketenagakerjaan o șégbanyak 25 orang Pegawai. 
(2)

I

3.3

$\underline{-1}$

ब)

31

1. Data primer

Menurut Etta Mamang, Sopiah, (2010:171). data primer adalah data yang penulis peroleh secara langsung dari identitas respoden dan juga hasil dari jawaban terhadap kuesioner tentang pengaruh kepuasan kerja dan komitmen organisasi terhadap kinerja BPJS ketenagakerjaan Cabang Pekanbaru Panam.

b. Data Sekunder

Data sekunder yaitu data yang diperoleh peneliti secara tidak langsung atau melalui media perantara (diperoleh dan dicatat oleh pihak lain), umumnya berupa bukti, catatan ataupun laporan historis yang tersusun dalam arsip Etta Mamang, Sopiah, (2010:288) Data ini biasanya di peroleh melalui dokumen-dokumen, buku-buku, laporan-laporan atau hasil ilmiah lainnya yang ada kaitannya dengan penelitian.

\section{Teknik Pengumpulan Data}

Alat yang digunakan untung menjaring data tentang kepuasan kerja , komitmen organisasi, dan Kinerja Pegawai adalah angket (kusioner):

1. Kusioner

Menurut Supriyanto dan Machfudz (2010: 199) Kusioner merupakan teknik pengumpulan data yang dilakukan dengan cara memberikan pertanyaan atau pernyataan tertulis kepada responden untuk dijawabnya. Adapun angket yang disusun sesuai dengan indikator 


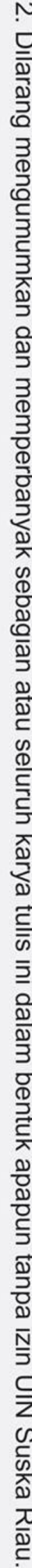

(9)

I

a)

ㄱ.

7.

क)

马

3,5

penelitian yaitu tentang pengaruh kepuasan kerja dan komitmen organisasi terhadap kinerja pegawai Bpjs Ketenagakerjaan Cabang Pekanbaru Panam

\section{Skala Pengukuran}

Adapun skala pengukuran dalam penelitian ini menggunakan skala likert.

MPenurut Suliyanto (2011: 10) skla likert digunakan untuk mengukur tanggapan os

atău respon seseorang tentang obyek sosial. Jawaban setiap instrumen yang a)

mengguanakan skala likert mempunyai nilai yang sangat positif dan yang sangat (1)

rfegatif. Apabilah item positif, maka angka terbesar diletakkan pada "sangat

setuju". Namun jika item negatif, angka terbesar di letak kan pada "sangat tidak

setuju". Skala Likert selalau ganjil dan ada selalu pilihan "netral". Maka dalam penelitihan ini hanya digunakan lima kategori diantaranya:

1. Sangat Setuju (SS) = dengan skor 5

2. Setuju ( S ) = dengan skor 4

क

3. Netral $(\mathrm{N})=$ dengan skor 3

4. Kurang Setuju ( KS) = dengan skor 2

5. Tidak setuju ( TS ) = dengan skor 1

3 Uji Kualitas Data

承.

Uji kualitas instrumen bertujuan mengetahui konsistensi dan akurasi data

yang dikumpulkan.Cara pengujian dilakukan dengan Uji Validitas dan Uji

Ř̉eliabilitas dari data yang telah didapat memalui kuesioner responden. Ada dua

sfarat penting yang berlaku pada sebuah kuesioner, yaitu keharusan kuesioner $\rightleftharpoons$

ب̣̂ำtuk Valid dan Reliabel. Suatu kuesioner dikatakan valid kalau pertanyaan pada क

ş̆atu kuesioner mampu mengungkapkan sesuatu yang akan diukur oleh kuesioner 


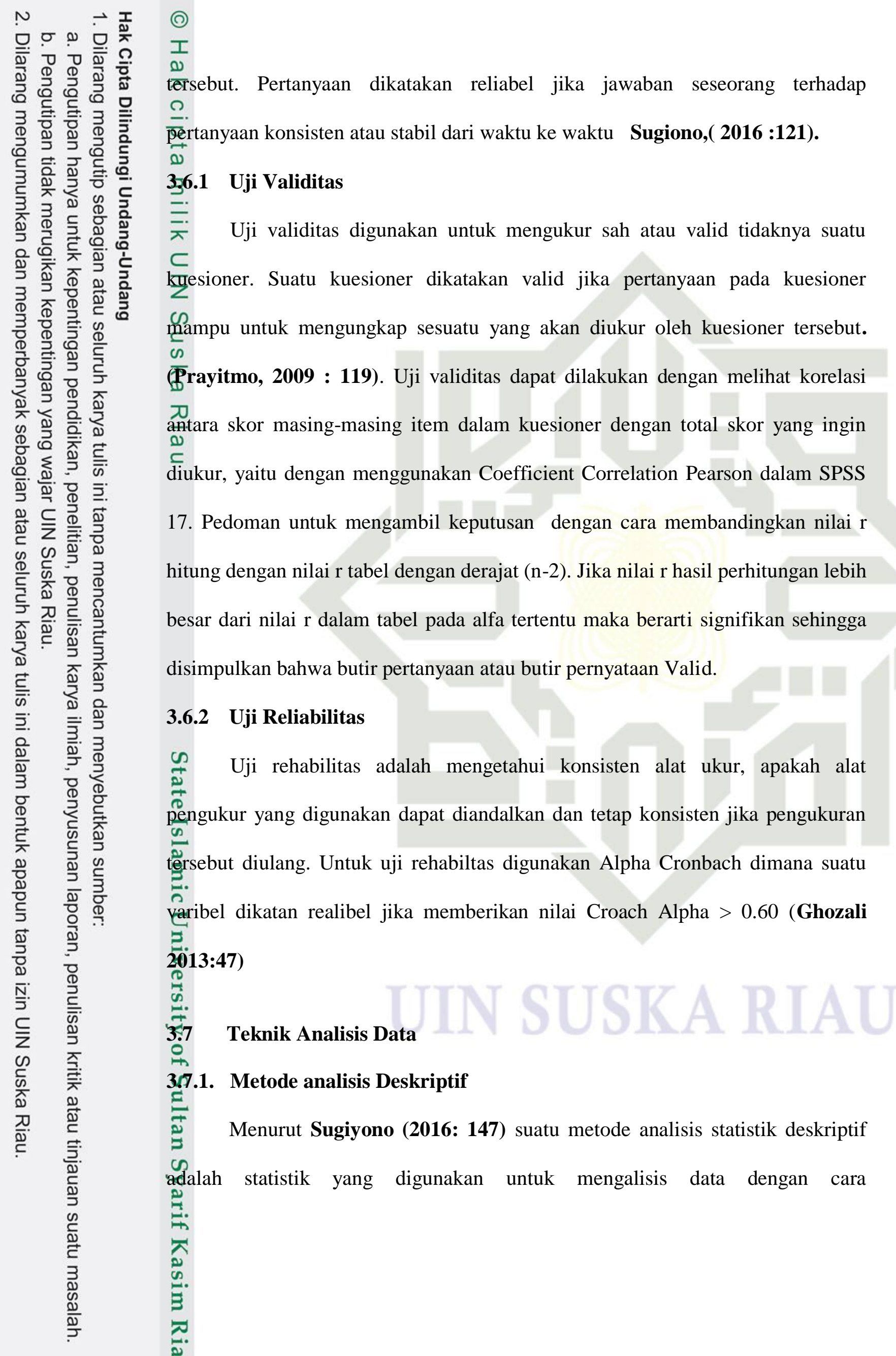


m̄endeskripsikan dan atau menggambarkan data yang telah terkumpul ?.

sebagaimana adanya tanpa bermaksud membuat kesimpulan yang berlaku untuk a) unnum dan generalisasi.

\subsubsection{Metode Analisis Kuantitatif}

$\bar{\subset} \quad$ Menurut Sugiono (2016: 8) Metode analisis kuantitatif adalah metode pénelitihan yang berlandaskan pada filsafat positivisme, digunakankan untuk (s) గ্⿵冂⿰亻丨乚

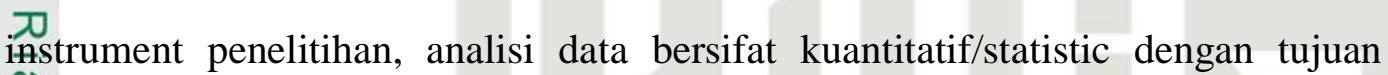
ล)

$\subset$ menguji hipotesa yang telah ditetapkan. Dalam penelitian ini model dan teknik analisa data menggunkan pendekatan analisis regresi linear berganda. Sebelum dilakukan analisi regresi berganda terlebih dahulu dialakukan uji kualitas instrumen penelitihan dan uji asumsi klasik yang diolah menggunkan program SPSS versi 22 for windows

\subsection{Uji Asumsi Klasik}

i Menurut Suliyanto (2011 : 69) Uji asumsi klasik bertujuan untuk memberikan kepastian bahwa persamaan regrasi yang didapatkan memiliki 2 kettetapan dalam esttimasi, tidak bias dan konsisten

\subsubsection{Uji Normalitas}

Uji Normalitas Data adalah langkah awal yang harus dilakukan untuk 点.

sêtiap analisis multivariate khususnya jika tujuannya adalah inferensi. Tujuannya $\circ$ adfalah untuk menguji apakah dalam model regresi, variabel dependen dengan $\Xi$ katriable independen mempunyai distribusi normal atau tidak. Model regresi yang $\exists$ baik adalah distribusi data normal atau mendekati normal. 


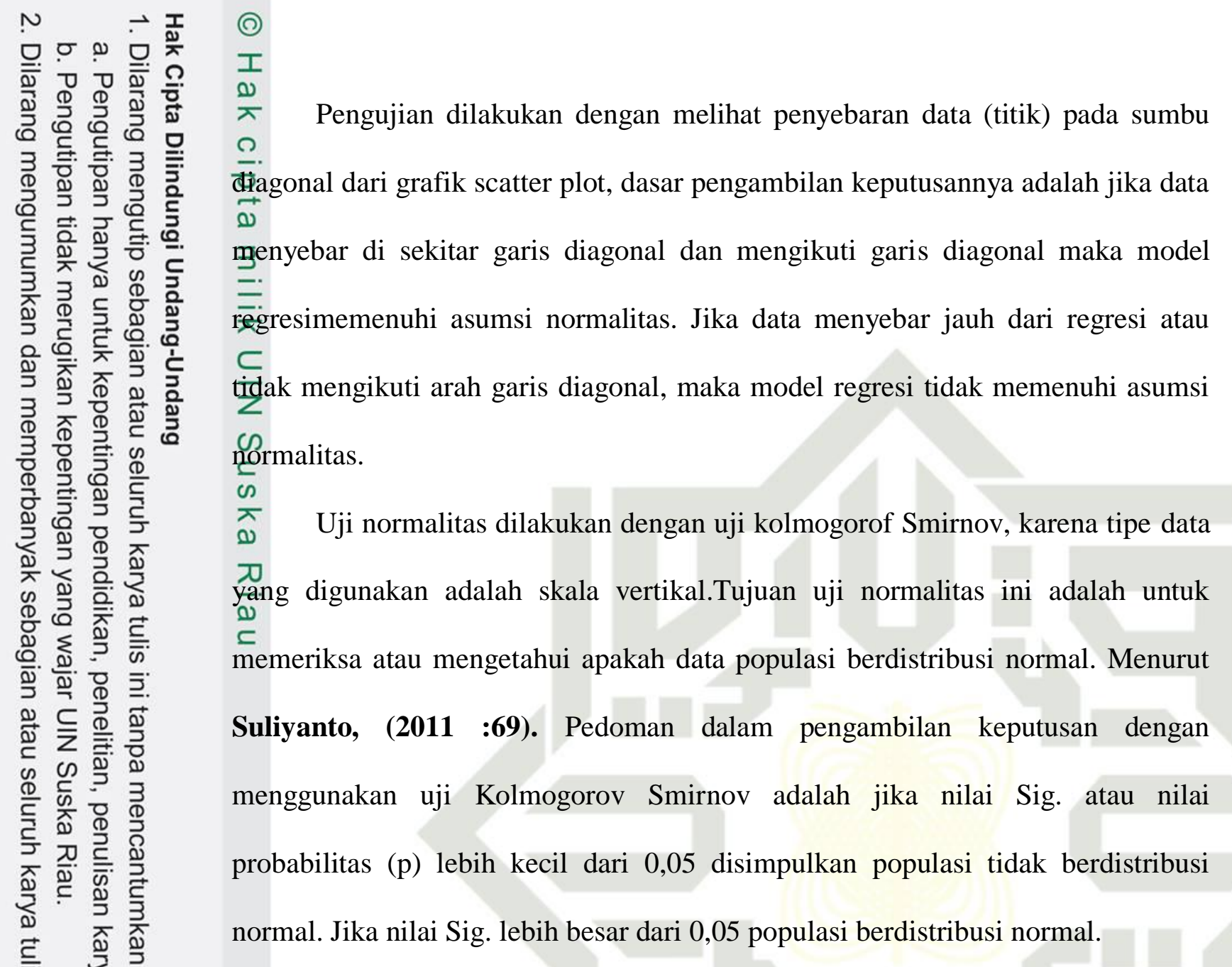

\subsubsection{Uji Multikolinieritas}

( Uji ini Bertujuan Untuk menguji apakah dalam rekgresi ditemukan adanya korelasi antar variabel bebas atau tidak, model yang baik seharusnya tidak terjadi क

korelasi yang tinggi antara variabel bebas. Untuk mendeteksi ada tidaknya :

multikolneritas dalam model regresi dapat dilihat dari nilai toleransi dan nilai 当.

Kariance Inflation Factor ( VIF). Uji multikolinieritas dapat dilakukan dengan () melihat nilai VIF (Variance Inflation Factor) dari masing-masing variabel ¿

bebasnya terhadap variabel terikatnya.Jika nilai VIF (Variance Inflation Factor) w

tïlak lebih dari 10. Maka model regresi dinyatakan tidak terdapat gejala

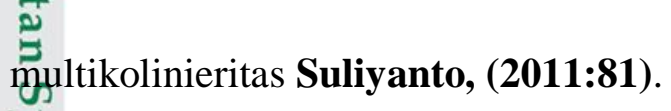




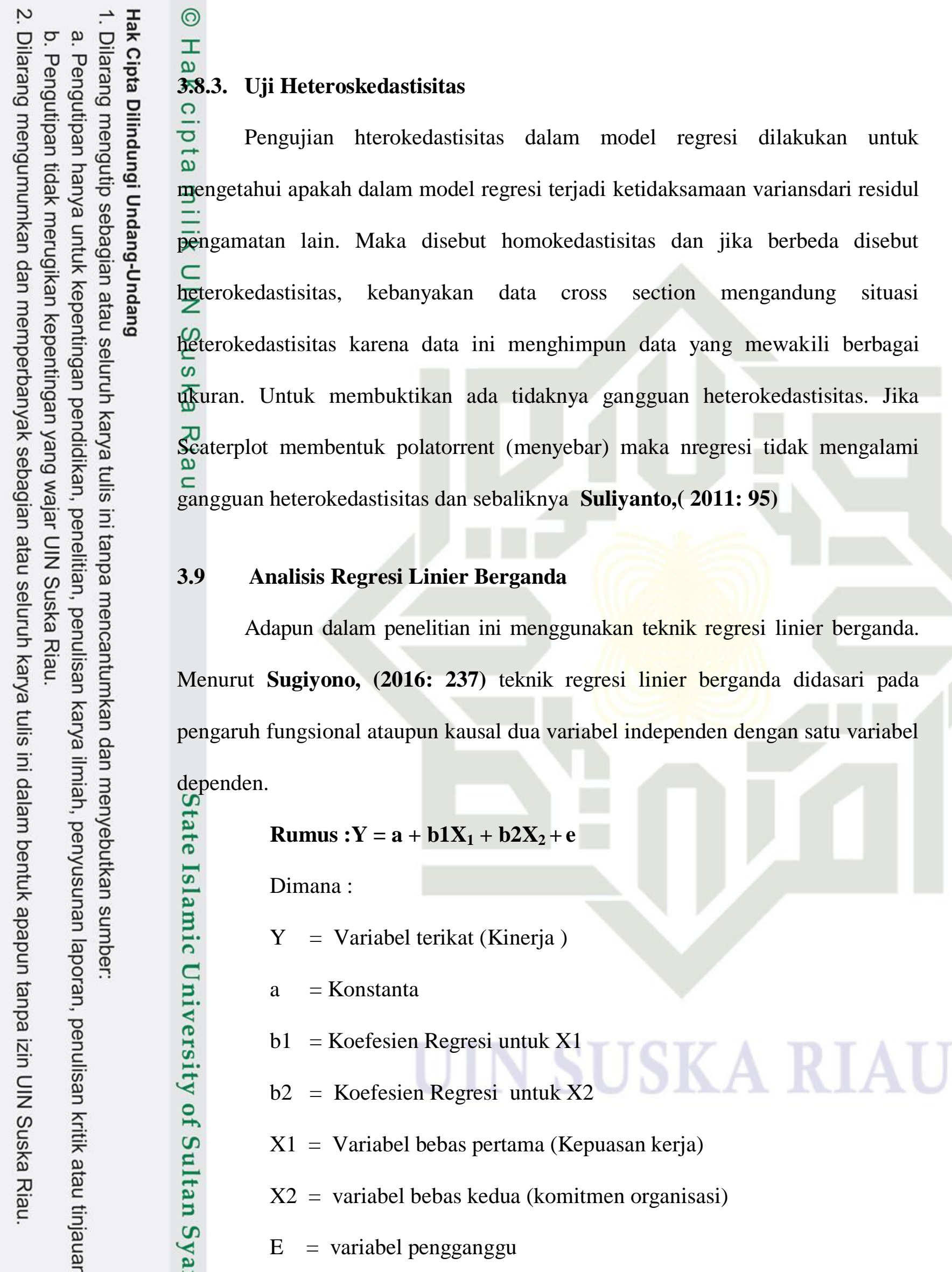




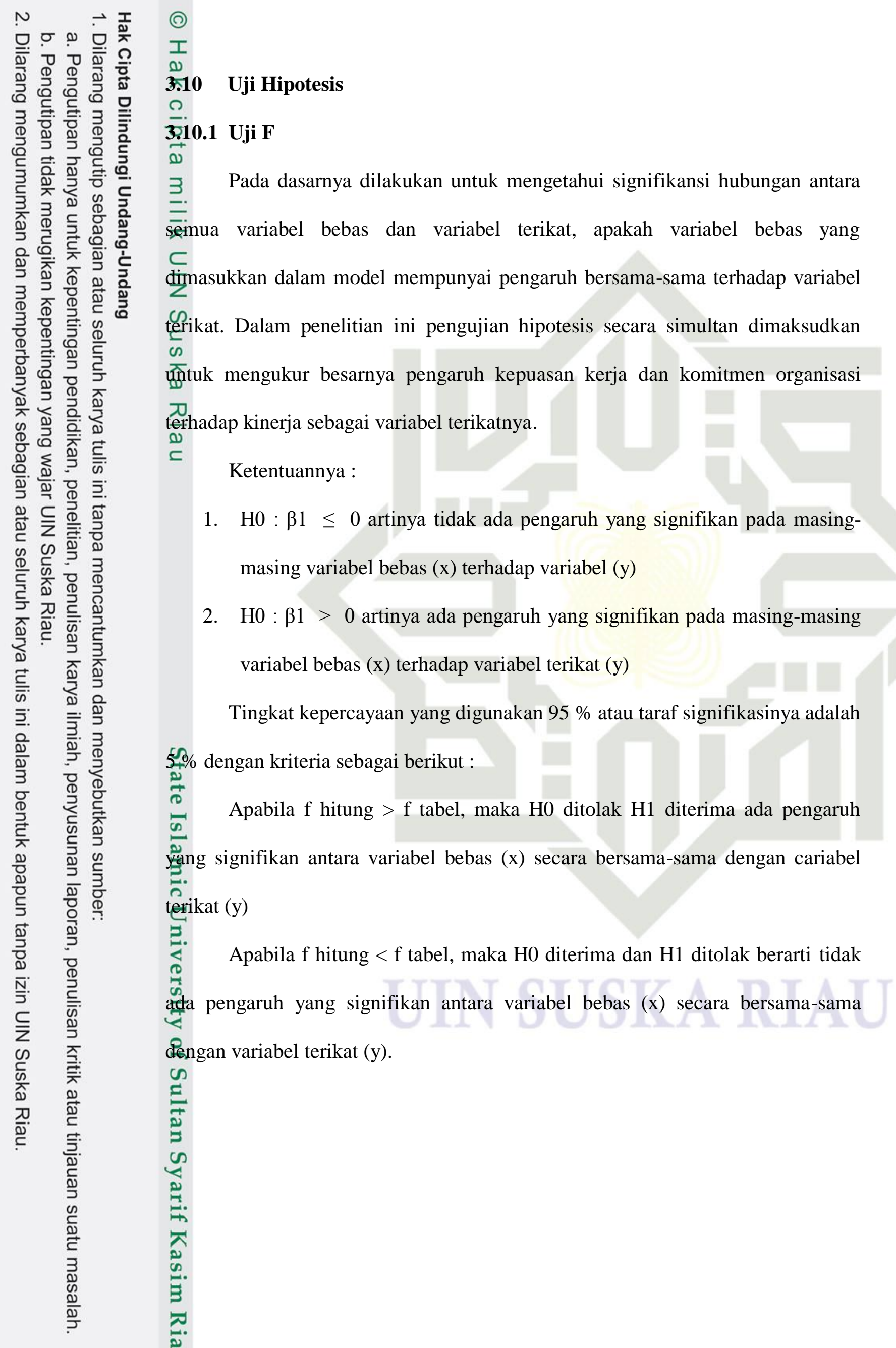




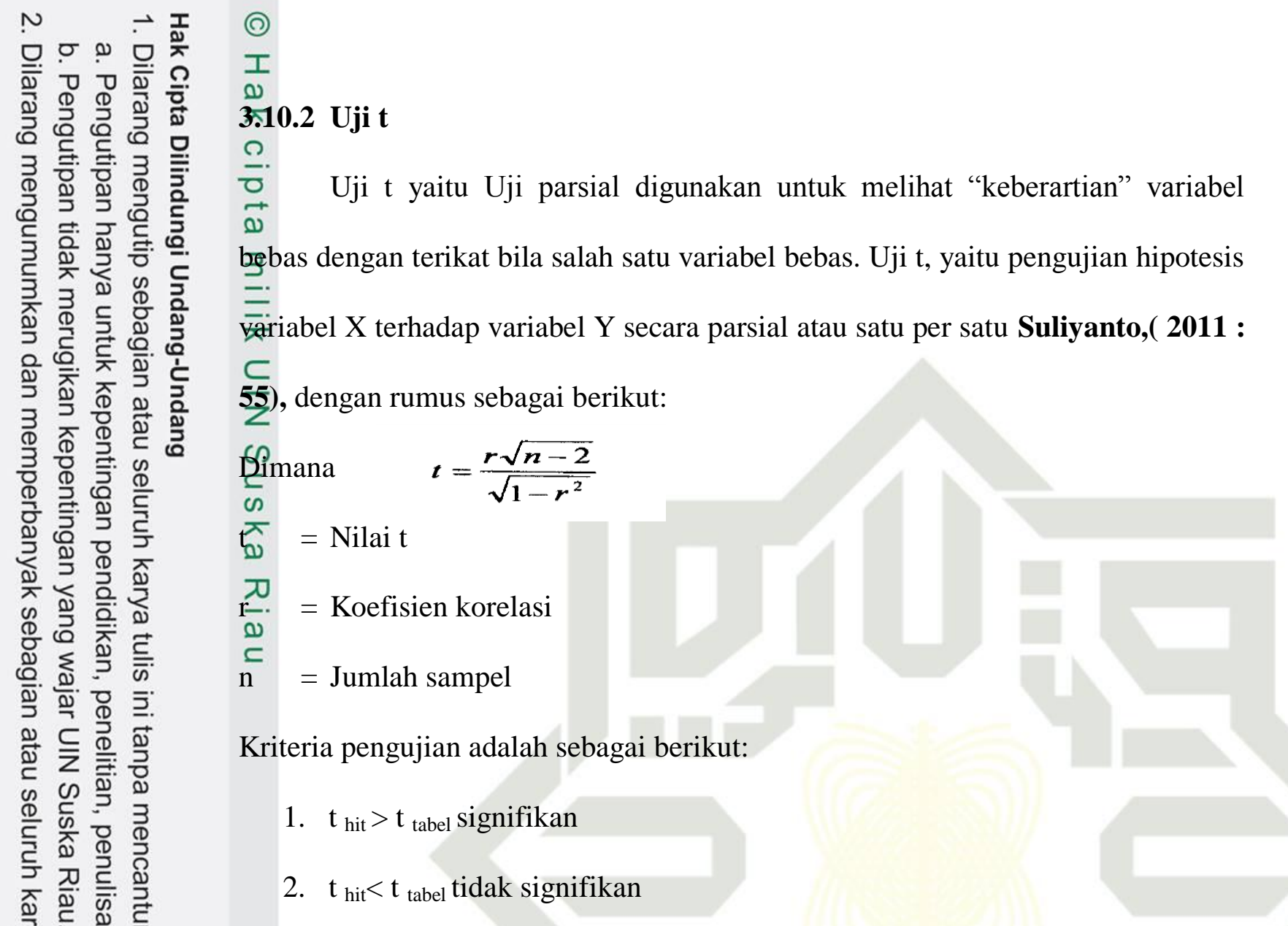

\subsubsection{Kofisien Determinasi}

Koefisien determinasi ( R2) pada intinya mengukur seberapa jauh

kemampuan model dalam menerangkan variasi variabel dependen. Milai koefisien $\stackrel{0}{2}$

determinasi adalah nol dan satu. Nialai ar2 yang kecil berarti kemampuan variabel क

䜦devenden dalam menjelaskan variasi variabel dependen amat terbatas. Nialai .

yang mendekati satu berarti variabel - variabel independen memberiakn hampir 己.

semua informasi yang dibutuhkan untuk memperediksi variasi variabel dependent

(

Ghozali, ( 2013 : 97) 

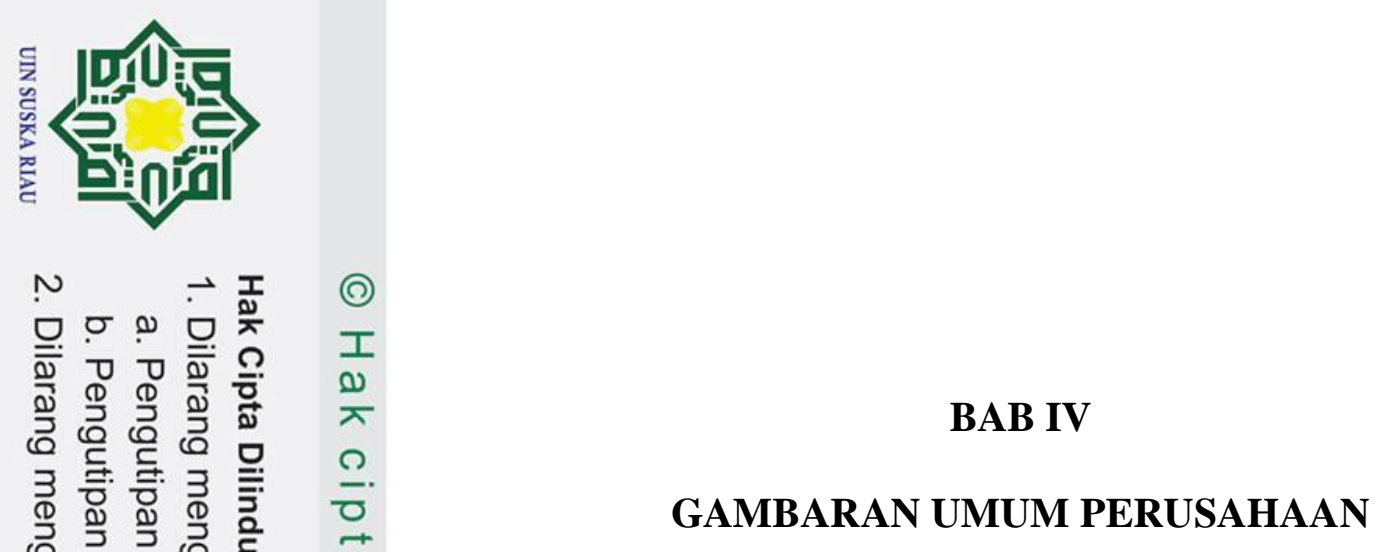

\section{Sejarah Perusahaan}

BPJS Ketenagakerjaan adalah (Badan Penyelenggara Jaminan Sosial Ketenagakerjaan) merupakan program publik yang memberikan perlindungan ( bagi tenaga kerja untuk mengatasi risiko sosial ekonomi tertentu dan $\pi$ penyelenggaraan nya menggunakan mekanisme asuransi sosia sebagai lembaga Ňegara yang bergerak dalam bidang asuransi sosial BPJS Ketenagakerjaan yang dahulu bernama PT Jamsostek (Persero) merupakan pelaksana undang-undang jaminan sosial tenaga kerja. BPJS Ketenagakerjaan sebelumnya bernama Jamsostek (jaminan sosial tenaga kerja), yang dikelola oleh PT. Jamsostek (Persero), namun sesuai UU No. 24 Tahun 2011 tentang BPJS, PT. Jamsostek berubah menjadi BPJS Ketenagakerjaan sejak tanggal 1 Januari 2014.

$\stackrel{\infty}{\text { Keteta }}$ BPJS Ketenagakerjaan (Badan Penyelenggaraan Jaminan Sosial R्Fetanagakerjaan) merupakan program publik yang memberikan perlindungan bagi tenaga kerja untuk mengatasi risiko sosial ekonomi 光 tertentu dan penyelenggaraannya menggunakan mekanisme asuransi sosial. Sebagai Badan Usaha Milik Negara yang bergerak dalam bidang asuransi sosial BPJS Ketenagakerjaan yang dahulu bernama PT Jamsostek asuransi sosial BPJS Ketenagakerjaan yang dahulu bernama PT Jamsostek (P्Persero) merupakan pelaksana undang-undang jaminan sosial tenaga kerja. $\stackrel{0}{\rightarrow}$

BPJS Ketenagakerjaan sebelumnya bernama Jamsostek (jaminan sosial

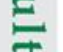

tể̇naga kerja), yang dikelola oleh PT. Jamsostek (Persero), namun sesuai UU No. 24 Tahun 2011 tentang BPJS, PT. Jamsostek berubah menjadi BPJS $\stackrel{2}{2}$ 


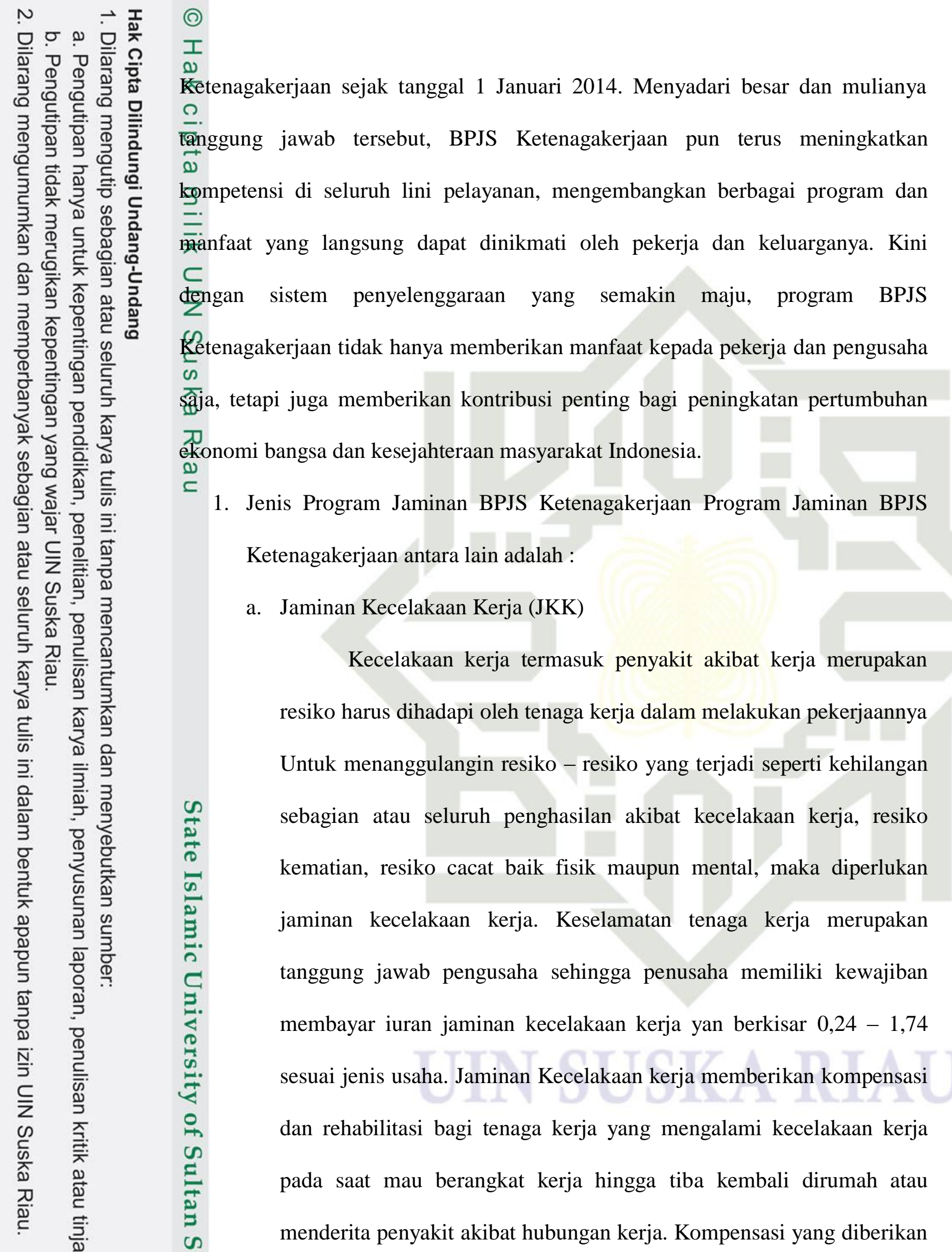


kepada tenaga kerja yang mengalami kecelakaan kerja berupa penggantian biaya yang dikeluarkan pengusaha yaitu transport, upah sementara tidak mampu bekerja (STMB) dan perawatan, ganti rugi atas turunan/hilangnya kemampuan bekerja/berpenghasilan yaitu santunan cacat dan santunan kematian.

b. Jaminan kematian (JKM)

Jaminan Kematian diperuntukan bagi ahli waris dari peserta program BPJS Ketenagakerjaan yang meninggal bukan karena akibat kecelakaan kerja, yang perlindungannya adalah saat tenaga kerja aktif bekerja sampai dengan 6 (enam) bulan setelah tenaga kerja berhenti bekerja.Jaminan kematian diperlukan sebagai upaya meringankan beban keluarga baik dalam bentuk pemakaman maupun santunan berupa uang. Pengusaha wajib menanggung iuran program jaminan kematian sebesar $0,3 \%$ dengan jaminan kematian yang diberikan adalah Rp.24.000.000 terdiri atas : Santunan sekaligus Rp. 16.200.000,00(enam belas jutadua ratus ribu rupiah), Santunan berkala 24 x Rp. $200.000,00=$ Rp. 4.800.000,00 (empat juta delapan ratus ribu rupiah) yang dibayar sekaligus; Biaya pemakaman sebesar Rp3.000.000,00 (tiga juta rupiah). c. Jaminan Hari Tua (JHT)

Program Jaminan Hari Tua (JHT) diselenggarakan dengan sistem Tabungan Hari Tua, yang iurannya ditanggung pengusaha dan tenaga kerja setiap bulan di kredit pada rekening tenaga kerja secara individual dan mendapat tambahan hasil pengembangan setiap tahun. Dana jaminan 
hari tua pada hakekatnya semacam dana bersama dimana peserta memberikan iuran untuk dikelola dalam investasi bersama, sehingga hasil pengembangannya dibagikan kepada peserta, karena itu peserta Jaminan Hari Tua juga diberikan surplus hasil usaha BPJS Ketenagakerjaan. Besarnya iuran yang diberikan yaitu $5,7 \%$ terdiri dari $3,7 \%$ dari pemberi kerja dan $2 \%$ dari pesertanya itu sendiri. Jaminan Hari Tua akan dikembalikan/dibayarkan sebesar iuran yang terkumpul ditambah dengan pengembangan dan surplus hasil usaha, apabila tenaga kerja:

1) Mencapai umur 56 tahun, atau mengalami cacat total sehinga tida dapat bekerja kembali atau meninggal dunia.

2) Mengalami PHK setelah dan sedang tidak aktif bekerja dimanapun

3) Bekerja karena mengundurkan diri,

Peserta yang meninggalkan wilayah Indonesia untuk selamanya. Manfaat lain dari keikutsertaan dalam jaminan sosial adalah sebelum mencapai usia 56 tahun dapat diambil sebagian jika mencapai kepesertaan 10 tahun dengan ketentuan, diambil max $10 \%$ dari total saldo sebagai persiapan usia pensiun dan diambil max $30 \%$ dari total saldo untuk uang perumahan.

d. Jaminan Pensiun (JP)

Jaminan pensiun adalah jaminan sosial yang bertujuan untuk mempertahankan derajat kehidupan yang layak bagi peserta dan/atau ahli warisnya dengan memberikan penghasilan setelah peserta memasuki usia pensiun, mengalami cacat total tetap, atau meninggal dunia. Manfaat dari 
jaminan pensiun adalah sejumlah uang yang dibayarkan setiap bulan kepada peserta yang memasuki usia pensiun, mengalami cacat total tetap, atau kepada ahli waris bagi peserta yang meninggal dunia. Peserta Program Jaminan Pensiun adalah pekerja yang terdaftar dan telah membayar iuran. Peserta merupakan pekerja yang bekerja pada pemberi kerja selain penyelenggara negara, yaitu peserta penerima upah yang terdiri dari, pekerja pada perusahaan dan pekerja pada orang perseorangan. Selain itu, pemberi kerja juga dapat mengikuti Program Jaminan Pensiun sesuai dengan penahapan kepesertaan. Pekerja yang didaftarkan oleh pemberi kerja mempunyai usia paling banyak 1 (satu) bulan sebelum memasuki usia pensiun. Usia pensiun untuk pertama kali ditetapkan 56 tahun dan mulai 1 Januari 2019, usia pensiun menjadi 57 tahun dan selanjutnya bertambah 1 (satu) tahun untuk setiap 3 (tiga) tahun berikutnya sampai mencapai Usia Pensiun 65 tahun. Dalam hal pemberi kerja nyata-nyata lalai tidak mendaftarkan Pekerjanya, Pekerja dapat langsung mendaftarkan dirinya kepada BPJS Ketenagakerjaan.Dalam hal peserta pindah tempat kerja,Peserta wajib memberitahukan kepesertaannya kepada Pemberi Kerja tempat kerja baru dengan menunjukkan kartu peserta BPJS Ketenagakerjaan. Selanjutnya Pemberi Kerja tempat kerja baru meneruskan kepesertaan pekerja. 
(?)

I

4.2

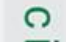

ত̄ 1 Visi

\section{Visi, Misi BPJS Ketenaga Kerjaan Cabang Pekanbaru Panam} pelayanan.

2 Misi

\section{Melalui Program Jaminan Sosial Ketenagakerjaan, BPJS}

Ketenagakerjaan berkomitmen Untuk :

a. Melindungi dan Menyejahterakan seluruh pekerja dan keluarganya

b. Meningkatkan produktivitas dan daya saing pekerja

c. Mendukung pembangunan dan kemandirian perekonomian nasional

\section{Nilai - nilai BPJS Ketenagakerjaan (ETHIKA)}

a. Iman

b. Ekselen

c. Teladan

d. Harmoni

e. Intergritas

f. Kepedulian

g. Antusiasi

\section{Struktur Organisasi}

Setiap perusahaan pada umumnya mempunyai struktur organisasi.

Penyusunan struktur organisasi merupakan langkah awal dalam memulai

pelaksanaan kegiatan organisasi, dengan kata lain penyusunan struktur organisasi 


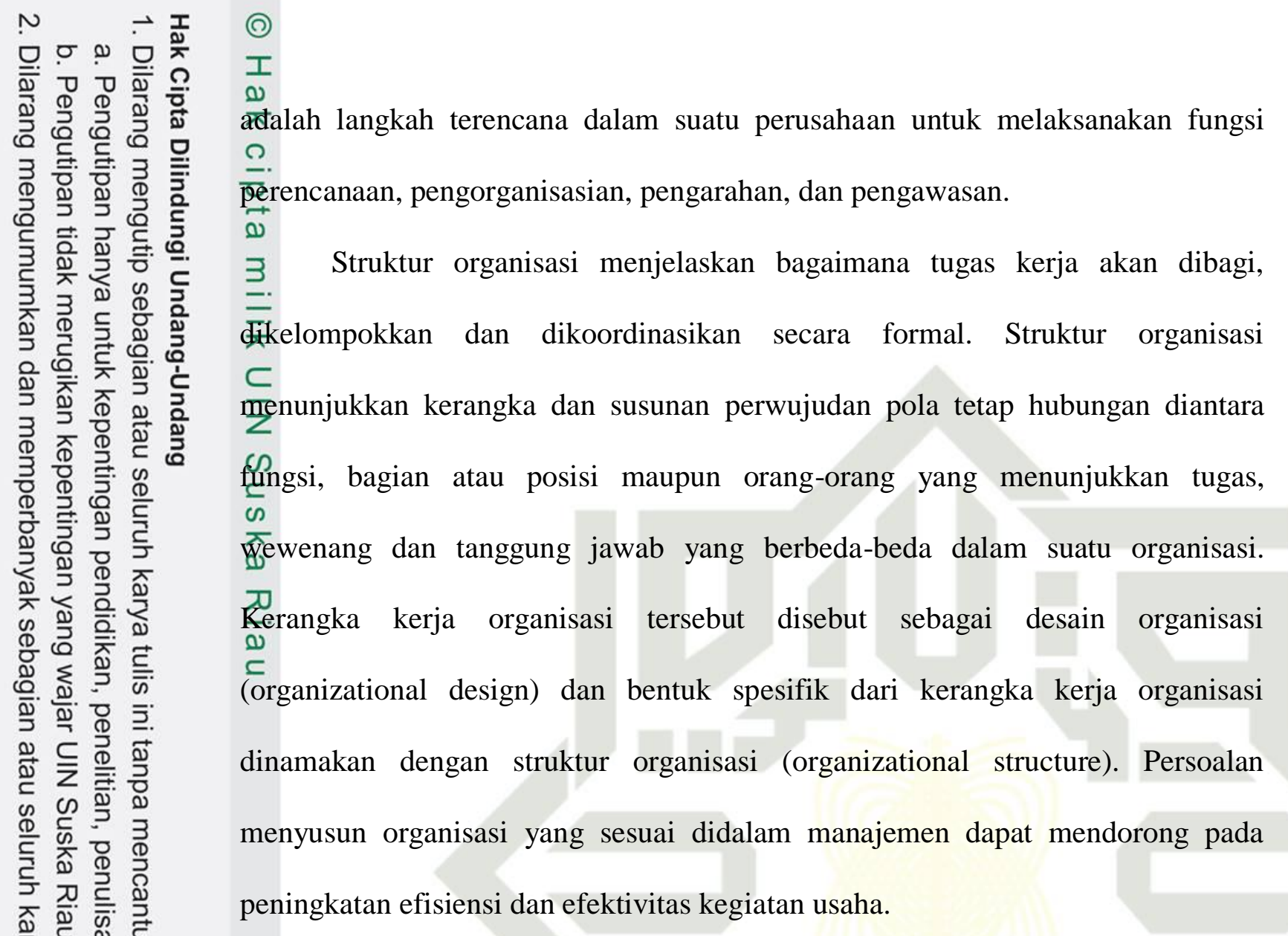




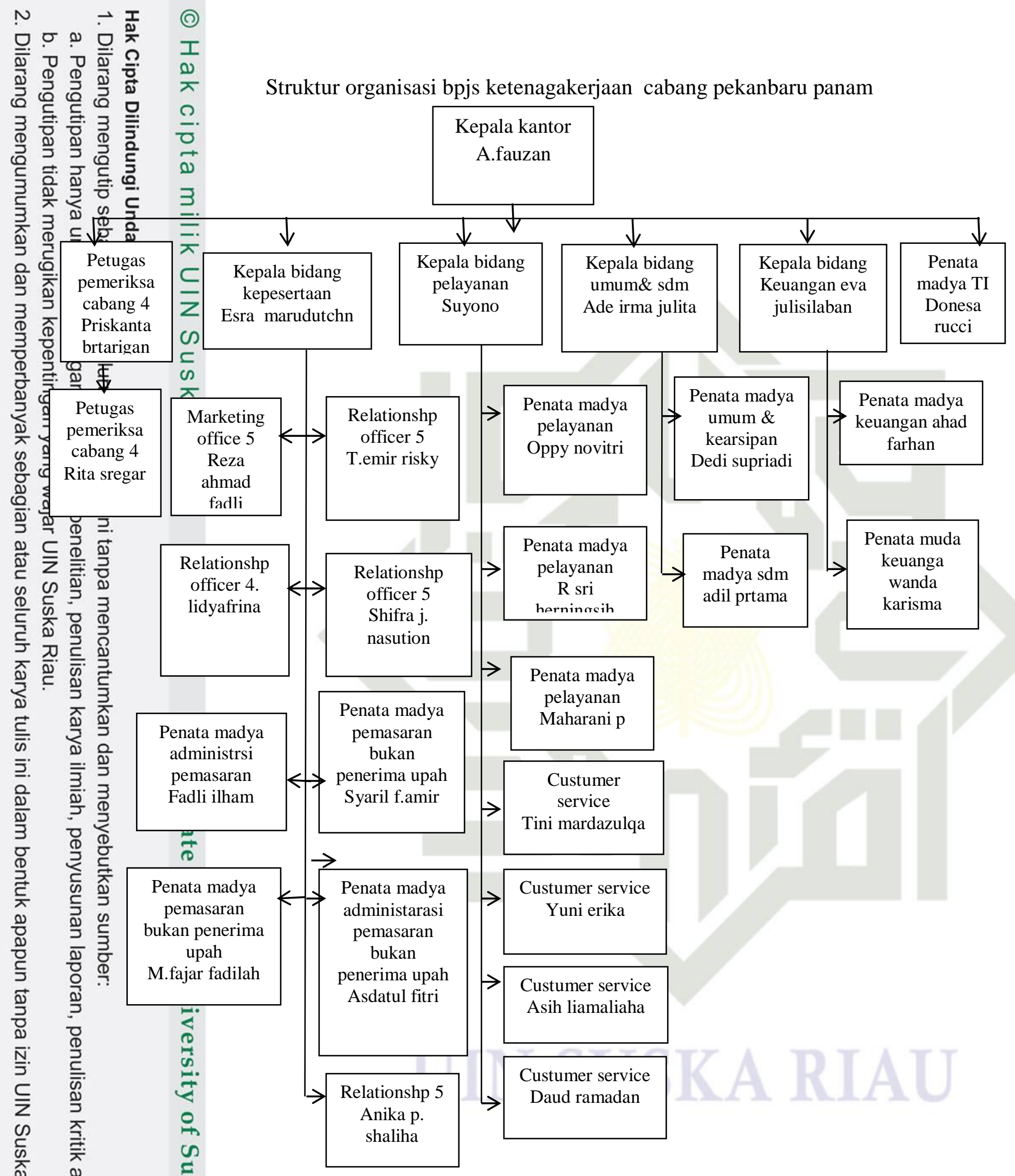




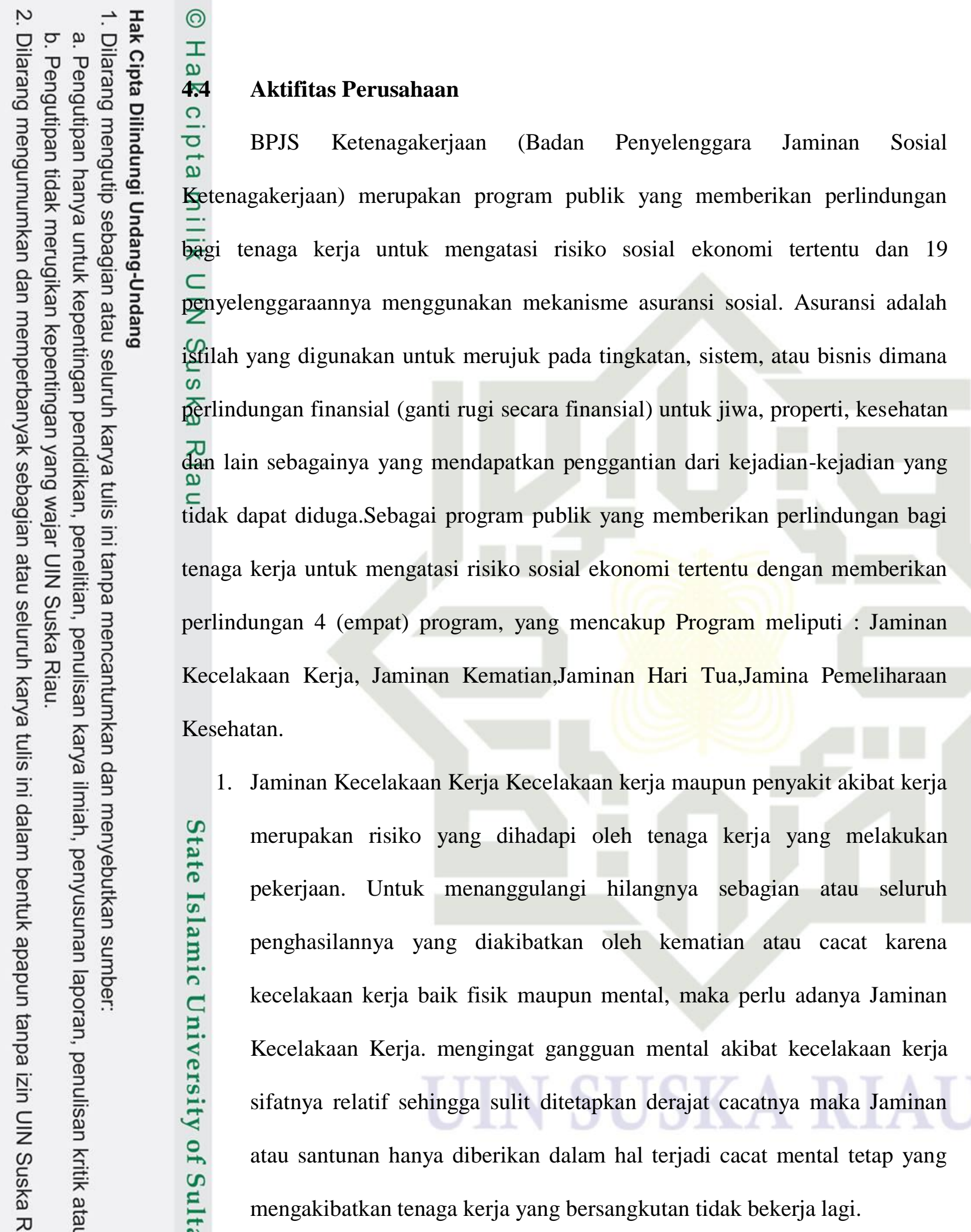




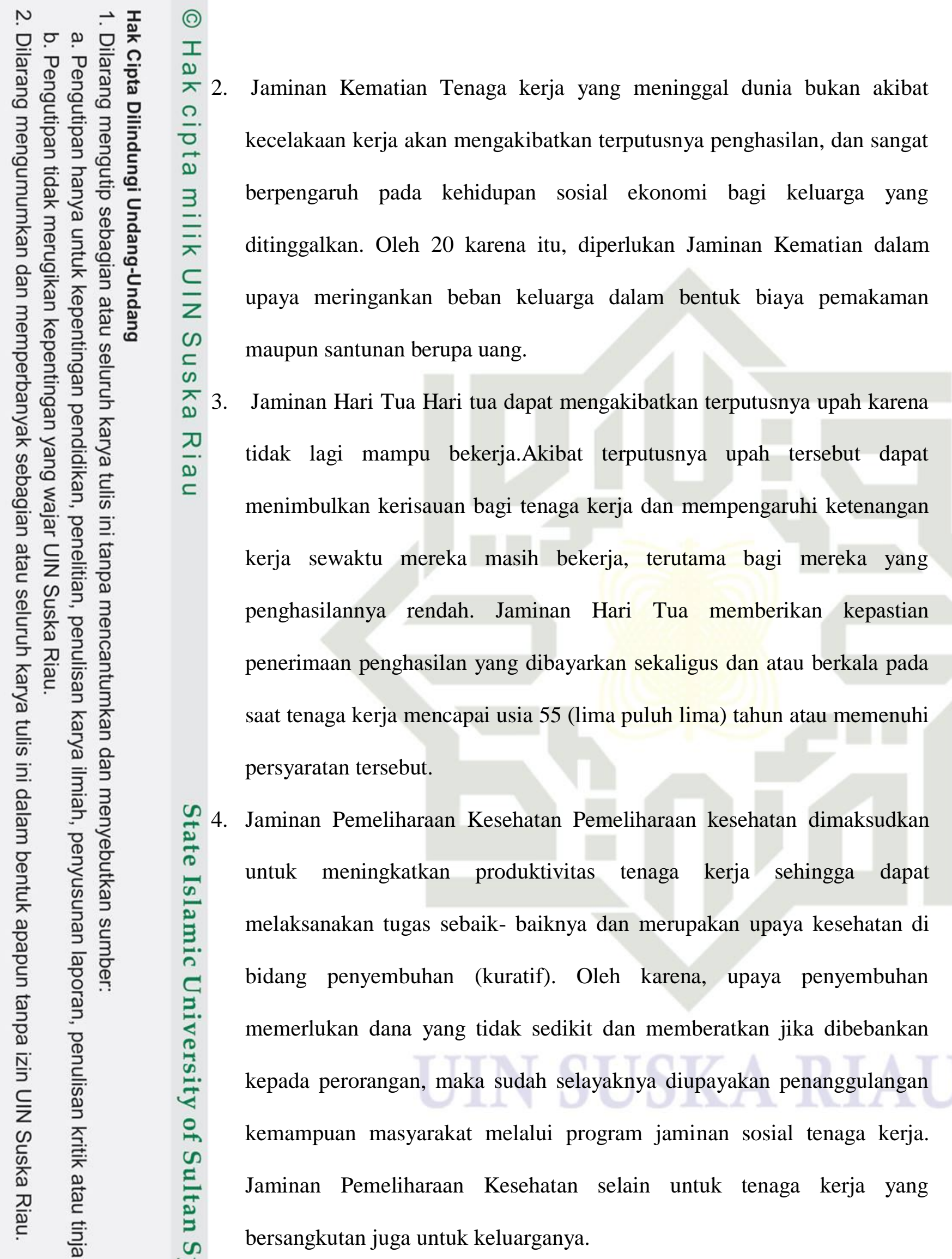




\section{Tugas dan Fungsi}

\section{Kepala Cabang Kantor}

Mengarahkan, mengevaluasi dan mengendalikan kegiatan operasional di Kantor Cabang, selaras dengan kebijakan dan strategi yang ditetapkan di Kantor Wilayah, guna memastikan pencapaian target Cabang dan wilayah secara optimal, sesuai dengan standar dan ketentuan yang berlaku diperusahaan.Wewenang yang dimiliki Kepala Kantor Cabang :

a. Memberikan persetujuan penempatan investasi dana di area kerjanya sesuai dengan batasan kewenangannya.

b. Merekomendasikan pembentukan Kantor Cabang kelas I Pembantu baru.

c. Merekomendasikan program PKP yang sesuai dengan kondisi Cabang kelas I

d. Mengajukan usulan mutasi dan promosi pegawai di Cabang kelas I untuk diajukan ke Kantor Wilayah

e. .Memberi persetujuan pengadaan barang dan jasa untuk Kantor Cabang kelas I sesuai dengan batas kewenangannya.

f. Memberikan persetujuan peremajaan sarana infrastruktur teknologi informasi.

g. Memberikan persetujuan pencairan anggaran rutin.

h. Menjadi perwakilan perusahaan di Cabang kelas I. 
(2)

工

즌 Kabid. Pemasaran Peserta PU (Penerima Upah) 
serta melakukan pembinaan kepada tim, guna memastikan tercapainya target kepesertaan dan iuran yang telah dibebankan.

b. Mereview data potensi dan/atau melaksanakan kegiatan pemasaran untuk mengakuisisi kepesertaan baru atau mendapatkan kembali peserta yang telah keluar dari kepesertaan (untuk masuk kembali menjadi peserta), serta melakukan pembinaan kepada tim, guna memastikan tercapainya target kepesertaan dan iuran yang telah dibebankan.

c. Mengumpulkan data potensi dan melaksanakan kegiatan pemasaran untuk mengakuisisi kepesertaan baru atau mendapatkan kembali peserta yang telah keluar dari kepesertaan (untuk masuk kembali menjadi peserta), guna memastikan tercapainya target kepesertaan dan iuran yang telah dibebankan.

d. Relationship Officer (RO)

e. Menyusun usulan rencana pengelolaan kepesertaan untuk tim-nya, mengkoordinasikan dan/atau melaksanakan kegiatan pembinaan kepada peserta (sebagai bagian dari program Customer Relationship Management / CRM), memberikan pelayanan dan menangani keluhan peserta dengan cepat dan tepat, serta melakukan pembinaan kepada timnya, guna tercapainya tertib administrasi, terjalinnya hubungan baik dengan peserta, dan meningkatkan kepesertaan dan iuran yang telah ditetapkan. 


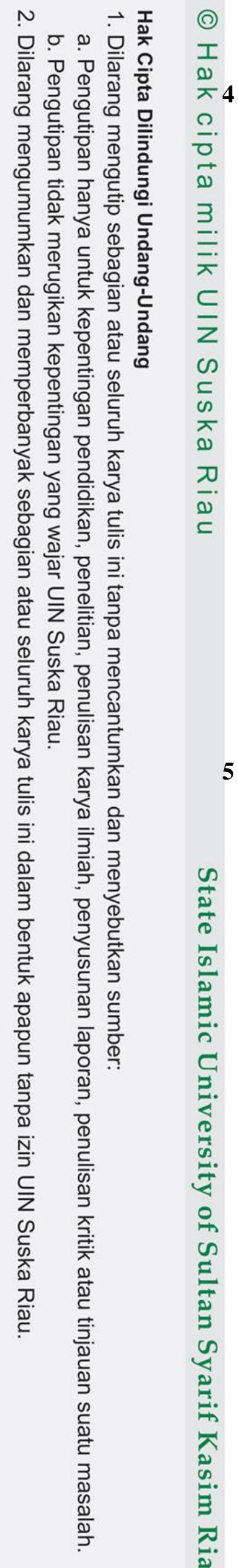

\section{Penata Madya Administrasi Pemasaran (PMAP)}

Menghimpun dan mengelola data yang terkait dengan kegiatan pemasaran dan administrasi kepesertaan, melakukan pelayanan dokumen administrasi dan penghitungan besar iuran serta denda (jika ada), guna menyediakan data yang akurat dan dokumen yang lengkap untuk mendukung kelancaran kegiatan pemasaran.Wewenang yang dimiliki Penata Madya Administrasi Pemasaran adalah :

a. Melakukan verifikasi dokumen pendukung dari calon peserta

b. Menginput data calon peserta serta pencetakan dokumen

c. Melakukan pengolahan data administrasi dan dokumen bagi peserta

d. Memberikan dukungan terhadap tugas Marketing/Relationship Officer

\section{Kabid. Pelayanan}

Merencanakan, mengkoordinasikan, memantau dan mengevaluasi penyelenggaraan dan pelayanan program JHT, JK, JPK dan JKK guna memastikan kegiatan pelayanan berlangsung lancar dan memenuhi standar kualitas yang ditentukan. Wewenang yang dimiliki Kabid. Pelayanan :

a. Menangani keluhan peserta dalam batas kewenangan.

b. Menyetujui pengeluaran anggaran rutin.

c. Melakukan negosiasi dalam batas kewenangannya.

d. Mengevaluasi kinerja petugas pelayanan 


\section{Penata Madya Jaminan Pelayanan JHT - JP}

Melakukan verifikasi terhadap dokumen pendukung proses klaim 51 program JHT \& JP, menentukan iuran pertama yang harus dibayar, menentukan besar klaim dan memproses klaim sesuai ketentuan yang berlaku, guna memenuhi kewajiban pembayaran klaim kepada peserta dengan tepat jumlah dan tepat waktu. Wewenang yang dimiliki Penata Madya Jaminan JHT - JP :

a. Menetapkan besaran klaim

b. Menolak pengajuan klaim yang belum memenuhi persyaratan

7 Penata Madya Jaminan Pelayanan JKK - JK

Melakukan verifikasi dokumen pendukung dan perhitungan biaya sesuai ketentuan dalam proses klaim program JKK- JK, menentukan besar klaim dan memproses klaim, serta memantau kinerja dan melakukan pembinaan kepada mitra PPK, guna memenuhi kewajiban proses klaim kepada peserta dengan tepat sasaran, tepat mutu dan tepat waktu. Wewenang yang dimiliki Penata Madya Jaminan JKK- JK:

a. Menetapkan besaran klaim

b. Menolak pengajuan klaim yang belum memenuhi persyaratan

c. Menyusun draft Perjanjian Kerjasama

\section{CSO (Customer Service Officer)}

Memberikan pelayanan kepada peserta maupun calon peserta sesuai kebutuhan (seperti pelayanan kepesertaan, iuran, pengajuan jaminan, permintaan informasi, dll), menangani keluhan peserta sesuai 


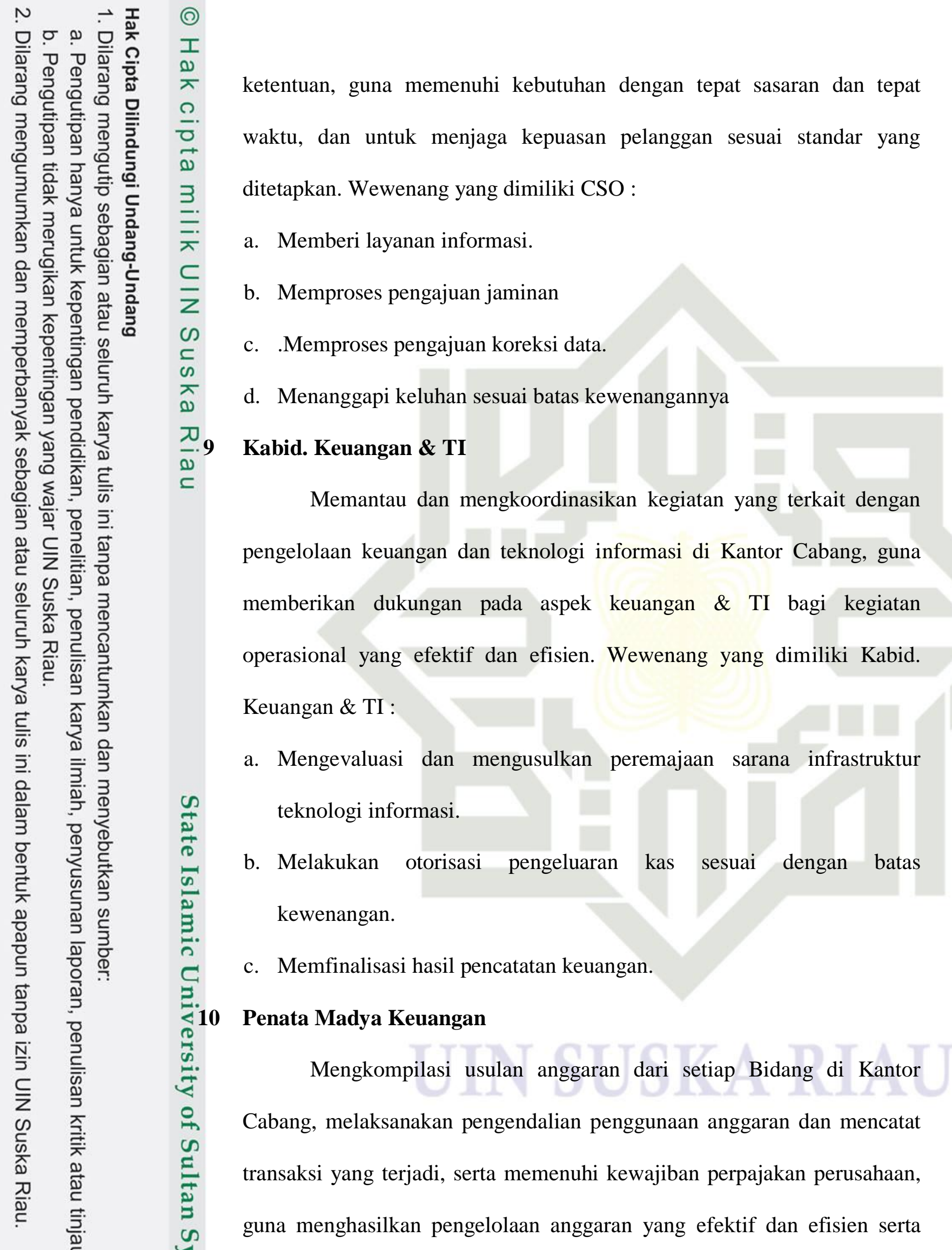


政

()

I

지

0 
Officer(RO) serta mengendalikan pelayanan administrasi kepesertaan, guna memastikan target kepesertaan serta iuran di bidang jasa konstruksi dan sektor informal di cabang tercapai dengan efektif dan efisien. Merencanakan dan mengkoordinasikan penerapan program PKP, selaras dengan strategi di Kantor Wilayah, guna efektivitas dan efisiensi program untuk mendukung kegiatan pemasaran. Wewenang yang dimiliki Kabid. Pemasaran Informal :

a. Menyusun strategi tindak lanjut atas potensi yang ada.

b. Mengajukan usulan target kepesertaan dan iuran.

c. Menyetujui penerbitan KPJ berdasarkan permintaan RO.

d. Menentukan target untuk setiap RO

e. Menangani keluhan peserta dalam batas kewenangan

f. Menyetujui pengeluaran anggaran rutin.

g. Mengajukan usul reward / punishment untuk RO.

h. Melakukan negosiasi dalam batas kewenangannya

13 Penata Madya Pemasaran BPU (Bukan Penerima Upah)

Melaksanakan kegiatan pemasaran (untuk mengembangkan kepesertaan) dan pembinaan kepada peserta di sektor informal dan, memberikan pelayanan dan menangani keluhan peserta dengan cepat dan tepat, guna memastikan tercapainya target kepesertaan dan iuran informal yang telah dibebankan dan untuk menjaga kepuasan peserta. Wewenang yang dimiliki Penata Madya Pemasaran BPU adalah : 


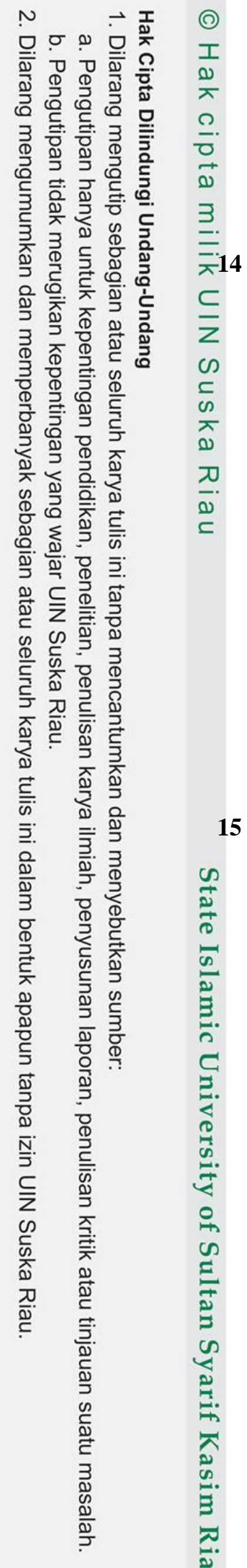

a. Melakukan kontak dengan calon peserta

b. Melakukan negosiasi dalam batas kewenangannya

c. Meminta data peserta

\section{Penata Madya Kesejahteraan Peserta}

Melaksanakan kegiatan pemasaran (untuk mengembangkan kepesertaan) dan pembinaan kepada peserta di sektor jasa konstruksi memberikan pelayanan dan menangani keluhan peserta dengan cepat dan tepat, guna memastikan tercapainya target kepesertaan dan iuran jasa konstruksi yang telah dibebankan dan untuk menjaga kepuasan peserta. Wewenang yang dimiliki Penata Madya Kesejahteraan Peserta adalah :
a. Melakukan kontak dengan calon peserta
b. Melakukan negosiasi dalam batas kewenangannya
c. Meminta data peserta

15 Kabid. Umum \& SDM

Memantau dan mengkoordinasikan kegiatan pengelolaan sumber daya manusia, pengadaan barang dan jasa, pemeliharaan aset dan pelayanan umum bagi pegawai (seperti rumah tangga, kebersihan, keamanan, kearsipan, dsb), serta hubungan komunikasi dengan pihak internal dan eksternal, guna memberikan dukungan pada aspek SDM \& Umum bagi kelancaran kegiatan bisnis di kantor cabang. Wewenang yang dimiliki Kabid. Umum \& SDM :

a. Menetapkan kandidat calon pegawai baru. 


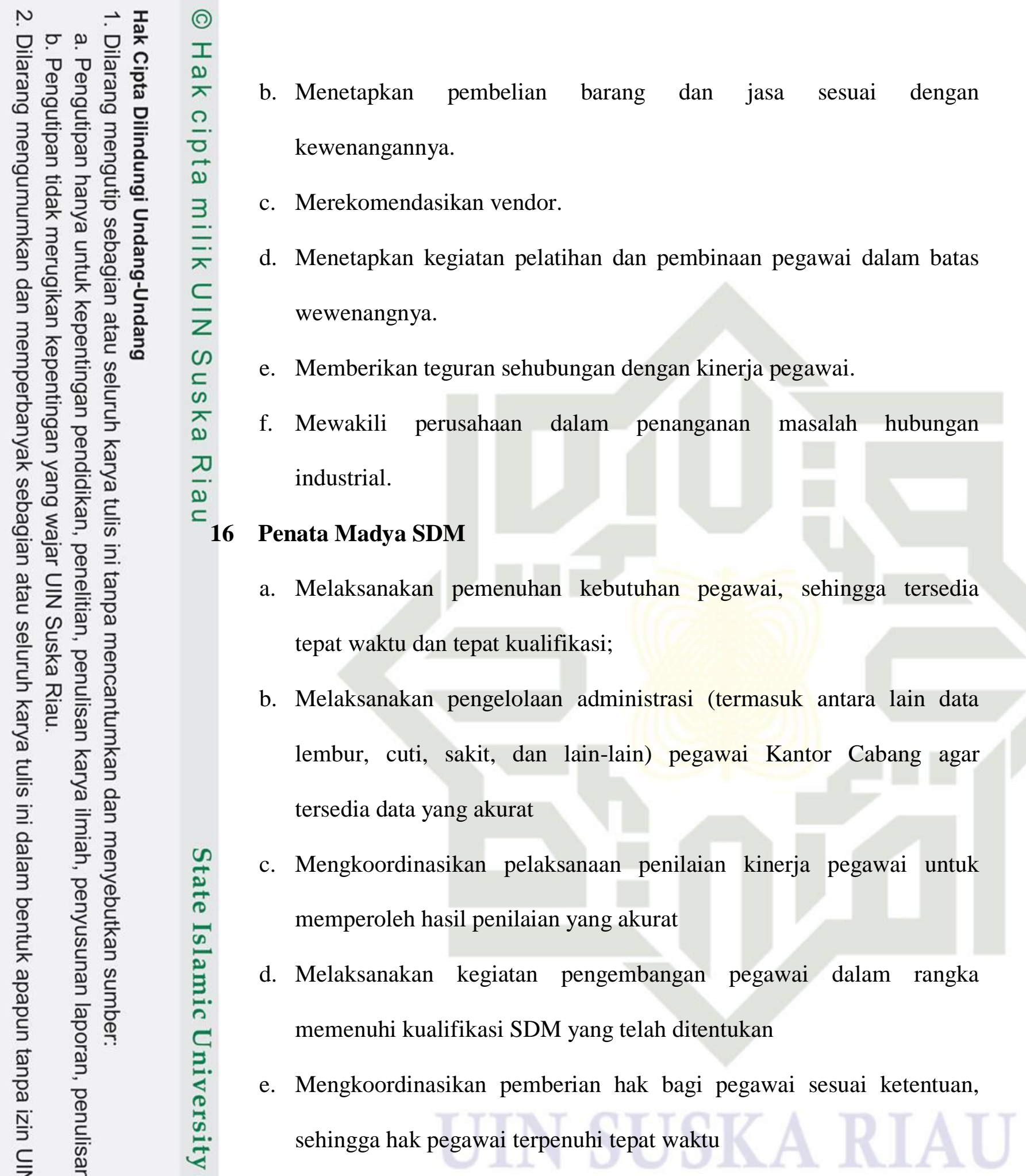




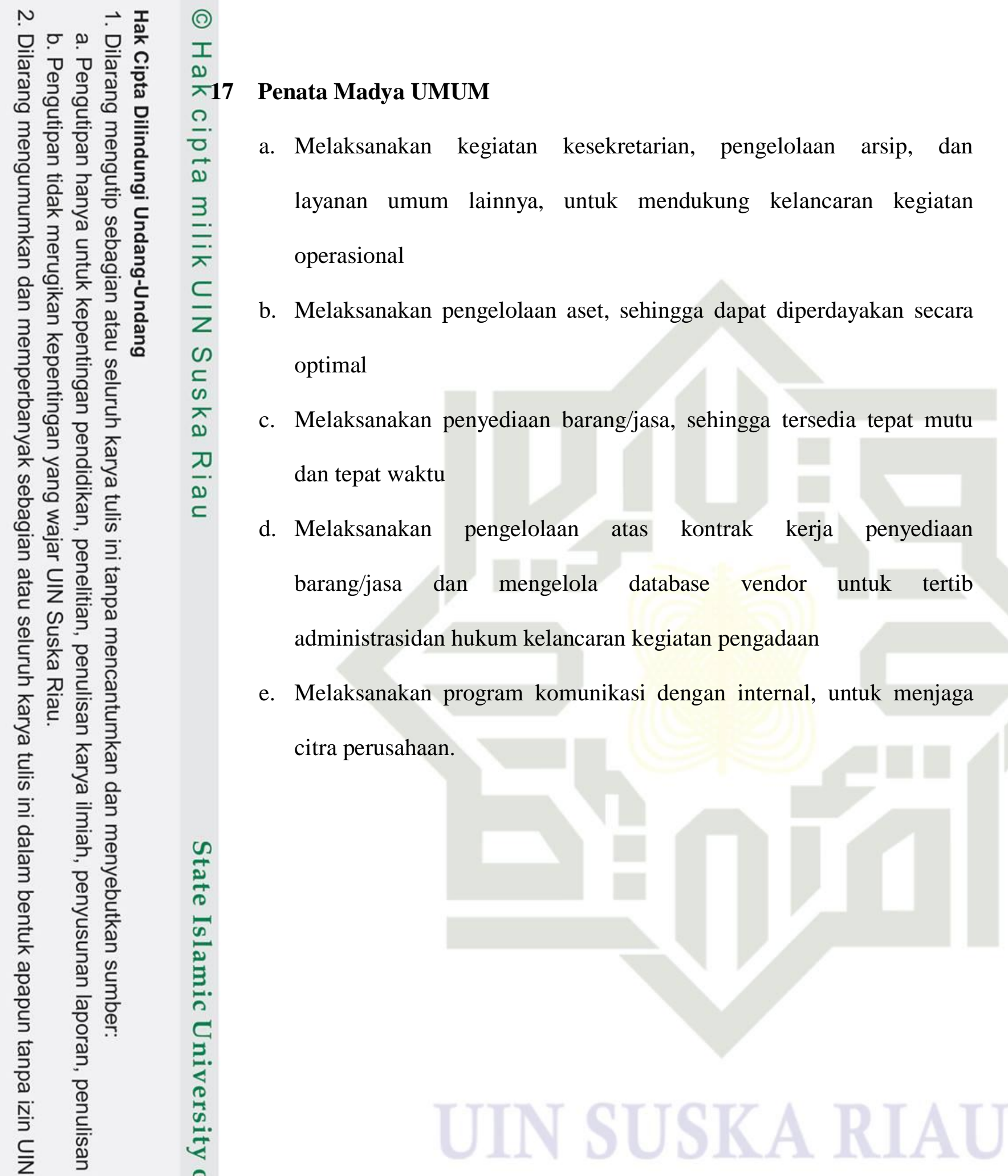



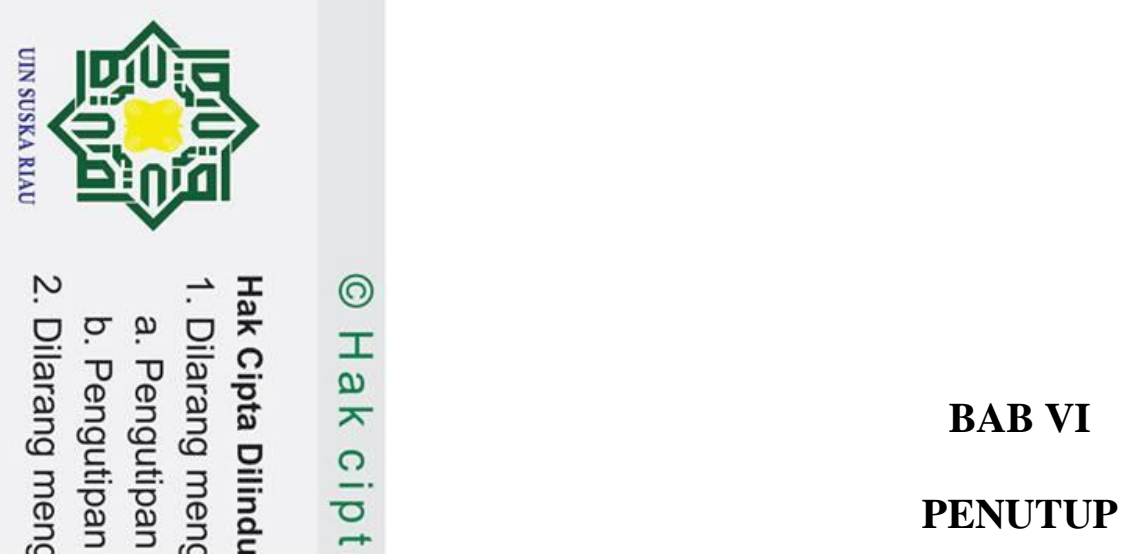

3.1 Kesimpulan

$\bar{x}$

Penelitian ini dilaksanakan untuk menguji pengaruh variabel kepuasan kerja, komitmen organsisi dan kinerja pegawai BPJS Ketenagakerjaan Cabang

Rekanbaru Panam. Dari hasil dan analisis data serta pembahasan pada bab त)

sebelumnya dapat disimpulkan sebagai berikut :

$\stackrel{\text { @) }}{\subseteq}$. Pengaruh Kepuasan Kerja (X1) terhadap variabel $(\mathrm{Y})$ menunjukkan nilai $\mathrm{t}$ hitung $(5,290)>\mathrm{t}$ tabel $(2.07387)$ dengan nilai signifikan yang dihasilkan sebesar 0,000 masih berada dibawah 0,05. Hal ini menunjukkan bahwa kepuasan kerja memiliki pengaruh yang positif dan signifikan terhadap kinerja pegawai BPJS ketenagakerjaan Cabang Pekanbaru Panam

2. Pengaruh komitmen organisasi (X2) terhadap variabel (Y) menunjukkan nilai $\mathrm{t}$ hitung (4.079) > $\mathrm{t}$ tabel (2.07387) dengan nilai signifikan yang dihasilkan sebesar 0,000 masih berada dibawah 0,05. Hal ini menunjukkan bahwa komitmen organisasi memiliki pengaruh yang positif dan signifikan terhadap kinerja pegawai BPJS ketenagakerjaan Cabang Pekanbaru Panam.

3. Nilai $F_{\text {hitung }}(25.026)>F_{\text {tabel }}(3,44)$ dengan signifikan $0,000<0,05$. Artinya secara simultan atau bersamaan kepuasan kerja dan komitmen organisasi memiliki pengaruh positif dan signifikan terhadap kinerja pegawai BPJS ketenagakerjaan Cabang Pekanbaru Panam. 


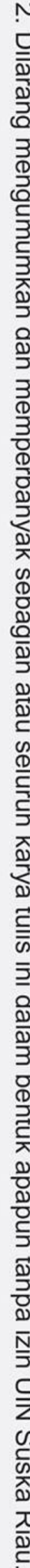

工

죽 4. nilai adjusted R Square sebesar 0,667 atau $66,7 \%$ berarti kepuasan kerja 0 dan komitmen organisasi dapat mempengaruhi kinerja pegawai BPJS ketenagakerjaan Cabang Pekanbaru Panam sebesar 66,7\% sementara sisanya sebesar 33,3\% dipengaruhi oleh variabel lain yang tidak digunakan dalam penelitian ini.

\section{Saran}

Berdasarkan kesimpulan di atas, dapat dikemukakan beberapa saran yang $\nabla$ đîharapkan dapat bermanfaat bagi perusahaan maupun bagi pihak-pihak lain. Adapun saran yang diberikan, antara lain:

1. Berdasarkan pada penelitian ini diharapkan kepada BPJS Ketenagakerjaan Cabang Pekanbaru Panam untuk memperhatikan kepuasan kerja untuk meningkatkan kinerja pegawai, agar terjadinya timbal balik (feedback) bagi perusahaan.

2. Sebaiknya BPJS Ketenagakerjaan Cabang Pekanbaru Panam lebih memperhatikan komitmen organisasi pegawai agar dapat meningkatkan kinerja.

3. Bagi peneliti selanjutnya harus lebih mengembangkan lagi variabelvariabel yang akan diteliti dengan memperhatikan variabel mana yang dapat mempengaruhi kinerja sehingga penelitian yang dihasilkan lebih berkembang dan lebih baik. 


\section{DAFTAR PUSTAKA}

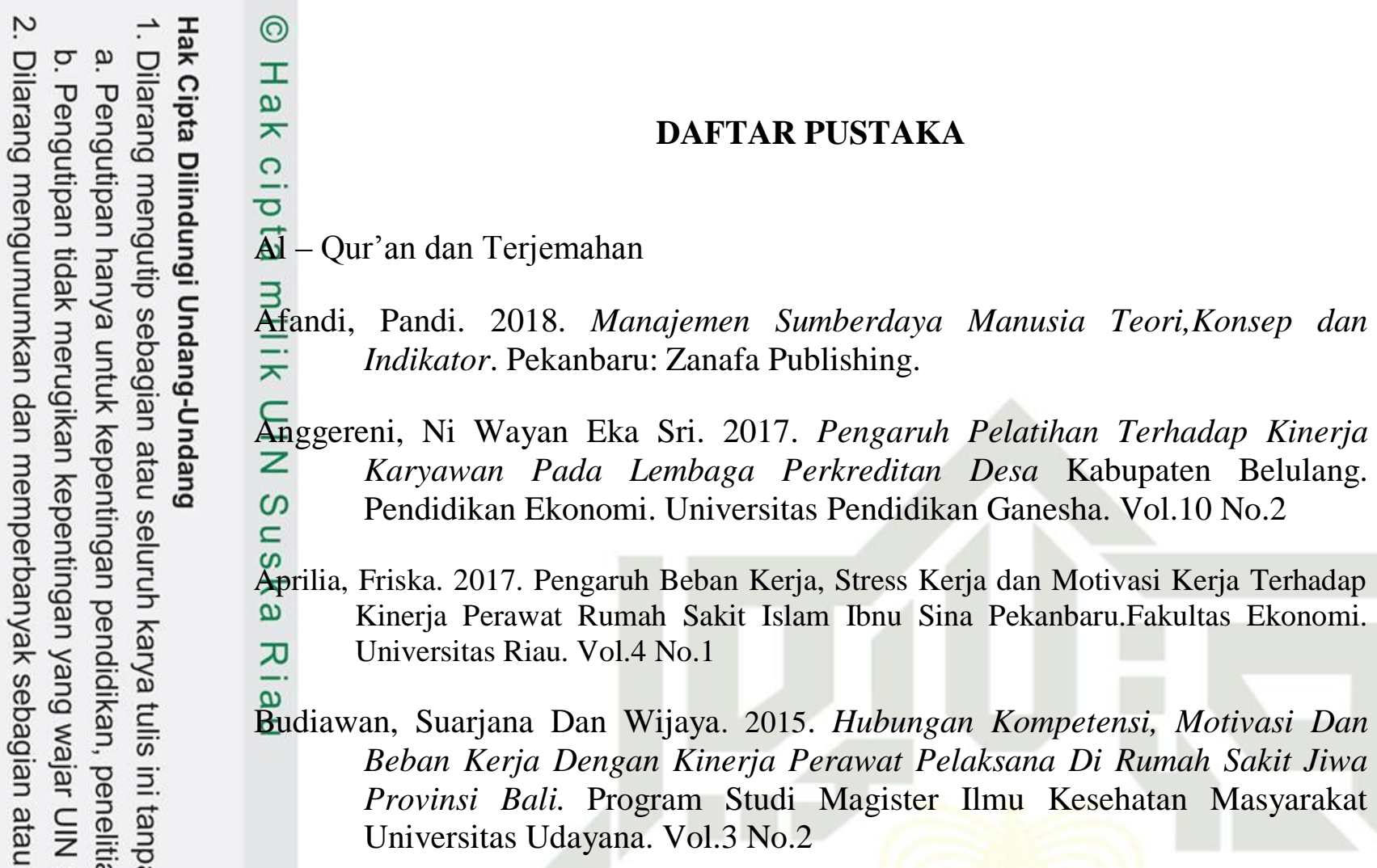

Chang, Wiliam. Metologi Penulisan Esai, Skripsi, Tesis, dan Disertasi untuk Mahasiswa. Jakarta: Erlangga, 2014.

Dewi, Mardiani. 2015. Pengaruh kepuasan kerja dan komitmen organisasional terhadap kinerja pegabai bank Kalsel:(http://jwm.ulm.ac.id)diakses pada 10 Januari 2019 )

Edison Emron, Yohny Anwar dan Imas Komariah., 2016., Manajemen Sumber \& Daya Manusia, Alfabeta, Bandung.

$\stackrel{7}{2}$

Elisabeth, Manuho, Herman Warouw Dan Rivelino Hamel. 2015. Hubungan o Beban Kerja Dengan Kinerja Perawat Dalam Pemberian Asuhan . Keperawatan Di Instalasi Rawat Inap C1 Rsup Prof. Dr. R. D. Kandou छ. Manado. Program Studi Ilmu Keperawatan, Fakultas Kedokteran. Universitas Sam Ratulangi. Vol.3 No.2

G̈hozali, Imam.2013. AplikasiAnalisis Multivariate denganProgram SPSS. Semarang: B-PUNDIP.

H. Handoko, Hani. 2011. Manajemen Personalia dan Sumber Daya Manusia. Y Yogyakarta: BPFE.

fearini, Sri. Sudarijati. Dan Kartiwi Niken. 2018. Worload, Work Environment F and Employee Performance of Housekeeping. Departement of Management, Djuanda University, Jl. Tol Ciawi No. 1, Bogor, Indonesia Vol.3 


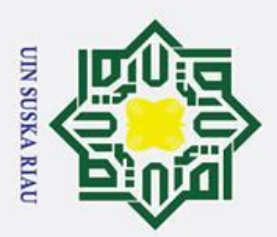

Hăriyati, Tutik Sri. 2013. Perencanaan dan Pengembangan dan utilitas Tenaga ‥ Keperawatan. Jakarta: PT Raja Grafindo Persada.

Hुasibuan. Melayu.2013. Manajemen Sumber Daya Manusia Edisi Revisi. Jakarta $3 \quad$ : Bumi Aksara.

H̆usein Umar. (2011). Metode Penelitian untuk Skripsi dan Tesis Bisnis. Jakarta: Rajawali Pers.

畐drayani, Henni. Mahyarni. Meflinda, Astuti. Nurfaisal.2013. Manajemen ( Sumberdaya Manusia Terintegrasi. Pekanbaru: Suska Press.

ᄃ

f̊Rko Utomo, Suwardi. 2011. Pengaruh Motivasi Kerja, Kepuasan Kerja, dan a Komitmen Organisasional terhadap Kinerja Pegawai (Studi pada Pegawai ㄲ. Setda Kabupaten Pati. Universitas Muria Kudus. Dipublikasikan.

a).

Malayu S.P Hasibuan. (2013). Manajemen Sumber Daya Manusia Perusahaan. Jakarta: Bumi Aksara.

Moeheriono. 2012. Pengukuran Kinerja Berbasis Kompetensi. Jakarta: Raja Grafindo Persada.

Muslim Hr Bukhari Al-Qur'an dan Terjemahan.

Nimran, Umar dan Amirullah. 2011. Manajemen Sumber Daya Manusia \& Perilaku Organisasi. Malang : Sinar Akademika.

Novita. 2011. Pengaruh kepuasan kerja dan komitmen organisasional terhadap kinerja pada PT. Telekomunikasi Indonesia Tbk ritel Jatim Selatan.: * (http://jurnal.ugm.ac.id) diakses pada 12 Januari 2019 )..

Riving

Rivai, vaithzal.2011 manajenem sumber daya manusia untuk perusahaan dari teori

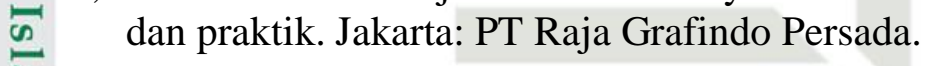

Riñvai, Veithzal. (2011). Manajemen Sumber Daya Manusia Untuk Perusahaan Dari Teori Ke Praktek. PT. Rajagrafindo Persada, Jakarta.

Robbins Stephen P. dan Judge Timothy A., 2015, Perilaku Organisasi, Edisi 16, Jakarta: Salemba Empat.

Röbbins, Stephen P dan Timothy A. Judge. (2011). Perilaku Organisasi. Jakarta: Salemba Empat.

Ŕobbins, Stephen P. dan Coulter M. 2010. Manajemen, Edisi Kesepuluh, Jakarta Erlangga.

Robert Kreitner dan Angelo Kinicki, 2014, Perilaku Organisasi, Edisi 9, Buku ke1, Jakarta: Salemba Empat. 

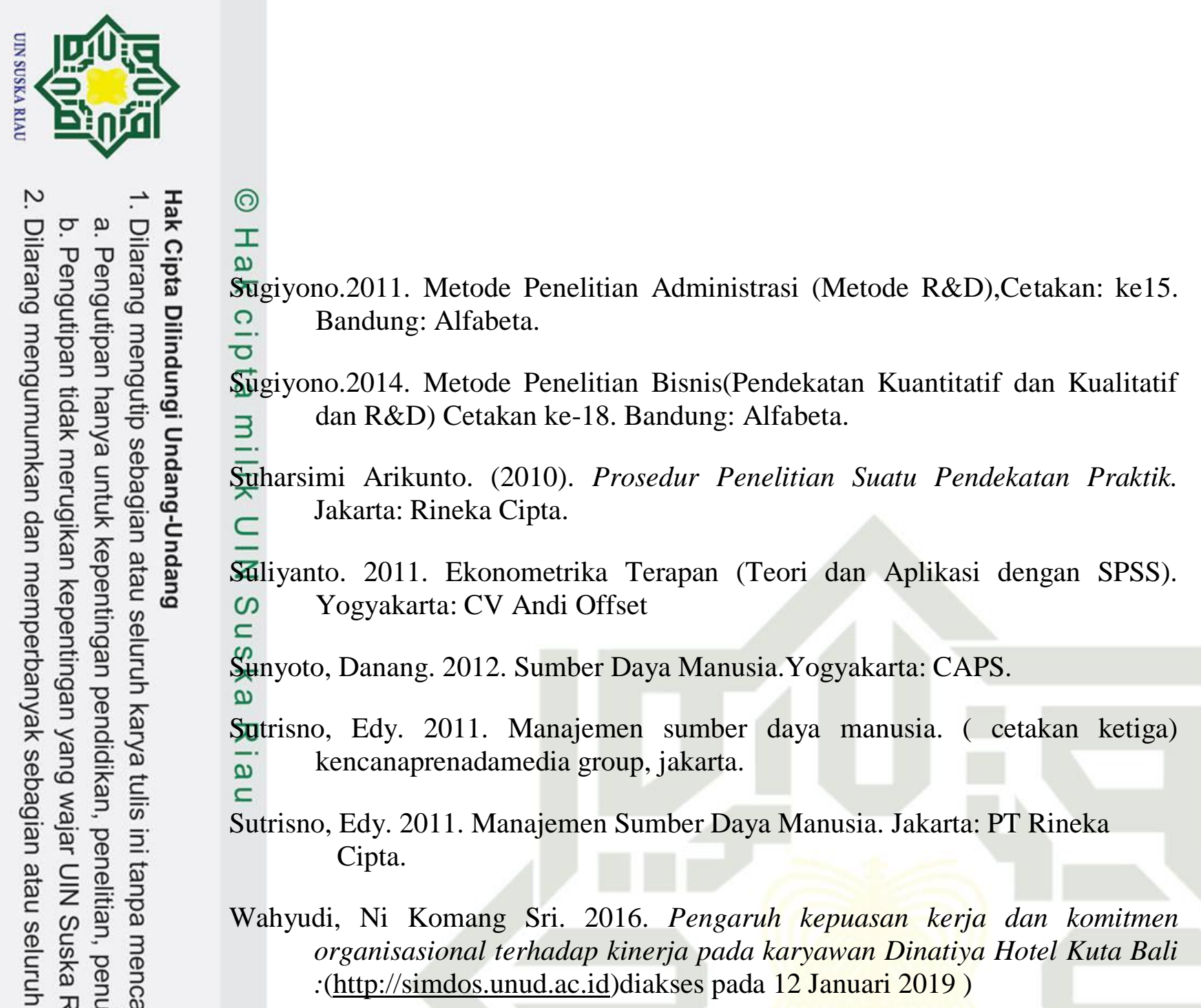

Wibowo. 2011. Manajemen Kinerja, Jakarta: Penerbit PT. Raja Grafindo. 

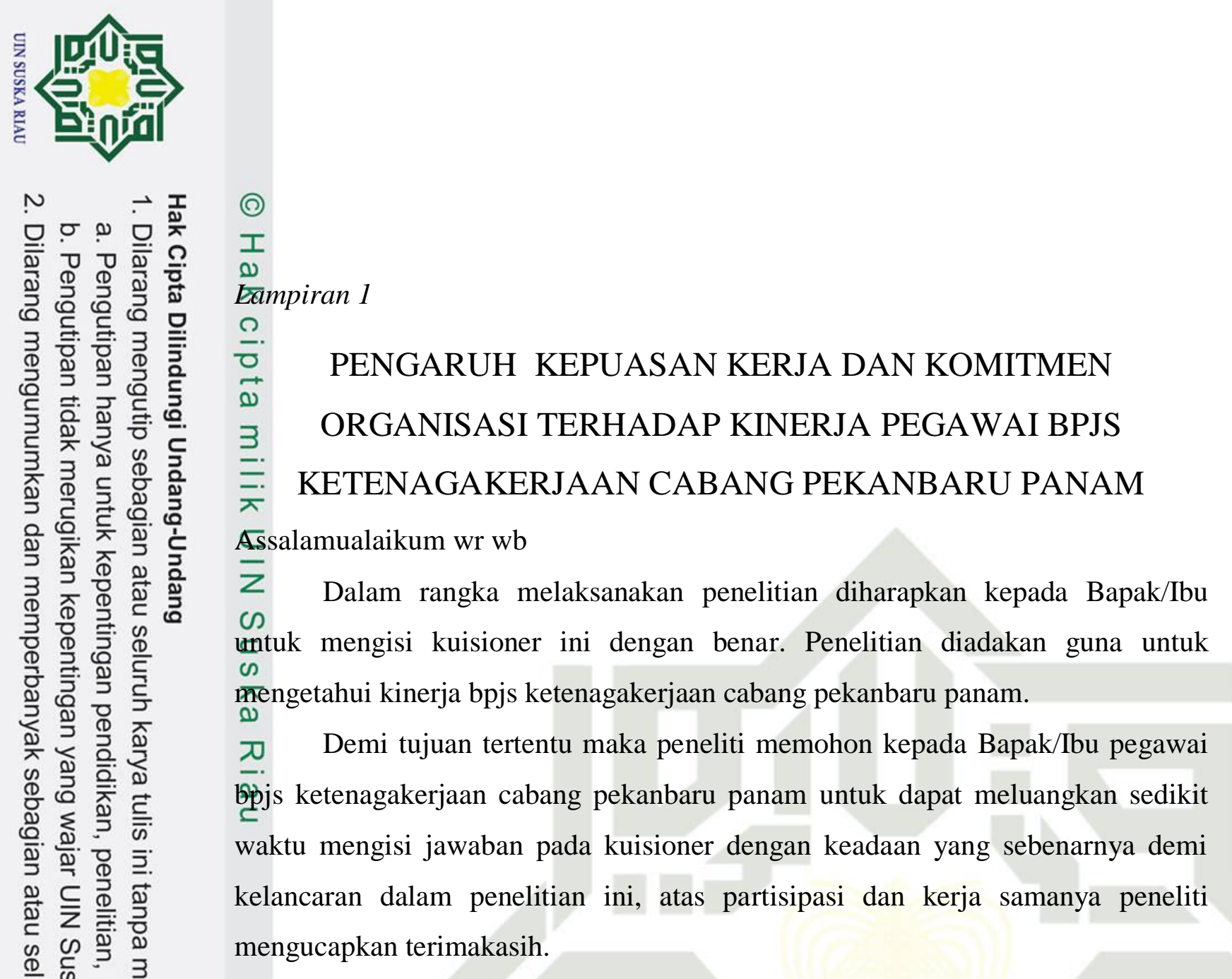

Semua informasi yang diperoleh dari kuesioner ini akan digunakan untuk keperluan penelitian saja. Terimakasih atas kerjasama yng telah diberikan. Wasallam

\section{IDENTITAS RESPONDEN}

N (Petunjuk : isilah titik - titik dibawah ini atau berikan tanda $\sqrt{ }$ paada kotak

pilihan yang menurut saudara sesuai dengan kondisi yang ada)
a. Nama
b. Jabatan
c. Pendidikanterakhir :... (D3)......(S1)......(S3)...lainya.
d. Jenis kelamin : $\square$ laki- laki $\square$ perempuan

e. Umur 

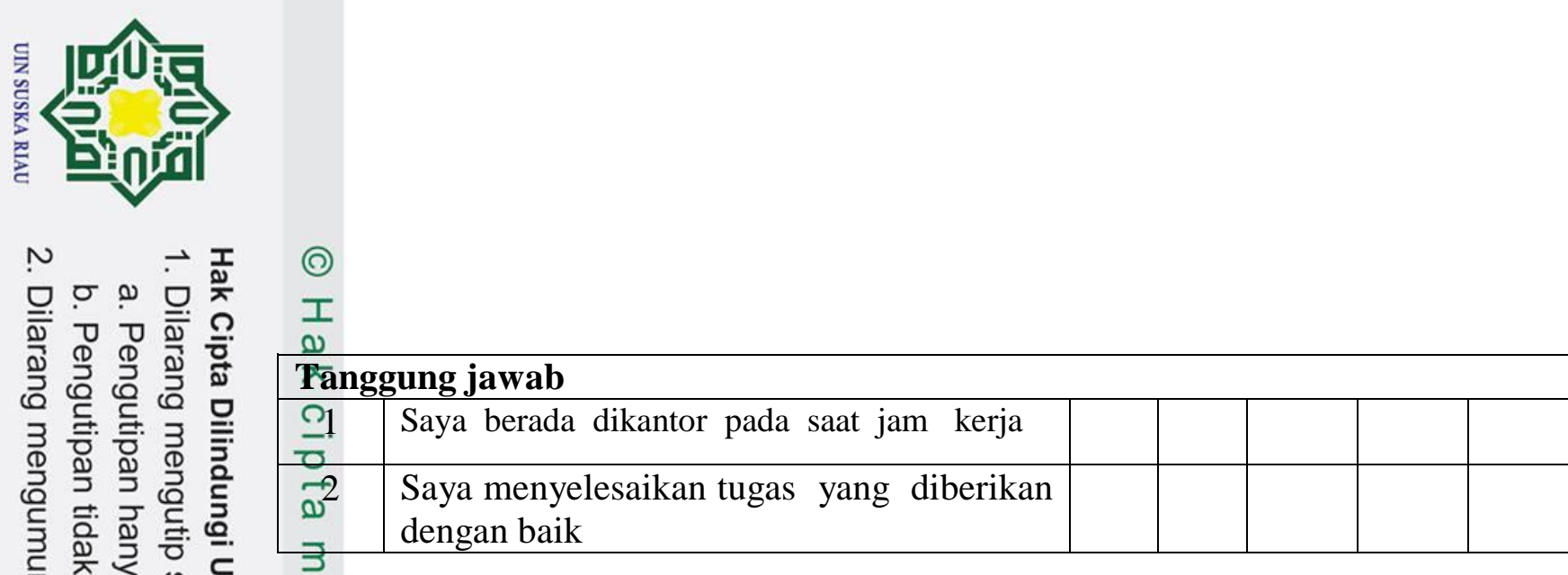

उ

\section{Kepuasan kerja (X1)}

Keterangan

() SS = Sangat Setuju

$\mathrm{TS}=$ Tidak Setuju

$\mathrm{S} \quad=$ Setuju

STS = Sangat Tidak Setuju

$\mathrm{N} \quad=$ Netral

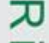

()

$\ulcorner$ Bacalah pertanyaan dengan teliti dan pilihlah jawaban yang menurut anda benar, dan berikan tanda checklist $(\sqrt{ })$ untuk jawaban atas pertanyaan berikut ini :

\begin{tabular}{|c|l|c|c|c|c|c|}
\hline & \multicolumn{1}{|l|}{ SS } & S & N & TS & STS \\
\hline Gaji & $\begin{array}{l}\text { Gaji yang tinggi dapat meningkatkan } \\
\text { semangat kerja saya }\end{array}$ & & & & \\
\hline $\begin{array}{l}\text { Saya merasa puas apabila perusahaan } \\
\text { memberikan gaji yang tinggi. }\end{array}$ & & & & \\
\hline
\end{tabular}

\section{Promosi}

\begin{tabular}{|c|c|c|c|c|c|c|}
\hline 0 & & SS & $\mathbf{S}$ & $\mathbf{N}$ & TS & STS \\
\hline$\frac{7}{2}$ & $\begin{array}{l}\text { Promosi ditempat kerja } \\
\text { secara obyektif }\end{array}$ & & & & & \\
\hline$\frac{2}{2}$ & $\begin{array}{l}\text { Kebijakan promosi (kenaikan pangkatatau } \\
\text { jabatan) ditempat kerja saya belum sesuai }\end{array}$ & & & & & \\
\hline \multicolumn{7}{|c|}{ Supervisi (hubungan dengan atasan) } \\
\hline ç & $\begin{array}{l}\text { Atasan dalam menilai prestasi kerja pegawai } \\
\text { secara obyektif }\end{array}$ & & & & & \\
\hline 2 & $\begin{array}{l}\text { Atasan dalam memberikan peringatan } \\
\text { kepada pegawai kurang tegas }\end{array}$ & & & & & \\
\hline$\frac{3}{4}$ & $\begin{array}{l}\text { Atasan dalam menegakkan disiplin sangat } \\
\text { tegas }\end{array}$ & & & & & \\
\hline \multicolumn{7}{|c|}{ Punjangan tambahan } \\
\hline W & $\begin{array}{l}\text { Prestasi kerja saya dihargai dengan bonus } \\
\text { tahunan }\end{array}$ & & & & & \\
\hline $\begin{array}{c}2 \\
\omega\end{array}$ & 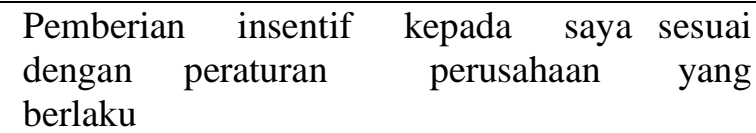 & & & & & \\
\hline
\end{tabular}



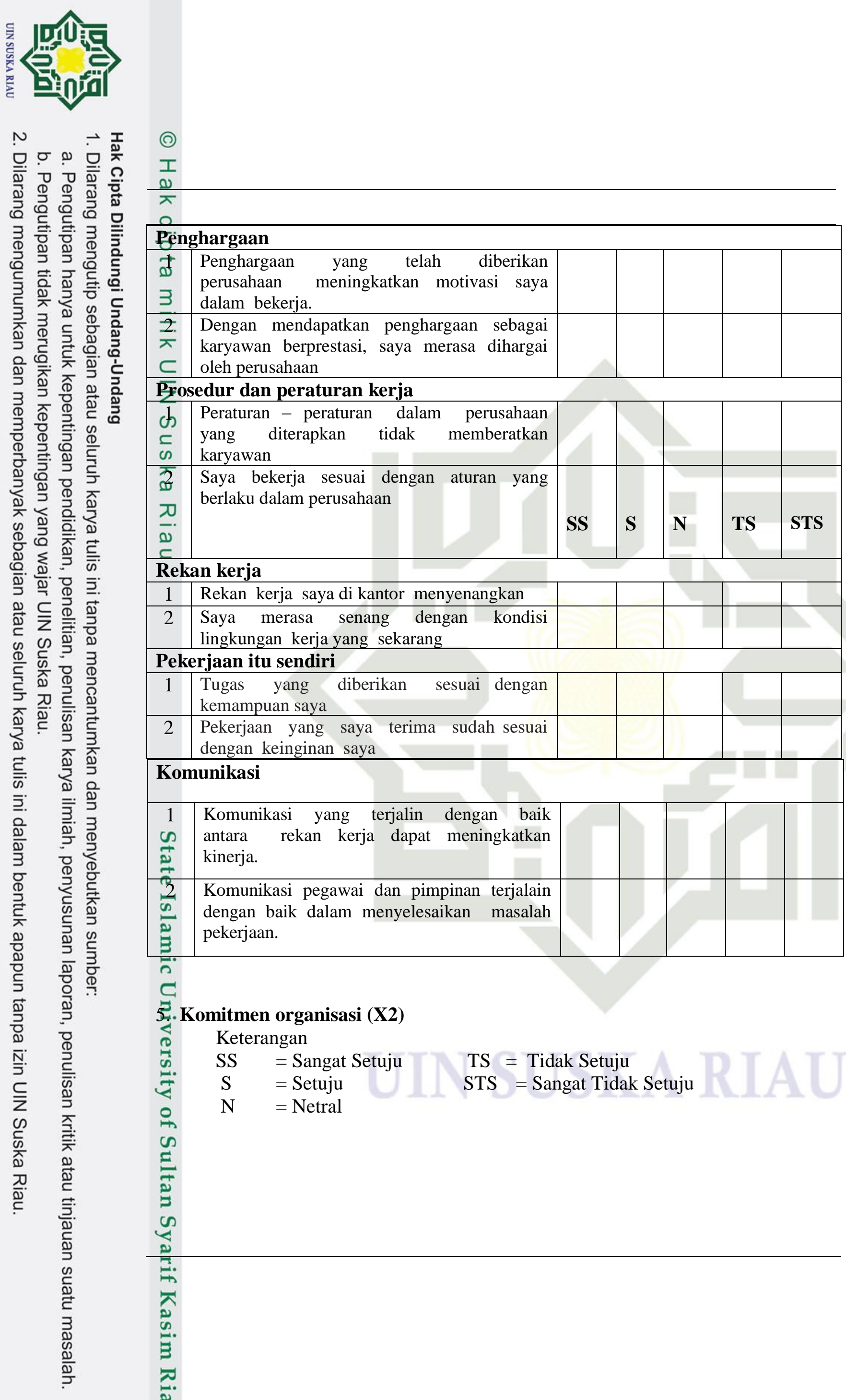

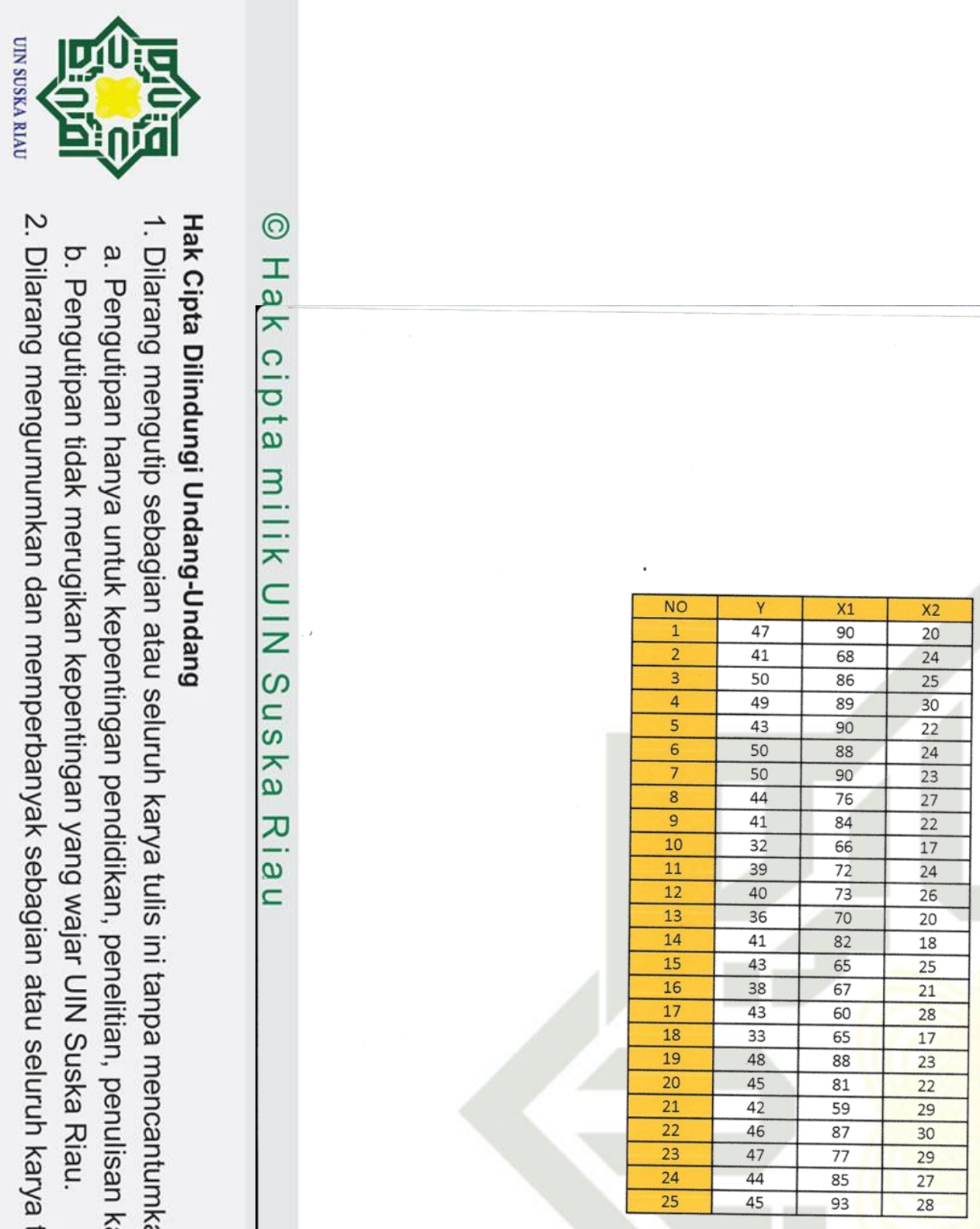

竞 严

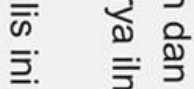

용.

光

豈 旅

듯 की

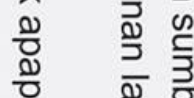

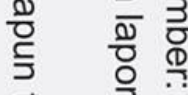

苛 ฏ

¿

N.

$\sum_{0}$ 쵸

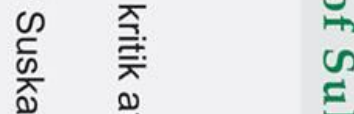

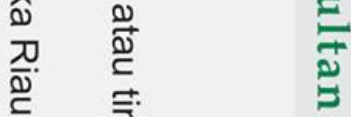

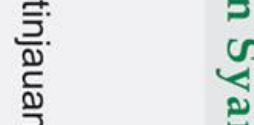

(⿻)

$\stackrel{0}{\rightleftarrows}$

क

E

D. 

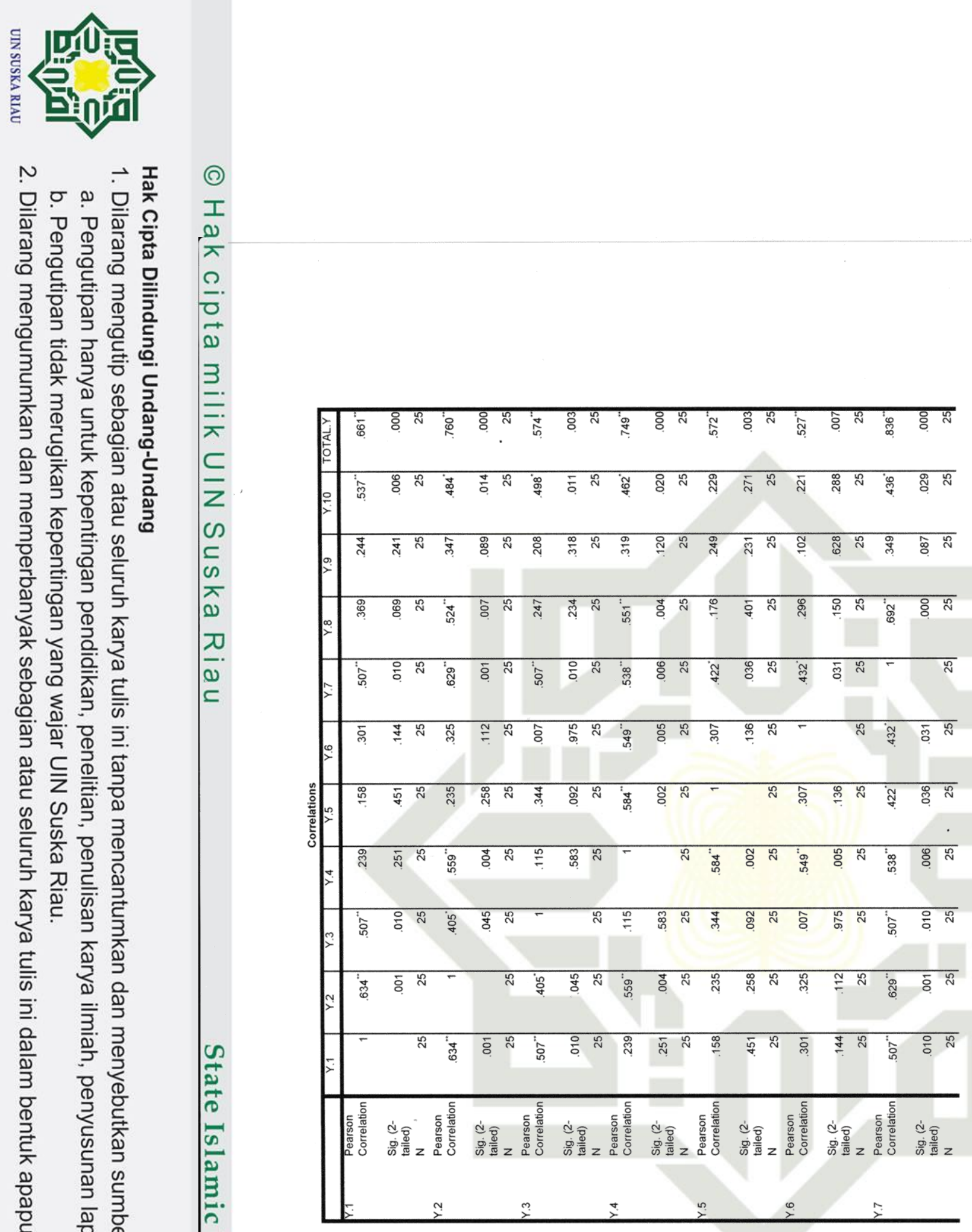

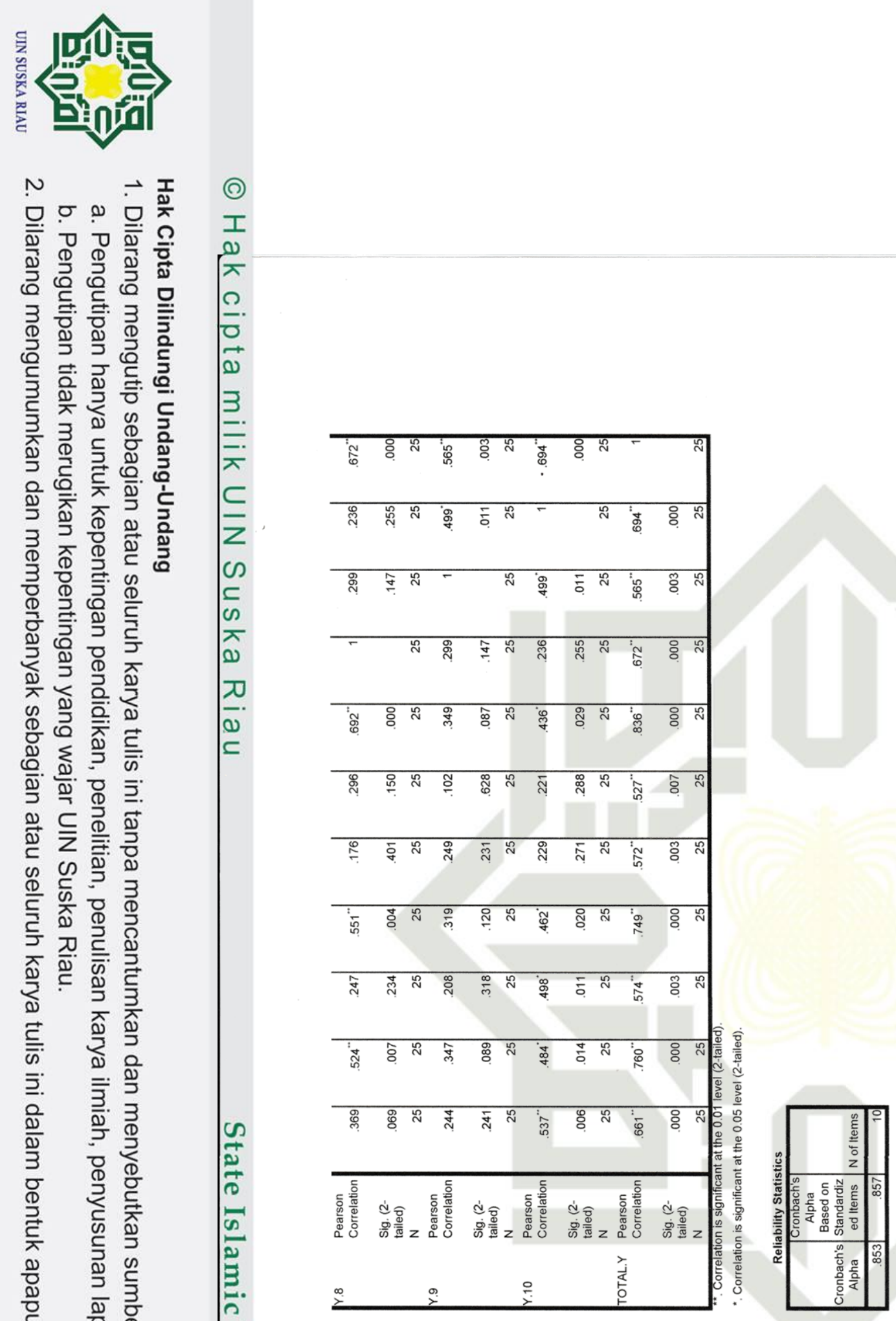


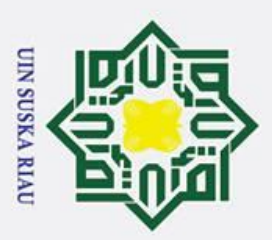

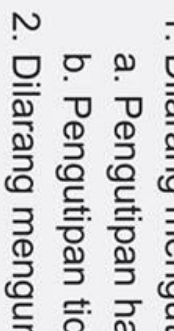

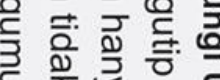

క

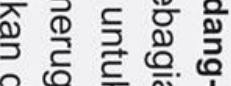

으으. 듯 잉.

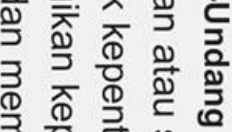

苋

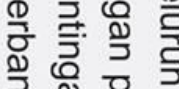

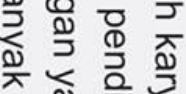

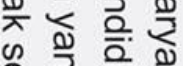

응

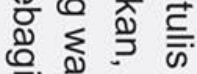

I

䒚 兽

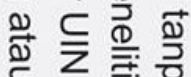

क ल खे

跑

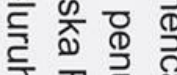

于 끌 를

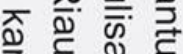

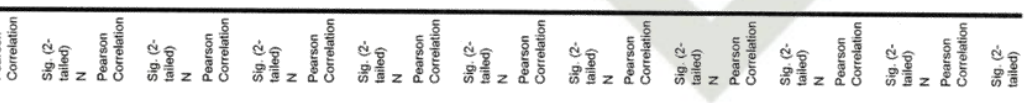




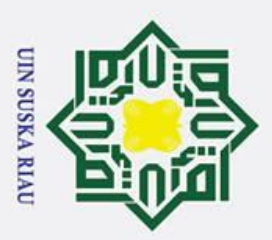

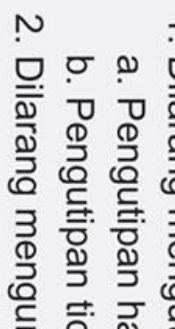

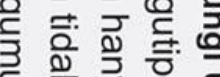

亲

ป ญ

등 (2)

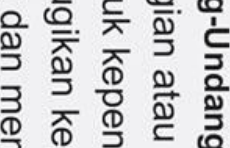

(1)

员 芯思

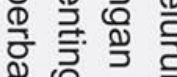

วิ

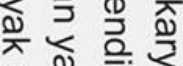

थ

¿

坣

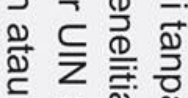

क

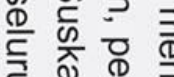

亭旸焉

不 谣

工

윰 줌

ट 질

क ऐे

三.

ฏิ

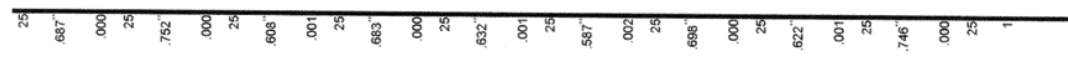

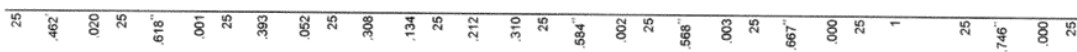

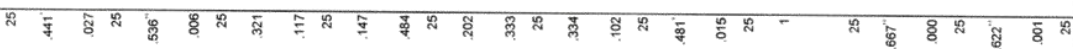

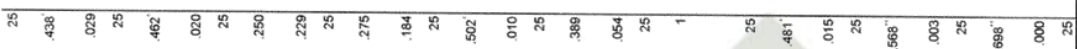

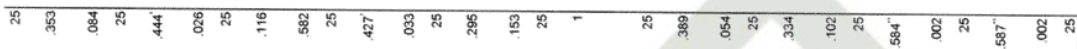

एूल

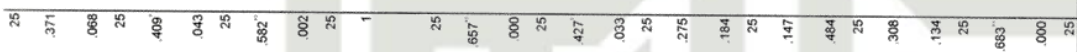

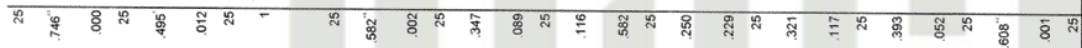

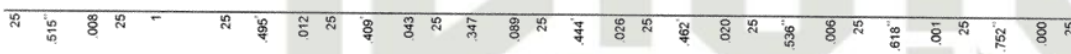

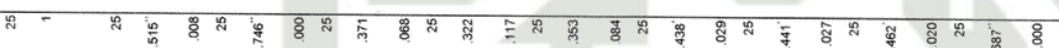

य

प्र

प्र

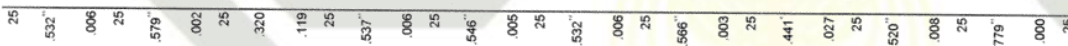

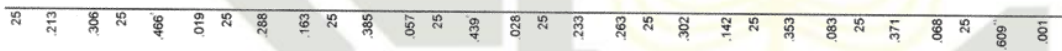

म

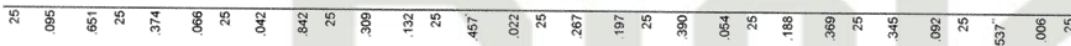

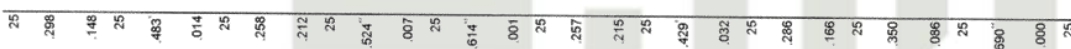

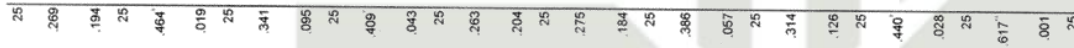

क्र

لIt

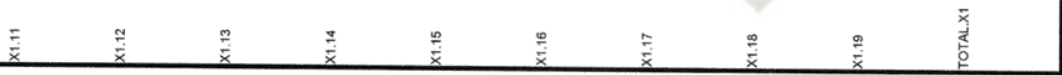




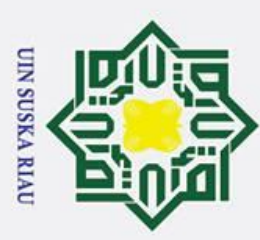

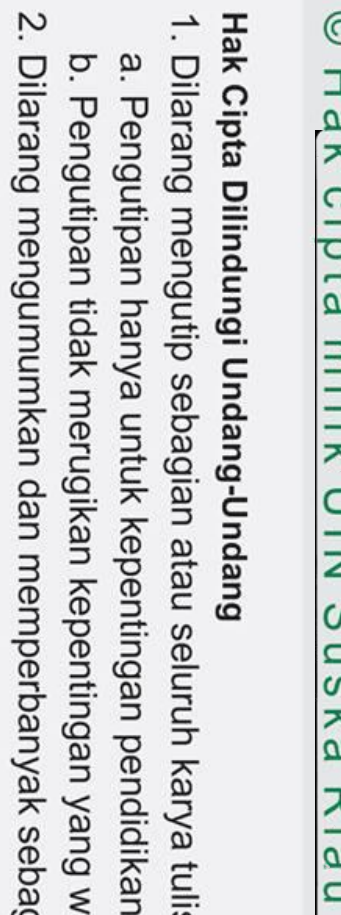

익 익

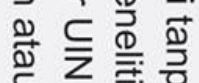

ल ब

舟

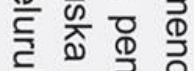

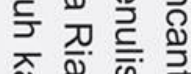

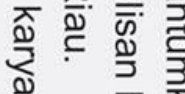

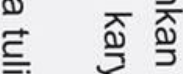

इ. ऐे ฏे

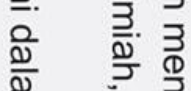

3 ర্

郘

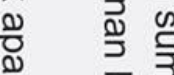

与 은

รั)

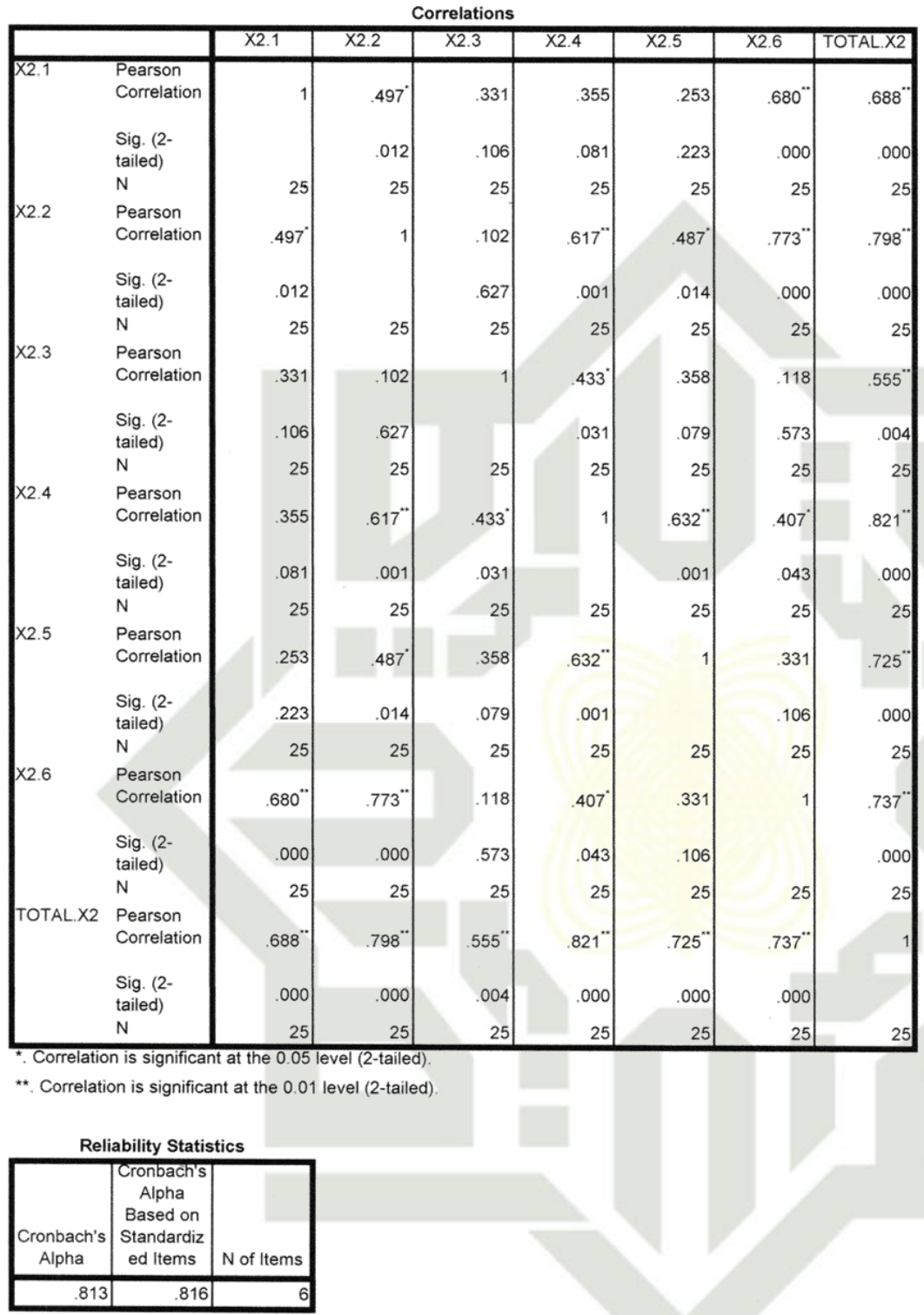



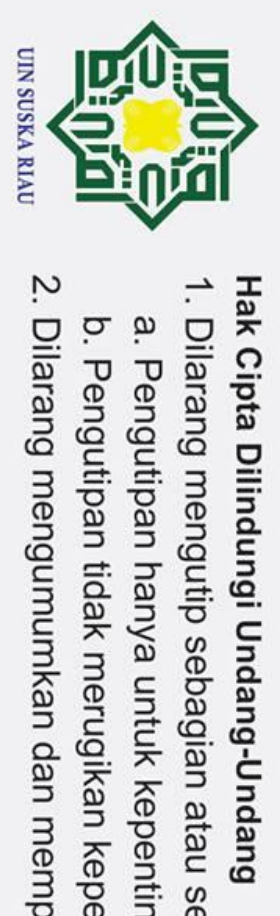

Analisis Deskriptif

\begin{tabular}{|l|r|r|r|r|r|}
\hline & N & Minimum & Maximum & Mean & Std. Deviation \\
\hline Kinerja & 25 & 32 & 50 & 43.08 & 4.966 \\
Kepuasan Kerja & 25 & 59 & 93 & 78.04 & 10.706 \\
Komitmen Organisasi & 25 & 17 & 30 & 24.04 & 3.910 \\
Valid N (listwise) & 25 & & & & \\
\hline
\end{tabular}

\section{2.. Asumsi Klasik}

()

\section{a. Normalitas Data}

u

त)

D

)

잉휴 을

일 至

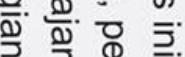

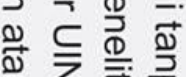

之

क ल ڤ

क की

足

与

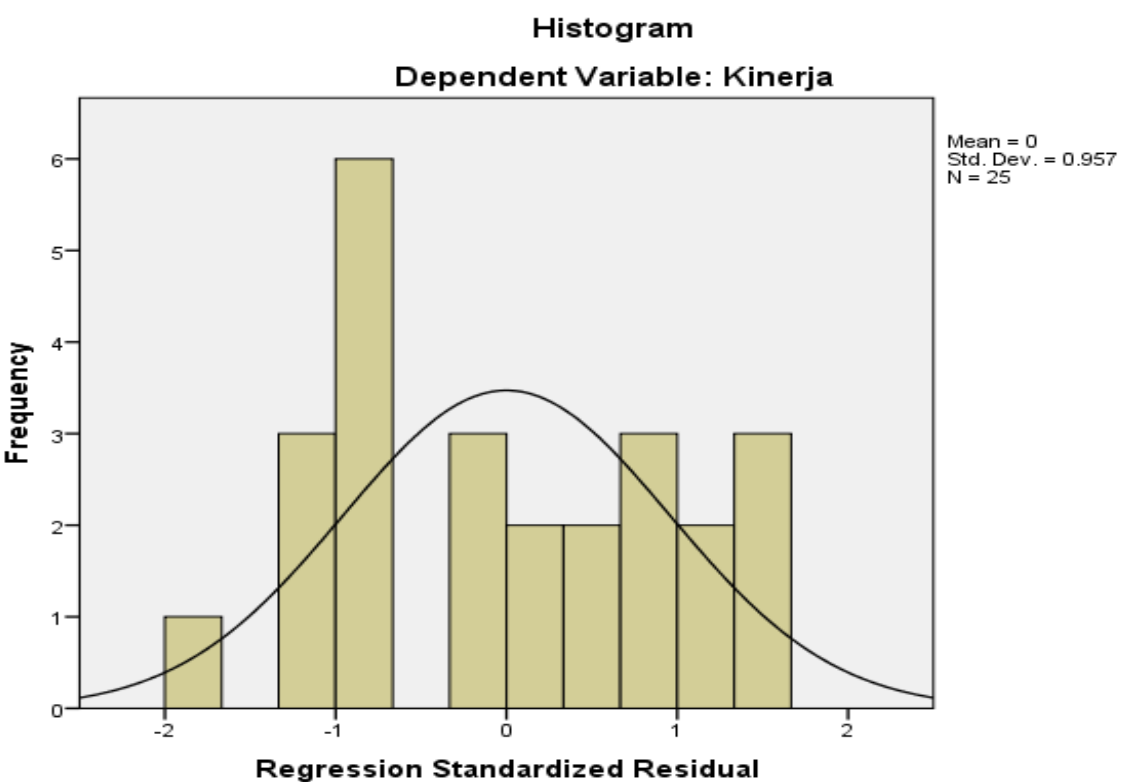

$\frac{\sqrt{2}}{n}$
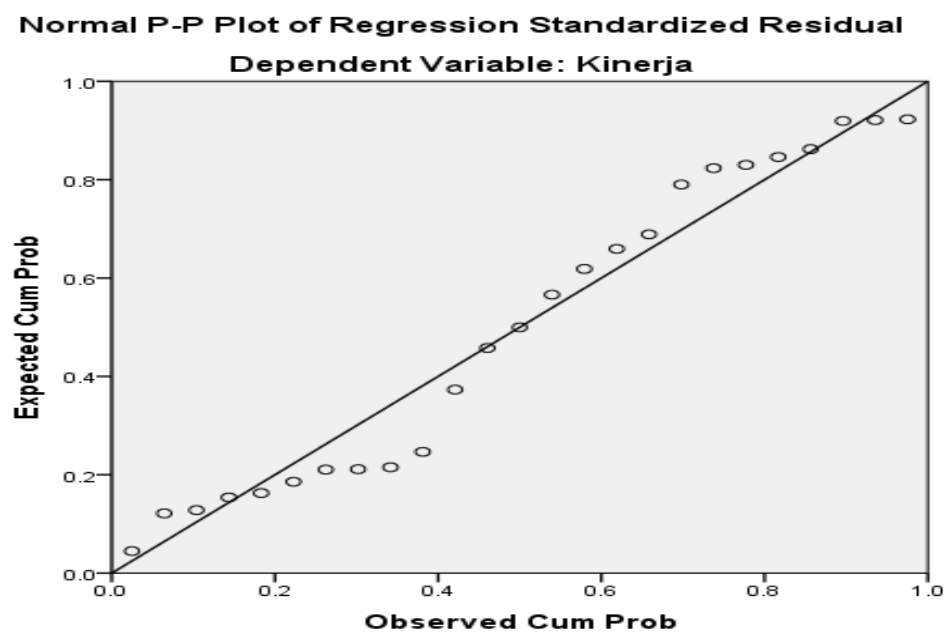

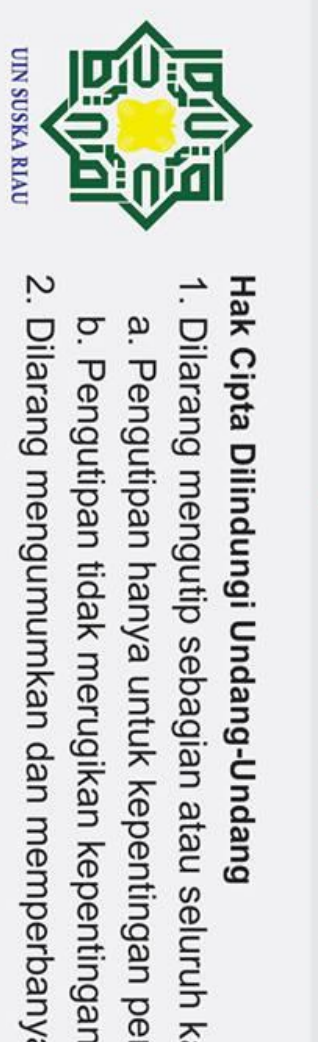

\begin{tabular}{|c|c|c|}
\hline 更 & & Unstandardized Residual \\
\hline 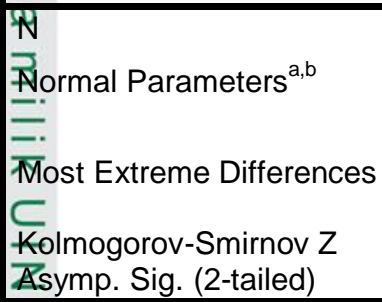 & $\begin{array}{l}\text { Mean } \\
\text { Std. Deviation } \\
\text { Absolute } \\
\text { Positive } \\
\text { Negative }\end{array}$ & $\begin{array}{r}25 \\
.0000000 \\
2.74399290 \\
.163 \\
.163 \\
-.120 \\
.814 \\
.521 \\
\end{array}$ \\
\hline
\end{tabular}

Asymp. Sig. (2-tailed)

a. Test distribution is Normal.

b. Calculated from data.

()

a)

b. Multikolinearitas

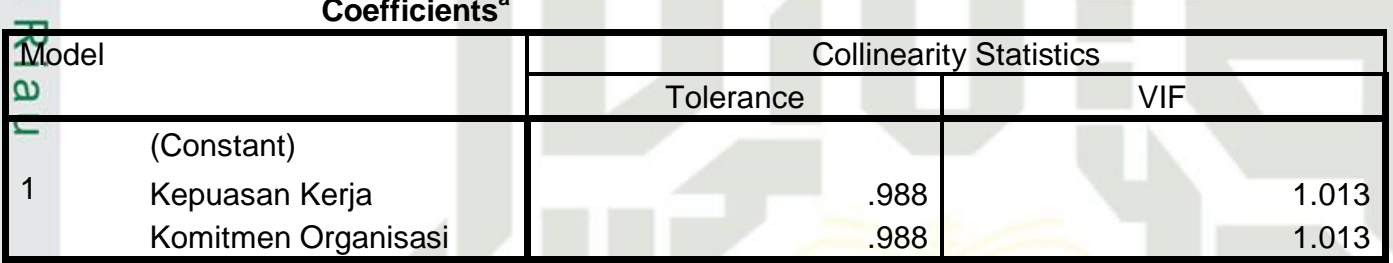

a. Dependent Variable: Kinerja

\section{c. Heteroskedastisitas}

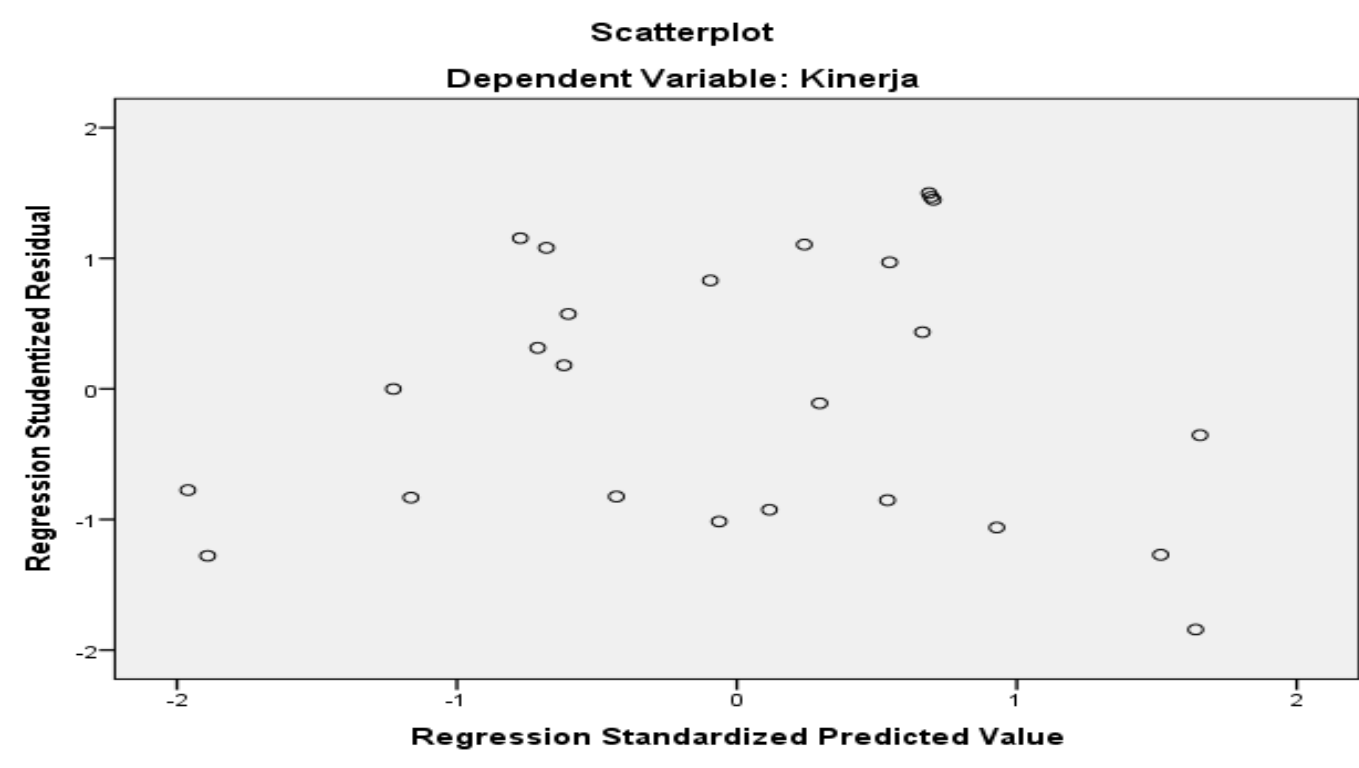




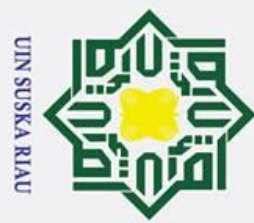

3. Analisis Regresi Linier Berganda

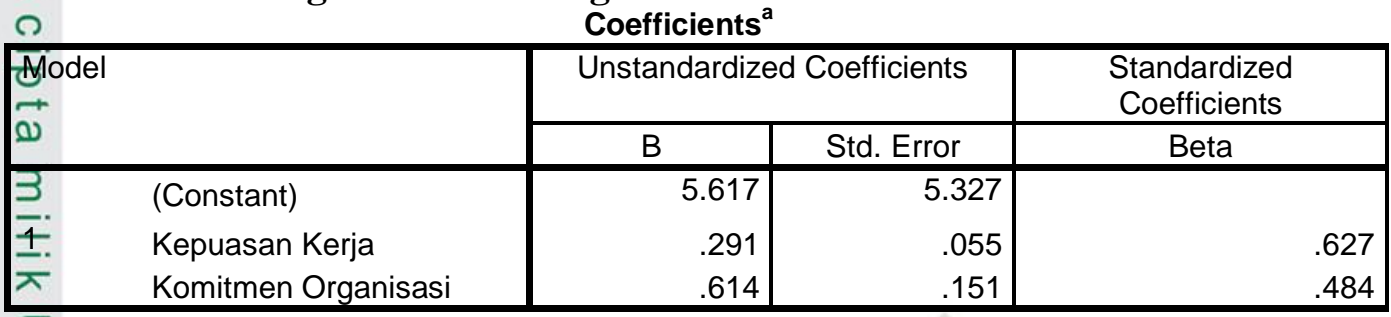

a.Dependent Variable: Kinerja

\section{Uji Hipotesis}

a. Uji Parsial (T)

Coefficients $^{a}$

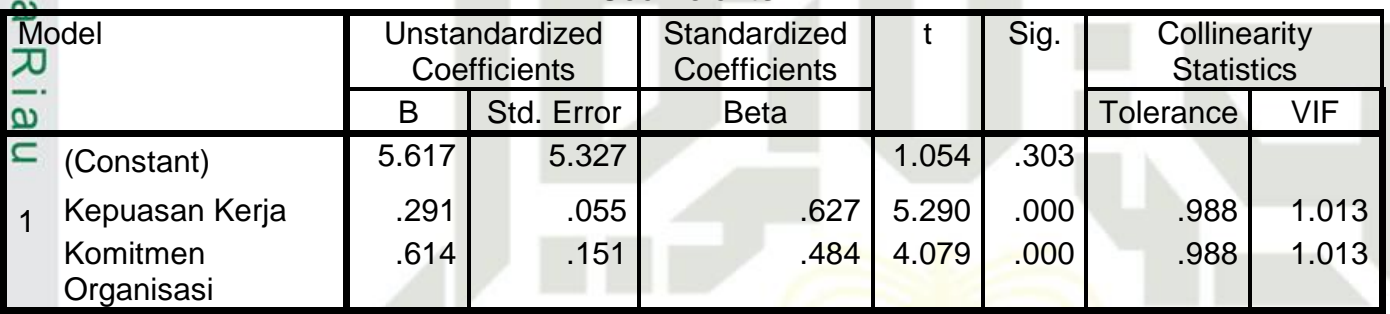

a. Dependent Variable: Kinerja

\section{b. Uji Simultan (F)}

\begin{tabular}{|ll|r|r|r|r|r|}
\hline Model & & Sum of Squares & \multicolumn{1}{|c|}{ df } & Mean Square & F & Sig. \\
\hline \multirow{2}{*}{1} & Regression & 411.132 & 2 & 205.566 & 25.026 & $.000^{\circ}$ \\
& Residual & 180.708 & 22 & 8.214 & & \\
& Total & 591.840 & 24 & & & \\
\hline
\end{tabular}

a. Dependent Variable: Kinerja

b. Predictors: (Constant), Komitmen Organisasi, Kepuasan Kerja

:

के

c. Uji Koefisien Determinasi $\left(\mathbf{R}^{2}\right)$

$\rightarrow$

Model Summary ${ }^{\mathrm{b}}$

\begin{tabular}{|l|r|r|r|r|r|}
\hline Model & \multicolumn{1}{|c|}{$\mathrm{R}$} & $\mathrm{R}$ Square & \multicolumn{1}{c|}{$\begin{array}{c}\text { Adjusted } \mathrm{R} \\
\text { Square }\end{array}$} & $\begin{array}{c}\text { Std. Error of the } \\
\text { Estimate }\end{array}$ & Durbin-Watson \\
\hline S. & $.833^{\mathrm{a}}$ & .695 & .667 & 2.866 & 1.367 \\
\hline
\end{tabular}

a. Predictors: (Constant), Komitmen Organisasi, Kepuasan Kerja

b. Dependent Variable: Kinerja

\section{Frekuensi}

a. Kinerja

Y.1

\begin{tabular}{|c|c|c|c|c|c|}
\hline 0 & & Frequency & Percent & Valid Percent & Cumulative Percent \\
\hline co & 3 & 3 & 12.0 & 12.0 & 12.0 \\
\hline E & 4 & 11 & 44.0 & 44.0 & 56.0 \\
\hline$\forall$ valid & 5 & 11 & 44.0 & 44.0 & 100.0 \\
\hline 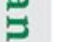 & Total & 25 & 100.0 & 100.0 & \\
\hline
\end{tabular}



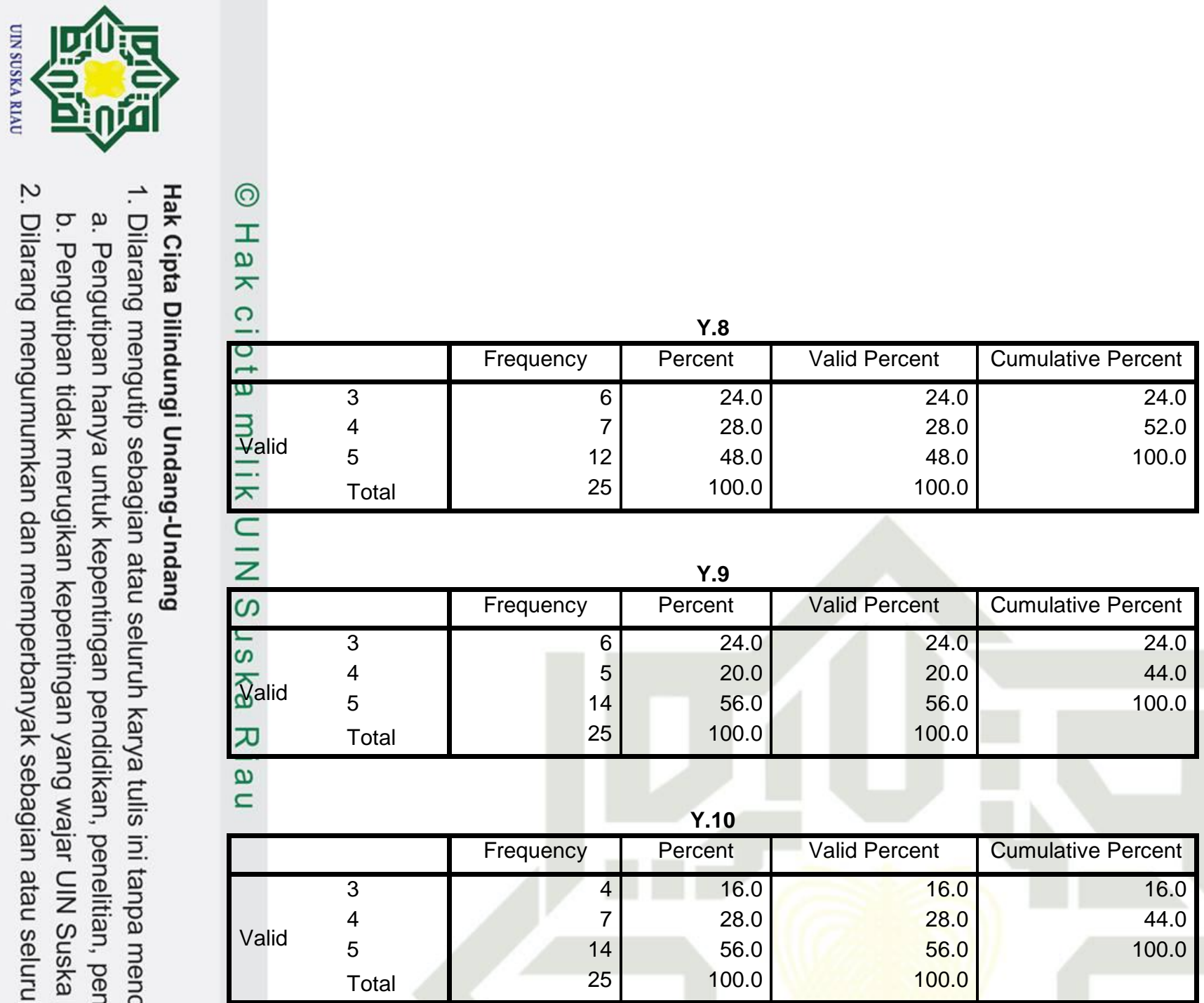

b. Kepuasan Kerja

X1.1

\begin{tabular}{|c|c|c|c|c|c|}
\hline & & Frequency & Percent & Valid Percent & Cumulative Percent \\
\hline $\begin{array}{l}\frac{\pi}{\text { Valid }} \\
\frac{1}{0}\end{array}$ & $\begin{array}{l}3 \\
4 \\
5 \\
\text { Total }\end{array}$ & $\begin{array}{r}5 \\
6 \\
14 \\
25\end{array}$ & $\begin{array}{r}20.0 \\
24.0 \\
56.0 \\
100.0\end{array}$ & $\begin{array}{r}20.0 \\
24.0 \\
56.0 \\
100.0\end{array}$ & $\begin{array}{r}20.0 \\
44.0 \\
100.0\end{array}$ \\
\hline $\begin{array}{l}\infty \\
D \\
B\end{array}$ & & & $\mathrm{X} 1.2$ & & \\
\hline $\overrightarrow{0}^{\circ}$ & & Frequency & Percent & Valid Percent & Cumulative Percent \\
\hline 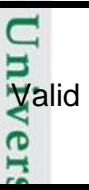 & $\begin{array}{l}3 \\
4 \\
5 \\
\text { Total }\end{array}$ & $\begin{array}{r}6 \\
7 \\
12 \\
25\end{array}$ & $\begin{array}{r}24.0 \\
28.0 \\
48.0 \\
100.0\end{array}$ & \begin{tabular}{r|}
24.0 \\
28.0 \\
48.0 \\
100.0
\end{tabular} & $\begin{array}{r}24.0 \\
52.0 \\
100.0 \\
\end{array}$ \\
\hline $\begin{array}{l}\vec{Z}: \\
\overrightarrow{4} \\
0 \\
0\end{array}$ & & & $\mathbf{X} 1.3$ & & \\
\hline in & & Frequency & Percent & Valid Percent & Cumulative Percent \\
\hline $\begin{array}{l} \pm \\
\square \\
\forall \text { alid } \\
\infty \\
\infty\end{array}$ & $\begin{array}{l}2 \\
3 \\
4 \\
5 \\
\text { Total }\end{array}$ & $\begin{array}{r}1 \\
5 \\
7 \\
12 \\
25\end{array}$ & $\begin{array}{r}4.0 \\
20.0 \\
28.0 \\
48.0 \\
100.0\end{array}$ & $\begin{array}{r}4.0 \\
20.0 \\
28.0 \\
48.0 \\
100.0\end{array}$ & $\begin{array}{r}4.0 \\
24.0 \\
52.0 \\
100.0\end{array}$ \\
\hline
\end{tabular}




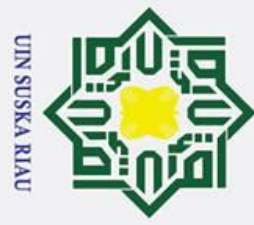

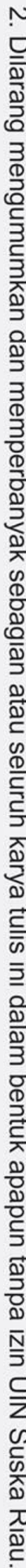

\begin{tabular}{|c|c|c|c|c|c|}
\hline$\tilde{\sim}$ & & Frequency & Percent & Valid Percent & Cumulative Percent \\
\hline$\Phi$ & 2 & 1 & 4.0 & $\overline{4.0}$ & $\overline{4.0}$ \\
\hline 3 & 3 & 6 & 24.0 & 24.0 & 28.0 \\
\hline Valid & 4 & 7 & 28.0 & 28.0 & 56.0 \\
\hline$\pi$ & 5 & 11 & 44.0 & 44.0 & 100.0 \\
\hline$\subset$ & Total & 25 & 100.0 & 100.0 & \\
\hline
\end{tabular}

듯 읏

$\mathrm{X} 1.5$

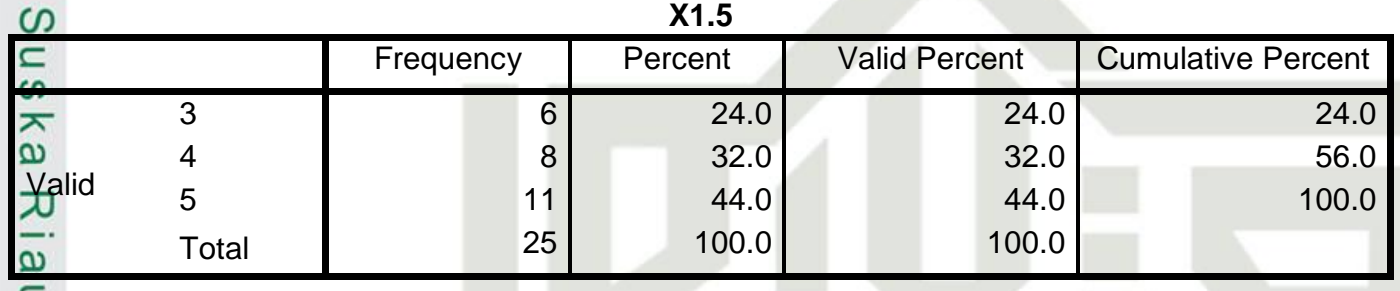

X1.6

\begin{tabular}{|c|c|c|c|c|c|}
\hline & & Frequency & Percent & Valid Percent & Cumulative Percent \\
\hline \multirow{5}{*}{ Valid } & 2 & 1 & 4.0 & 4.0 & 4.0 \\
\hline & 3 & 5 & 20.0 & 20.0 & 24.0 \\
\hline & 4 & 10 & 40.0 & 40.0 & 64.0 \\
\hline & 5 & 9 & 36.0 & 36.0 & 100.0 \\
\hline & Total & 25 & 100.0 & 100.0 & \\
\hline
\end{tabular}

X1.7

\begin{tabular}{|ll|r|r|r|r|}
\hline & & Frequency & Percent & Valid Percent & Cumulative Percent \\
\hline W & 3 & 7 & 28.0 & 28.0 & 28.0 \\
Vyalid & 4 & 10 & 40.0 & 40.0 & 68.0 \\
D & 5 & 8 & 32.0 & 32.0 & 100.0 \\
\hline & Total & 25 & 100.0 & 100.0 & \\
\hline
\end{tabular}

X1.8

\begin{tabular}{|c|c|c|c|c|c|}
\hline \multicolumn{2}{|l|}{$\bar{n}^{\circ}$} & Frequency & Percent & Valid Percent & Cumulative Percent \\
\hline$c$ & 3 & 7 & 28.0 & 28.0 & 28.0 \\
\hline E. & 4 & 7 & 28.0 & 28.0 & 56.0 \\
\hline 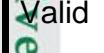 & 5 & 11 & 44.0 & 44.0 & 100.0 \\
\hline 营 & Total & 25 & $\begin{array}{r}700.0 \\
\end{array}$ & 100.0 & $\pi$ \\
\hline
\end{tabular}

X1.9

\begin{tabular}{|c|c|c|c|c|c|}
\hline$\infty$ & & Frequency & Percent & Valid Percent & Cumulative Percent \\
\hline$E$ & 3 & 5 & 20.0 & 20.0 & 20.0 \\
\hline 7 & 4 & 11 & 44.0 & 44.0 & 64.0 \\
\hline Valid & 5 & 9 & 36.0 & 36.0 & 100.0 \\
\hline$\omega$ & Total & 25 & 100.0 & 100.0 & \\
\hline
\end{tabular}



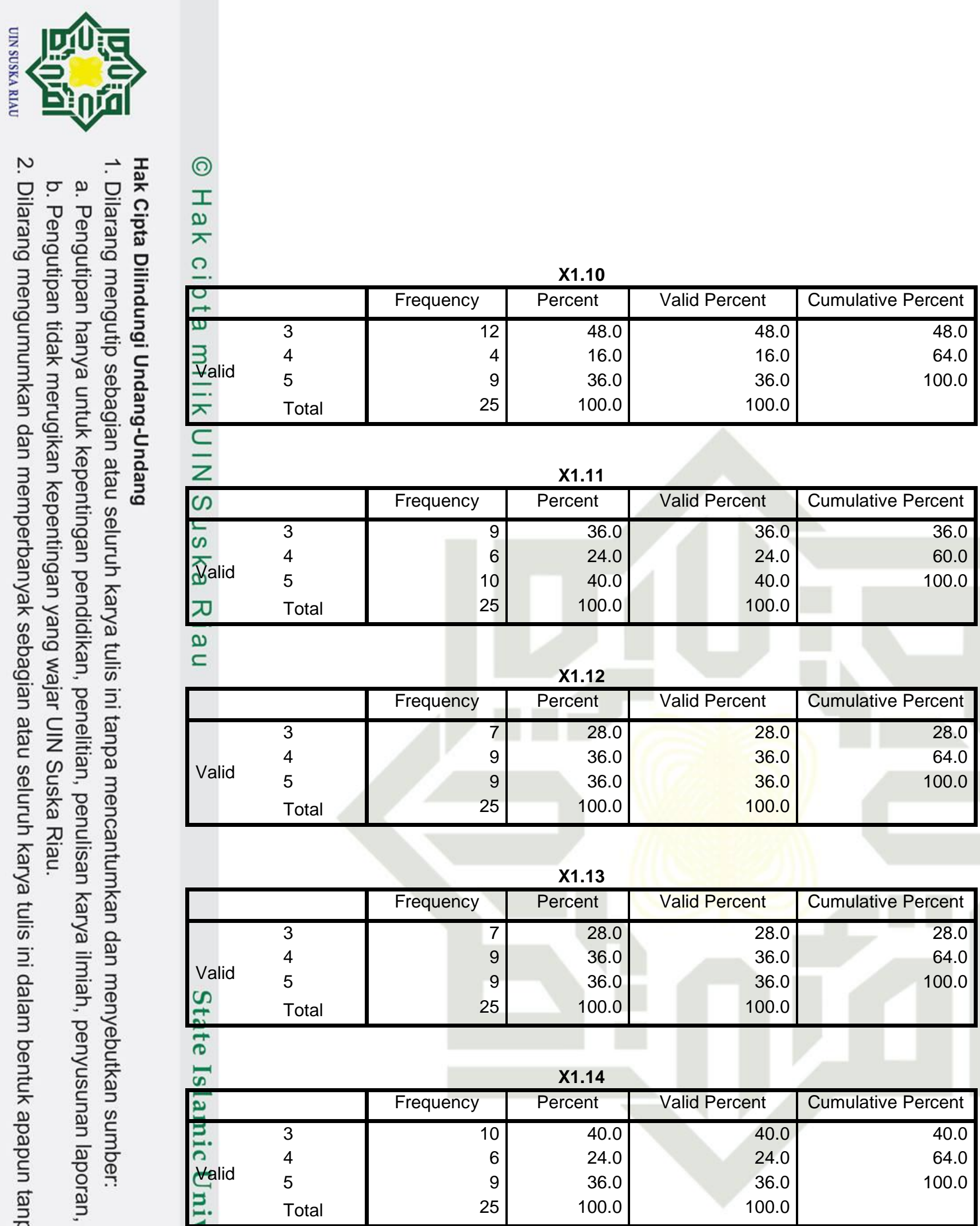

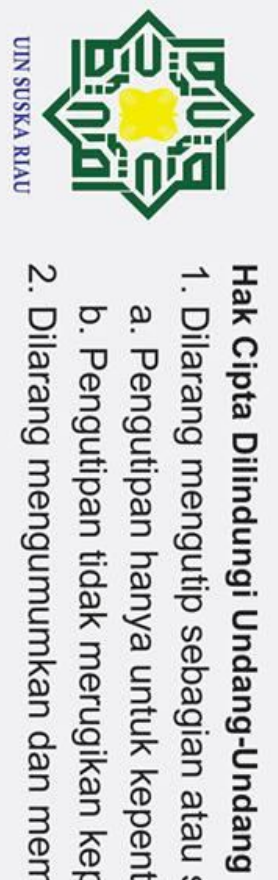

()

$\Omega$

\begin{tabular}{|c|c|c|c|c|c|}
\hline \multicolumn{6}{|c|}{$\begin{array}{r}\mathrm{X} 1.15 \\
\end{array}$} \\
\hline$\underset{+}{+}$ & & Frequency & Percent & Valid Percent & Cumulative Percent \\
\hline W & 2 & 1 & 4.0 & 4.0 & 4.0 \\
\hline 3 & 3 & 5 & 20.0 & 20.0 & 24.0 \\
\hline Valid & 4 & 10 & 40.0 & 40.0 & 64.0 \\
\hline $\bar{\pi}$ & 5 & 9 & 36.0 & 36.0 & 100.0 \\
\hline$\subset$ & Total & 25 & 100.0 & 100.0 & \\
\hline
\end{tabular}

$\begin{array}{ll}Z & \\ \infty & X 1.16\end{array}$

\begin{tabular}{|c|c|c|c|c|c|}
\hline ᄃ & & Frequency & Percent & Valid Percent & Cumulative Percent \\
\hline$\pi$ & 3 & $\overline{6}$ & 24.0 & 24.0 & 24.0 \\
\hline (a) & 4 & 10 & 40.0 & 40.0 & 64.0 \\
\hline Yalid & 5 & 9 & 36.0 & 36.0 & 100.0 \\
\hline $\overrightarrow{0}$ & Total & 25 & 100.0 & 100.0 & \\
\hline
\end{tabular}

X1.17

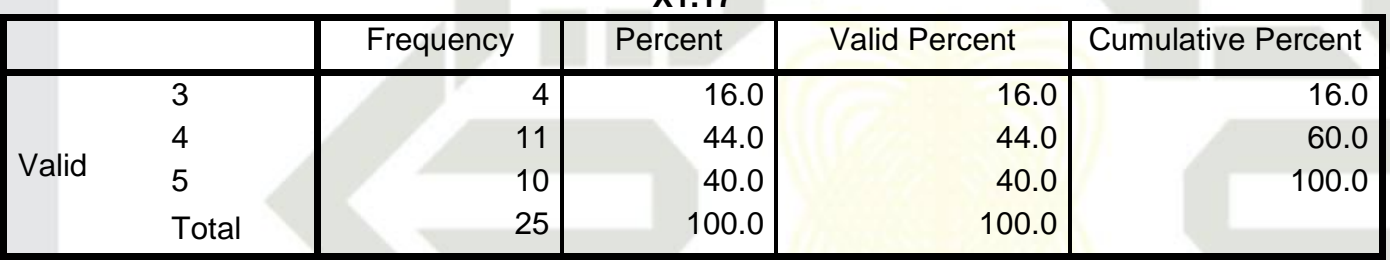

$\mathrm{X} 1.18$

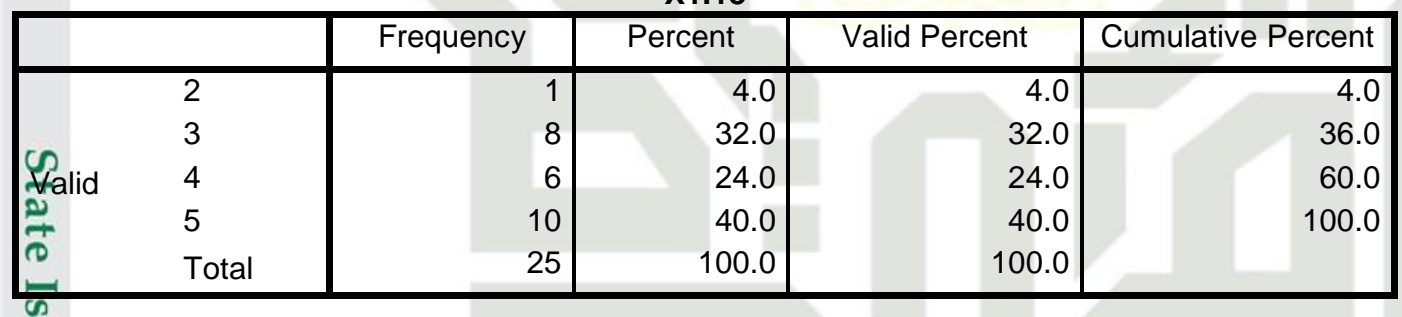

X1.19

\begin{tabular}{|c|c|c|c|c|c|}
\hline م" & & Frequency & Percent & Valid Percent & Cumulative Percent \\
\hline $\bar{c}$ & 3 & 10 & 40.0 & 40.0 & 40.0 \\
\hline Z. & 4 & 5 & 20.0 & 20.0 & 60.0 \\
\hline$\left.\right|_{0} ^{\text {yalid }}$ & 5 & 10 & 40.0 & 40.0 & 100.0 \\
\hline 常 & Total & 25 & 100.0 & 100.0 & $\pi$ \\
\hline
\end{tabular}



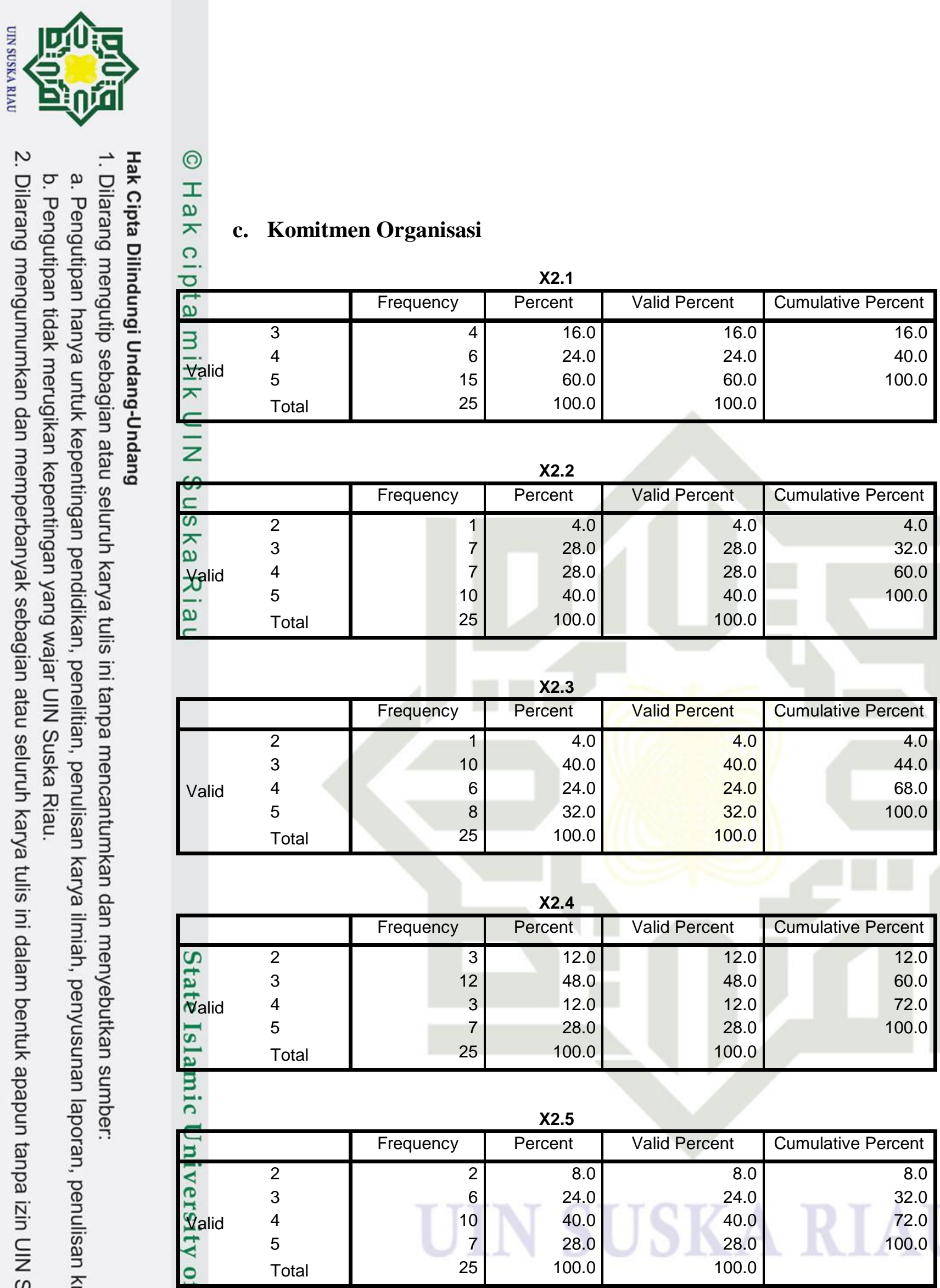


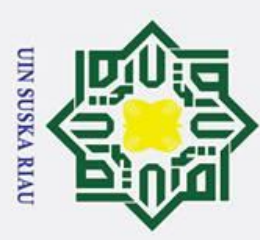

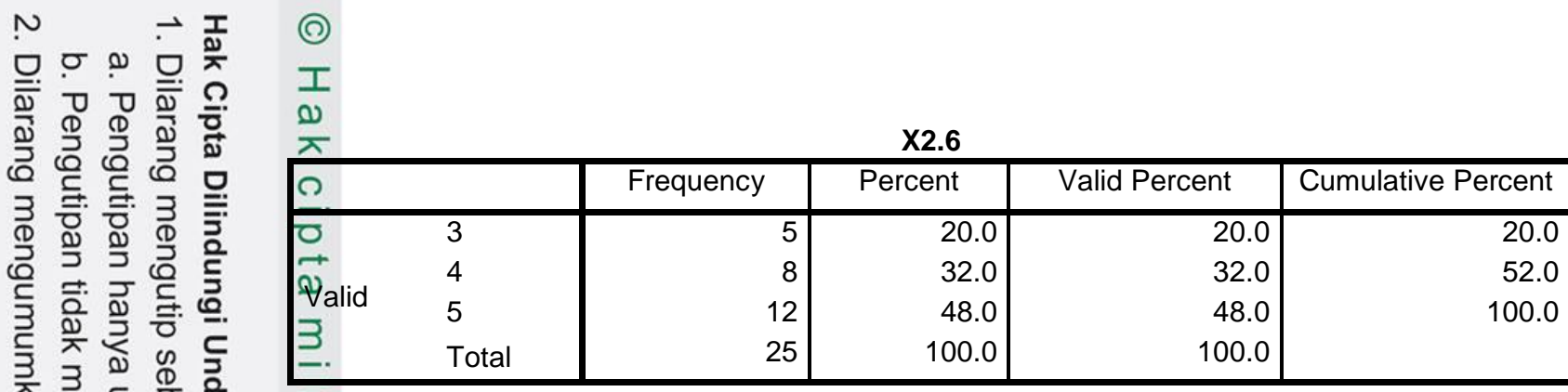

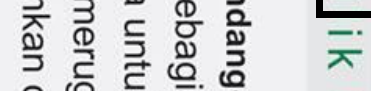

응 흧. 둣 음 붕

党 离

更

市壳

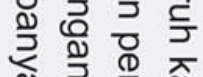

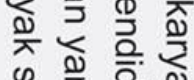

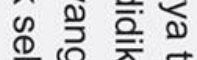

恼 离

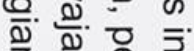

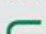

$\frac{c}{z}$

()

$\frac{c}{c}$

$\pi$

(1)

D

ㅁ.

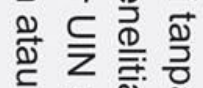

क ल

里

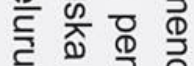

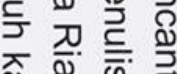

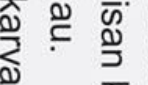

드. 젱

इ. ฏे ฏे

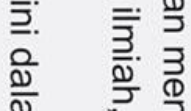

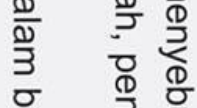

ए

$\frac{2}{2}$

$\infty$

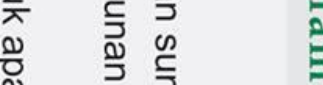

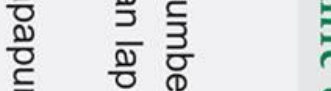

奇

 

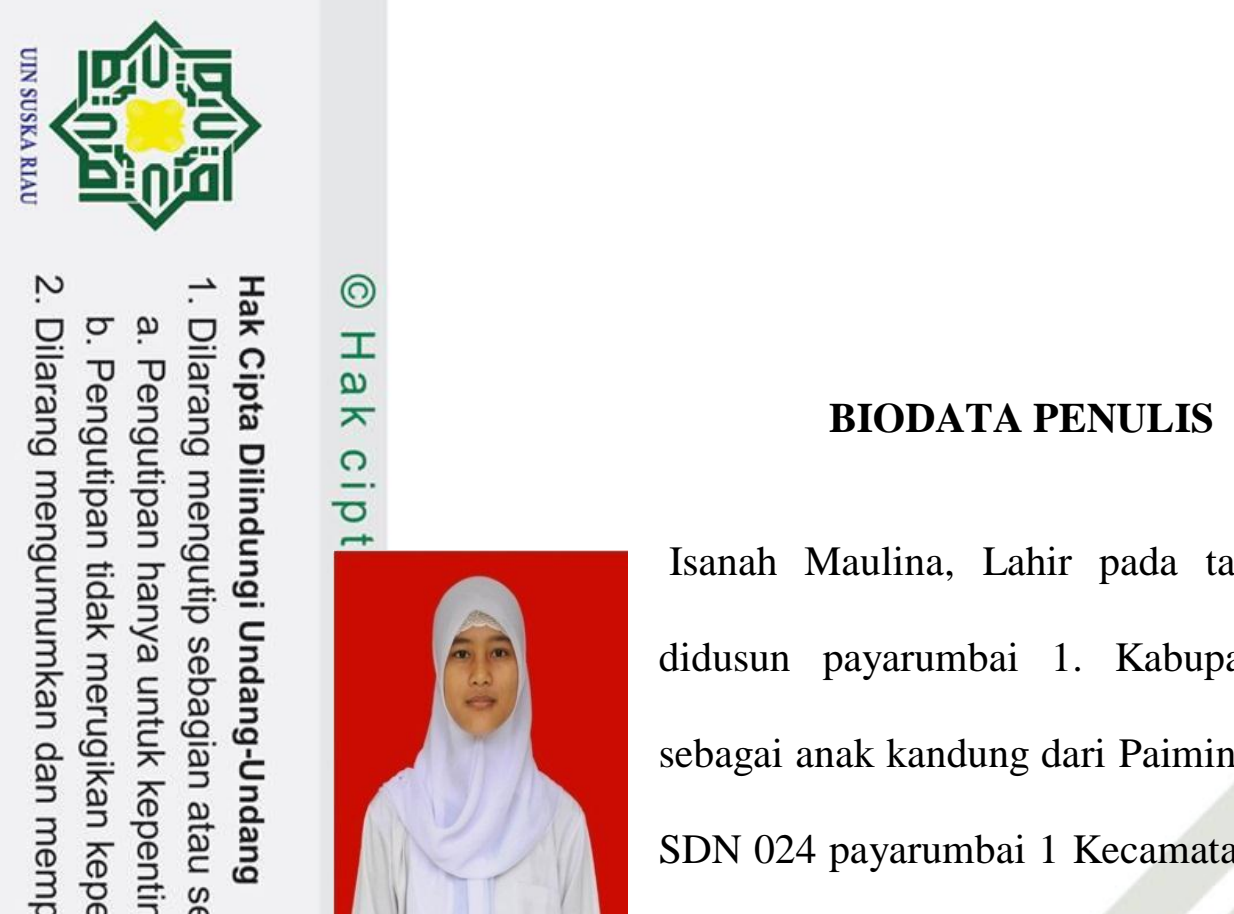

Isanah Maulina, Lahir pada tanggal 15 November 1995 didusun payarumbai 1. Kabupaten Indragirihulu Terlahir sebagai anak kandung dari Paimin dan Giyarni Bersekolah Di SDN 024 payarumbai 1 Kecamatan,Rengat Barat SMP Negeri 3̊Tanah Datar dan SMK Negeri 1 Rengat. Kabupaten Indragirihulu Provinsi Riau. $\pi$ Kemudian Masuk UIN SUSKA Riau dan Mendapat gelar Sarjana Ekonomi (SE). M̂̀ langkah yang saya lakukan. Mempeunyai banyak cita - cita serta harapan yang semoga saja terwujud dan bersyukur kepada Allah SWT dilahirkan dalam agama yang mulia, Agama Islam

--- Enthusiasm is the mother of effort and without it nothing great was ever achieved ( Rafph Waldo Emerson) 